\title{
Nationality and Human Rights: The Protection of the Individual in External Arenas*
}

\author{
Myres S. McDougal, $*$ Harold D. Lasswell*** \\ and Lung-chu Chen $* * *$
}

\section{TABLE OF CONTENTS}

I. Delimitation of the Problem

II. The Glarification of General Community Policy

III. Trends in Decision and Conditioning Factors

A. Claims by the Individual to a Protecting State 906

B. Claims Relating to the Conferment of Nationality 918

C. Claims Relating to the Withdrawal of Nationality 928

1. Voluntary Expatriation 928

2. Withdrawal with Consent (Genuine or Constructive) for Promoting Harmonious Relations Between States

3. Withdrawal Without Consent as Punishment

D. Claims Relating to Statelessness 960

1. Minimization of Statelessness 965

a. Statelessness at Birth 967

b. Statelessness Subsequent to Birth 970

2. Mitigations of Statelessness 976

E. Claims Relating to Multiple Nationality 981

IV. Appraisal and Recommendations 993

* This article is excerpted from a book which the authors have in progress. The authors are indebted to their colleagues, W. Michael Reisman and Arie David, for suggestions and critical assistance in the preparation of this article. The Ralph E. Ogden Foundation has been generous in its support of the studies from which this article is drawn.

* Sterling Professor of Law, Yale Law School.

*** Ford Foundation Professor of Law and Social Sciences, Emeritus, Yale Law School.

*:*:* Senior Research Associate, Yale Law School. 


\section{Delimitation of the Problem}

In a world of ever-increasing transnational interaction the importance to individuals of protection within transnational processes of authoritative decision correspondingly increases. The claims with which we are concerned here are those by an individual for membership in a territorial community for the purposes both of obtaining external protection against other territorial communities and of securing richer participation in the value processes of his chosen community and the world community. The traditional linkage of the individual with territorial communities for such purposes has been through the concept of nationality. ${ }^{1}$ Individuals are said to be the "nationals" of a state when that state asserts, and the larger world community honors, claims to protect and control such individuals for all the comprehensive purposes of states, as contrasted with occasional particular exercises of competence under varying principles of jurisdiction. ${ }^{2}$

It is, thus, of critical importance how the concept of "nationality" and all the ancillary rules about the conferment and withdrawal of nationality are managed in the allocation of competence among terri-

1. On nationality see generally Nationaliry Laws (R. Flournoy \& M. Hudson eds. 1929) [hereinafter cited as R. Flournoy \& M. Hudson]; United Nations Legislative Series, LAws CoNCERning Nationality, U.N. Doc. ST/LEG/SER. B/4 (1954), and SupplemeN! to Laws Concerning Nationality, U.N. Doc. ST/LEG/SER. B/9 (1959); H. VAN PaNiuys, The Role of Natiónality in International Law (1959); P. Weis, Nationality AND Statelessness In International LaW (1956); Brownlie, The Relations of Nationality in Public International Law, 39 BRIT. Y.B. INT'L L. 284 (1965); Harvard Research in International Law, The Law of Nationality, 23 AM. J. INT'L L. Supp. 11 (1929) [hereinafter cited as Harvard Research]; Hudson, Report on Nationality, Including Statelessness, [1952] 2 Y.B. INT'L L. CoMM'N 3-24, U.N. Doc. A/CN.4/50 (1958); Silving, Nationality in Comparative Law, 5 AM. J. Comp. L. 410 (1956). See also S. Greenleigh \& R. Margenau, The International Law of Nationality: A Policy-Oriented Inquiry, 1962 (unpublished student paper in Yale Law School Library); C. Liu, The Control of People as a Base of Power: International Law of Nationality and Access to Territory, 1957 (unpublished J.S.D. dissertation in Yale Law School Library). The authors have found the study by Messrs. Greenleigh and Margenau particularly helpful.

2. The concept of "nationality" is often reified into a pseudo-absolute comparable to "title." The concept, in fact, serves as a chameleon-like term for making ambiguous references to facts, claims, relevant policies, and legal consequences. The facts embrace many differing degrees of membership in one or more groups; the claims are made by both states and individuals; the relevant policies vary with a great range of practical problems; and legal consequences are commonly fashioned to serve both inclusive and exclusive policies as problems vary.

The pervasive ambiguity in the concept can be escaped only by keeping entirely distinct at least the following:

(1) the facts in global social process which comprise both "group memberships" and the interactions of individuals across nation-state lines;

(2) the claims that nation-states make, under their varying national laws, to protect, control, and impose burdens upon individuals;

(3) the policies of a transnational law which seek to protect both the human rights of individuals and the common interests of states; and

(4) the decisions taken in transnational arenas of authority in regulation of the claims of both states and individuals about protection, control, and burdens.

The flexibilities of the concept of "citizenship" are indicated in Bickel, Citizenship in the American Constitution, 15 ARIz. L. REv. 369 (1973). 
torial communities to protect individual human beings against deprivations by other territorial communities and in determinations of what states are authorized to impose what burdens upon individuals in different value processes. In a world arena still largely state-organized, decisions about nationality may affect both the degree to which the individual person has access to a protector and the substantive content of his rights. It is a distinguishing characteristic of nation-states that they claim a special competence to impose upon their members unique burdens with respect, for example, to taxation, military service, and subjection to civil and criminal jurisdiction; how these burdens are distributed, and maximized or minimized, through assertion by one or more states, importantly affects the aggregate enjoyment of human rights by individuals.

The central focus of our present inquiry is upon the allocation of competence to protect individuals and the decisions which most directly affect this allocation. Given a decentralized world arena in which nation-states are still the principal official participants, if the individual human being does not have some state as a protector, the larger community aspiration for human rights is meaningless. Thus, the stateless person-the person without formal membership in any body politic-is treated as an international outcast, an "unprotected person." 3 The possible value deprivations to which such a person may be subjected are severe and all-encompassing, far beyond those common to aliens; he has little or no access to authoritative decision, on either national or international levels. Similarly, the individual who is confronted with administrative obstacles or legal complexities in establishing a nationality, whose acknowledged state refuses to protect him, or who is denied a claim against a state of his nationality may be made equally to suffer a deprivation of human rights in the merits of his claim.

The practices of states in conferring or withholding nationality and the procedures established by states for such conferment or withholding may of course directly affect not only access to a protector but also the quantity and quality of participation in all value processes, both national and international. Hence significant inquiry about actual and potential deprivations of human rights must make detailed examination of the flow of decision about practices and procedures in the conferment and withholding of nationality.

3. For further elaboration, see pp. 960-62 infra. 
Individuals who, in contrast with the stateless person, are claimed by more than one state-i.e., who have multiple nationality-may sometimes enjoy the advantages of greater protection. They may also, however, be held subject to greater responsibilities and be subjected to greater burdens. Thus, they may be in danger of multiple jeopardy in terms of military service, taxation, and subjection to jurisdiction.

The more detailed claims to authoritative decision with which we are here concerned may, hence, be summarized as follows:

(1) claims by the individual to a protecting state;

(2) claims relating to the conferment of nationality;

(3) claims relating to the withdrawal of nationality (including voluntary expatriation);

(4) claims relating to statelessness; and

(5) claims relating to multiple nationality.

\section{The Clarification of General Community Policy}

Historically, in the allocation of competence over peoples the established decisionmakers of the transnational community have honored, in varying combinations in different contexts, two complementary policies. One policy, most preferred when expectations of large-scale violence are low, favors human rights and encourages freedom in the circulation of people and easy changes in group membership, much the same as it encourages freedom of movement in capital, goods, services, and ideas. The other policy, especially stressed under conditions of continuing expectations of imminent violence, concedes more to the interests of states in the exclusive protection of their bases of power, through stringent controls over people, including restrictions upon change of national membership.

The long-term policy most compatible with an international law of human dignity would be one that seeks the utmost voluntarism in affiliation, participation, and movement, with an easy assumption by states of a competence to protect such individuals as seek their protection. The individual should be able to become a member of, and to participate in the value processes of, as many bodies politic as his capabilities will permit.

It must of course be conceded that, given the present structure of the world arena, states do share some common interests which may on occasion require limitation of this preferred policy of the utmost individual voluntarism. Despite contemporary technological develop- 
ments, people remain an important base of power for each of the different territorially organized communities of the world. Both the security, in the minimum sense of freedom from external violence and coercion, and the quality of society, in terms of the greater production and wider sharing of all values, that a community can achieve are intimately dependent upon the numbers and characteristics of its members, including their capabilities, skills, and loyalties. It is this intimate dependence which is reflected in the historic reciprocal honoring of the principles of $j u s$ soli and jus sanguinis in the allocation of members and of the principles of "territoriality" and "nationality" in the allocation of jurisdiction. Secondarily, territorial communities share important interests in maintaining harmonious relationships among themselves and in avoiding situations of potential conflict in their claims about members. The different communities have, finally, a common interest in a certain economy in the expenditure of resources in their practices for the allocation of members and the provision of protection in transnational processes of authoritative decision.

The task of a decisionmaker or other evaluator who genuinely identifies with the whole community of mankind is that of achieving an accommodation in particular instances between the complementary policies reflected in the demands of states and the demands of individuals, an accommodation which will best promote in the long run the largest net, aggregate achievement of human rights.

In search of such accommodation, a strong preference might be given policies which accord to every individual the protection of at least one state for the purpose of securing within transnational processes of authoritative decision a proper hearing upon the merits of controversies. Thus, to make certain that individuals have at least one nationality for this purpose, access to community membership upon both jus soli and jus sanguinis, and even upon the simple request of the individual, might be authorized in the most generous degree.

From broader human dignity perspectives the individual's volition should be accorded the utmost possible expression and respect in all the different decisions concerning nationality: the conferment of nationality, the procedures by which nationality is established and evidenced, the withdrawal of nationality, the minimization and amelioration of statelessness, and the regulation of multiple nationality. In particular, states should not be permitted to make arbitrary 
conferment (that is, upon grounds unrelated to common interest) of nationality against the wishes of the individual. Nor should states be permitted arbitrarily to deny (as for purposes of discrimination) nationality sought by the individual.

Save for conflict with the most urgent state necessities, people ought thus to be allowed freely to determine their nationality subsequent to birth. Their wishes should be made largely the decisive factor, with only a modest deference toward criteria designed to protect state interests. In support of these policies procedures for establishing and withdrawing nationality should not be honored when they are so arbitrary as to negate whatever protection may otherwise be provided for the individual. Requirements for establishing and proving nationality need not, in order to preclude fraud, be so strict as to make compliance impossible. For the further protection of private choice, comparable policies might be recognized for the withdrawal of nationality. States should not be permitted arbitrarily (as for purposes of discrimination or punishment) to withdraw nationality, nor arbitrarily to preclude voluntary change of nationality. Statelessness should, by some one of many expedients, be abolished.

In keeping with the policy of honoring utmost voluntarism, the individual might be authorized to choose membership in all the bodies politic for which he is able and willing to assume responsibility. Such multiplicity in choice requires, of course, the right to change one's nationality. Similarly, any state of which an individual is a member should be authorized to protect him against another state, even one of which he is also a national. Multiple nationality is to be preferred in contexts in which it increases the protection available for the individual; it should be rejected when it imposes arbitrary burdens upon him. In a public order of human dignity, the whole international law of nationality should, in sum, be designed for the better protection of the individual, with minimum concessions to the organized interests of the territorial communities.

\section{Trends in Decision and Conditioning Factors}

Decisions about every major type of claim which we have identified have, unhappily, expressed and been affected by perspectives, not of the fundamental rights of the individual, but of the paramount interests of state elites in the control of people as important bases of power. 


\section{A. Claims by the Individual to a Protecting State}

The overwhelming trend of decision has been to permit the state of nationality, and only the state of nationality, to protect individuals. ${ }^{4}$ Unfortunately, states are still regarded as having an option with respect to whether they will protect their nationals, for international law imposes no duty on the state to do so. Hence individuals are left to the arbitrary whim or caprice of state officials.

In addition, under the once dominant theory that states are the only "subjects" of international law, nation-states alone have been considered competent in most fora to present claims against other states. ${ }^{5}$ Injured individuals are denied access to transnational arenas to present claims against external entities; rather, they are made to look to their own state for protection against such value deprivations.

Similarly, the principle that a state can provide protection only in cases of deprivations suffered by its own nationals is well established. ${ }^{6}$ The only "link" generally accepted for purposes of establishing standing to protect against deprivations is, thus, that of nationality.

The fiction that sustains this inhibiting practice is that an injury to the individual is an injury to the state of his nationality. The classic thesis was expounded by Vattel:

4. The reference we make is to direct access to processes of authoritative decision. It does not escape our notice that many nonterritorial groups-ethnic, linguistic, skill, religious, for instance-effectively engage in vast and enduring patterns of protest and appraisal for the protection of the individual.

5. On the subject of diplomatic protection, the classics are E. Borchard, The Diplomatic Protection of Cirizens Abroad (1922), and F. Dunn, The Protection of Nationals (1932). See also L. Sohn \& R. Baxter, Convention on the International ReSPONSIBILITY OF STATES FOR INJURIEs to AliENS (1961); Harvard Research in International Law, The Law of Responsibility of States for Damage Done in Their Territory to the Person or Property of Foreigners, 23 AM. J. INT'L L. Supp. 131 (1929). Of special contemporary interest are a series of reports on international responsibility submitted to the International Law Commission, including, inter alia: First Report on International Responsibility, [1956] 2 Y.B. IN't' L. CoMm'N 173, U.N. Doc. A/CN. 4/96 (1956); Second Report on International Responsibility, [1957] 2 Y.B. INT'L L. COMM'N 104, U.N. Doc. A/CN. 4/106 (1957); Third Report on International Responsibility, [1958] 2 Y.B. INT'L L. Comm'N 47, U.N. Doc. A/CN. 4/111 (1958); Sixth Report on International Responsibility, [1961] 2 Y.B. INT'L L. COMM'N 1, U.N. DOC. A/CN. 4/134 and Add. 1 (1961). More recent commentaries include F. DAwSON \& I. HEAd, INTERNATIonal LAw, National Tribunals and the Rights of Aliens (1971); C. Joseph, Nationality and Diplomatic Protection (1969); R. Lillich \& G. Christenson, International Claims: Their Preparation ánd Presentation (1962); F. Vallat, International Law and the Practitioner (1966); Weis, Diplomatic Protection of Nationals and International Protection of Human Rights, 4 Human Righrs J. 643 (1971).

6. The Permanent Court of International Justice declared in the Mavrommatis Palestine Concessions Case:

It is an elementary principle of international law that a State is entitled to protect its subjects, when injured by acts contrary to international law committed by another State, from whom they have been unable to obtain satisfaction through the ordinary channels.

[1924] P.C.I.J., ser. A, No. 2, at 6, 12. 
Whoever ill-treats a citizen indirectly injures the State, which must protect that citizen. The sovereign of the injured citizen must avenge the deed and, if possible, force the aggressor to give full satisfaction or punish him, since otherwise the citizen will not obtain the chief end of civil society, which is protection. ${ }^{7}$

Similarly, the Permanent Court of International Justice in the Panevezys-Saldutiskis Railway Case observed that

in taking up the case of one of its nationals, by resorting to diplomatic action or international judicial proceedings on his behalf, a state is in reality asserting its own right, the right to ensure in the person of its nationals respect for the rules of international law. This right is necessarily limited to the intervention on behalf of its own nationals because, in the absence of a special agreement, it is the bond of nationality between the state and the individual which alone confers upon the state the right of diplomatic protection, and it is as a part of the function of diplomatic protection that the right to take up a claim and to ensure respect for the rules of international law must be envisaged. Where the injury was done to the national of some other State no claim to which such injury may give rise falls within the scope of the diplomatic protection which a State is entitled to afford nor can it give rise to a claim which that State is entitled to espouse. ${ }^{s}$

Under this fiction a state's right to protect is independent of the individual's interest; a state is put under no duty, but rather accorded complete discretion, to decide whether or not to press claims against external entities on behalf of its nationals. In most countries it is left to the executive branch, which may not be required to conform to judicial standards of due process, to decide. Given the overriding concern for the so-called "national" interest, nation-state elites tend to exaggerate, in the words of Frederick Dunn, "the importance of the political relations of states at the expense of the activities of men as human beings." Individuals' claims are put aside when the "national" interest so dictates. At times, therefore, the state interest, asserted from perspectives of the total foreign policy of the state, may be in contravention of the wishes of the individuals concerned.

Because of its negative implications for individual human rights and its manifest incompatibility with fact, this fiction has been under

7. 3 E. de Vattel. Classics of International Law: The Law of Nations or the Principles of Natural Law 136 (C. Fenwick transl. 1916).

8. Panevezys-Saldutiskis Railway Case, [1939] P.C.I.J., ser. A/B, No. 76, at 16.

9. Dunn, The International Rights of Individuals, [1941] ProceEdings, AM. Soc'y INT'L L. I4, 17. 
increasing attack. Thus, one commentator has pointed out that a deprivation to an individual is not necessarily a deprivation to the state and that the claim of the individual, not that of the state, is basic, a reality that is implied by the requirement for the exhaustion of local remedies by the individual. ${ }^{10}$ As stated by Umpire Parker of the United States-German Mixed Claims Commission,

[T]he generally accepted theory formulated by Vattel, which makes the injury to the national an injury to the nation and internationally therefore the claim a national claim which may and should be espoused by the nation injured, must not be permitted to obscure the realities or blind us to the fact that the ultimate object of asserting the claim is to provide reparation for the private claimant ....11

These perspectives demand a functional, rather than fictional, concept of protection. More fundamentally, of course, in an appropriately organized world the individual would be accorded competence to protect himself.

In specific application of the "nationality" myth, the doctrine of "continuous nationality" has for over a century resulted in the rejection of innumerable claims by arbitral tribunals. As developed under customary international law, a claimant must possess the nationality of the espousing state from the moment of deprivation, through the presentation of the claim, and often to the time of settlement. ${ }^{12}$ Thus, a claimant whose nationality is changed or lost after suffering a deprivation cannot obtain remedy. His state of nationality at the time of deprivation is precluded from espousing his claim because he is no longer its national; his new state of nationality is barred because at the time of injury he was not its national. In recent years the inequities caused by this requirement have been spotlighted by the post-war measures of wealth deprivation undertaken by the Eastern European countries. Large numbers of displaced people, who fled these countries during World War II and its aftermath, ${ }^{13}$ could derive no international succor under traditional doctrines of nationality.

10. "If the national State were directly injured its rights could hardly be contingent upon exhaustion of local remedies by the individual." 2 D. O'CoNNELL, INTERNATIONAL LAw 1031 (2d ed. 1970). Concerning the rule of exhaustion of local remedies, see E. Borchard, supra note 5, at 817-32; H. Briggs, The LAw of Nations $620-37$ (2d ed. 1952); L. SoHN \&. R. BAXTER, supra note 5, at 161:70.

11. Administrative Decision No. V (United States/Germany), 7 U.N.R.I.A.A. 119, 15253 (1956).

12. See R. Linlich \& G. Christenson, supra note 5, at 9-12; L. Sohn \& R. Baxter, supra note 5 , at 200-02.

13. See Kerley, Nationality of Claims-A Vista, [1969] Procendngs, AM. Soc'y Inr'ı L. $35,36$. 
The harsh effects of the doctrine are especially observable in connection with stateless persons and new immigrants, although mitigating measures are sometimes undertaken. For instance, during the nineteenth century, the United States made it a practice to afford protection to individuals on the basis of domicile plus a declaration of intent to become a United States citizen. ${ }^{14}$ This reflected in part the positive attitude toward immigration prevailing in the United States at the time and expressed and emphasized the significant ties other than nationality that a person may have with a territorial community. Occasionally, out of explicit humanitarian considerations, protection is afforded or at least asserted for other nonnationals, such as refugees or members of minority groups. This exception reinforces contemporary concern for human rights and for protection of refugees in particular. $^{15}$

Sometimes, in contrast, even the concept of "nationality" itself is questioned or distorted for the purpose of denying protection to individuals. Under contemporary international law, states are accorded a very broad competence for choosing among grounds for the conferment of nationality upon individuals and the practice of states exhibits a high degree of reciprocal deference to conferments of nationality in accordance with customary criteria. Yet upon occasion individuals have been deprived of a protector and of a hearing upon the merits of their claims either by invocation of variable or spurious conceptions of nationality or by imposition of tests over and beyond any traditional conception of nationality. The destructiveness for human rights of these decisions is dramatically illustrated in such famous cases as Nottebohm, ${ }^{16}$ Flegenheimer, ${ }^{17}$ and the Barcelona Traction Company. ${ }^{18}$ The importance to individuals of state protection in a state-organized world is such as to justify a somewhat detailed examination of these cases.

14. See Copithorne, International Claims and the Rule of Nationality, [1969] ProCEEDINGS, AM. Soc'y INT'L L. 30, 31.

15. On international protection of refugees, see UNITEd Nations Hich Commissioner for Refugees, A Mandate to Protect and Assist Refugees (1971). See also L. Holborn, The International Refugee Organization (1956); F. Norwood, Strangers and Exiles (1969); J. SchechtMan, The Refugee in the World (1963); J. Stoessinger, The Refugee and the World Comimunity (1956); J. Veranant, ThE Refugee in the Post-WaR WorLd (1953); Krenz, The Refugee as a Subject of International Law, 15 INT'L \& CoMP. L.Q. 90 (1966); Read, The United Nations and Refugees: Changing Concepts, 537 INT'L ConcIliation (1962); Rees, Century of the Homeless Man, 515 INT'L Conciliation (1957); Weis, The Concept of the Refugee in International Law, [1960] JOURNAL DU DROIT INTERNATIONAL 928; Weis, The International Protection of Refugees, 48 AM. J. INT'L L. 193,195 (1954).

16. Nottebohm Case, [1955] 1.C.J. 4.

17. Flegenheimer Claim, 25 I.L.R. 91 (Italian-United States Conciliation Commission 1963).

18. Case Concerning the Barcelona Traction, Light and Power Company, Limited, Second Phase, [1970] I.C.J. 4. 
In the Nottebohm case, ${ }^{19}$ involving Liechtenstein and Guatemala, the former sought restitution and compensation on behalf of one Friedrich Nottebohm for the latter's actions allegedly in violation of international law. A German national from his birth in Germany in 1881, Nottebohm moved to Guatemala in 1905, residing and doing business there, without ever applying for Guatemalan citizenship. Thereafter, he sometimes made trips to Germany to conduct business and to Liechtenstein to visit his brother, who lived there after 1931.

While still a German national Nottebohm applied for naturalization in Liechtenstein on October 9, 1939, shortly after the German invasion of Poland. Relieved of the three-year residence requirements, Nottebohm paid his fees and taxes to Liechtenstein and became a naturalized citizen of Liechtenstein by taking an oath of allegiance on October 20,1939 , thereby forfeiting his German nationality under the nationality law of Liechtenstein. He returned to Guatemala early in 1940 on a Liechtenstein passport to resume his business activities. At his request the Guatemalan Ministry of External Affairs changed the Nottebohm entry in its Register of Aliens from "German" to "Liechtenstein" national.

In July 1941, Nottebohm was blacklisted for trade purposes by the United States and his assets in the United States were frozen. Shortly afterward, on December 11, 1941, a state of war came into existence between the United States and Germany and between Guatemala and Germany. Arrested in Guatemala in October 1943, Nottebohm was deported to the United States, where he was interned as an enemy alien until 1946. Upon his release Nottebohm applied for readmission to Guatemala but was refused; therefore, he took up residence in Liechtenstein. Meanwhile, the Guatemalan government, after classifying him as an enemy alien, expropriated his extensive properties without compensation.

Liechtenstein instituted proceedings against Guatemala in the International Court of Justice, asking the court to declare that Guatemala had violated international law "in arresting, detaining, expelling and refusing to readmit $\mathrm{Mr}$. Nottebohm and in seizing and retaining his property."20 Guatemala's main contention was that Liechtenstein's claim was inadmissible because of Nottebohm's nationality. Liechtenstein's competence to protect Nottebohm was challenged. Guatemala argued that

19. [1955] I.C.J. 4.

20. Id. at 6-7. 
the Principality of Liechtenstein has failed to prove that $M$. Nottebohm, for whose protection it is acting, properly acquired Liechtenstein nationality in accordance with the law of the Principality; because, even if such proof were provided, the legal provisions which would have been applied cannot be regarded as in conformity with international law; and because M. Nottebohm appears in any event not to have lost, or not validly to have lost, his German nationality .....21

The court rejected the Liechtenstein claim by a vote of 11 to three, declaring that Nottebohm's naturalization could not be accorded international recognition because there was no sufficient "bond of attachment" between Nottebohm and Liechtenstein. Utilizing multiple nationality cases as precedents, the court expounded a "genuine link" theory of "real and effective nationality":

[A] State cannot claim that the rules it has thus laid down are entitled to recognition by another State unless it has acted in conformity with this general aim of making the legal bond of nationality accord with the individual's genuine connection with the State which assumes the defence of its citizens by means of protection as against other States. ... [N]ationality is a legal bond having as its basis a social fact of attachment, a genuine connection of existence, interests and sentiments, together with the existence of reciprocal rights and duties. It may be said to constitute the juridical expression of the fact that the individual upon whom it is conferred, either directly by the law or as the result of an act of the authorities, is in fact more closely connected with the population of the State conferring nationality than with that of any other State. ${ }^{22}$

The court concluded:

Naturalization was asked for not so much for the purpose of obtaining a legal recognition of Nottebohm's membership in fact in the population of Liechtenstein, as it was to enable him to substitute for his status as a national of a belligerent State that of a national of a neutral State, with the sole aim of thus coming within the protection of Liechtenstein but not of becoming wedded to its traditions, its interests, its way of life or of assuming the obligations-other than fiscal obligations- and exercising the rights pertaining to the status thus acquired. ${ }^{23}$

21. Id. at 9 .

22. Id. at 23 .

23. Id. at 26 . 
The Nottebohm decision has been widely criticized. ${ }^{24}$ It has nevertheless been invoked and applied to serve different purposes in different contexts. For present purposes, the application of the "genuine link" theory, borrowed from the very different context of dual nationality problems, has the unfortunate effect of depriving an individual of a hearing on the merits and the protection by a state willing to espouse his claim in the transnational arena. The net effect is an immense loss of protection of human rights for individuals. Such a decision runs counter to contemporary community expectations emphasizing the increased protection of human rights for individuals, especially the elimination of statelessness. As Judge Guggenheim stated emphatically in his dissenting opinion,

If the right of protection is abolished, it becomes impossible to consider the merits of certain claims alleging a violation of the rules of international law. If no other State is in a position to exercice [sic] diplomatic protection, as in the present case, claims put forward on behalf of an individual, whose nationality is disputed or held to be inoperative on the international level and who enjoys no other nationality, would have to be abandoned. The protection of the individual which is so precarious under existing international law would be weakened even further and I consider that this would be contrary to the basic principle embodied in Article 15(I) of the Universal Declaration of Human Rights adopted by the General Assembly of the United Nations on December 8th, 1948 , according to which everyone has the right to a nationality. Furthermore, refusal to exercise protection is not in accordance with the frequent attempts made at the present time to prevent the increase in the number of cases of stateless persons and to provide protection against acts violating the fundamental human rights recognized by international law as a minimum standard, without distinction as to nationality, religion or race. ${ }^{25}$

In the light of the foregoing, it is unfortunate that the drafters of the 1961 Harvard draft convention on state responsibility incorporated the Nottebohm doctrine and proposed that a "State is not entitled to present a claim on behalf of a natural person who is its national if that person lacks a genuine connection of sentiment, residence, or other interests with that State." ${ }^{26}$ Condoning unnecessary legalisms of im-

24. See, e.g., H. VAN Panhuys, supra note 1, at 95-105; De Visscher, L'Affaire Nottebohm, 27 ReVUe generale de proit INTERNational PUblic 238 (1956); Jones, The Nottebohm Case, 5 INT'L \& Comp. L.Q. 230 (1956); Kunz, The Nottebohm Judgment (Second Phase), 54 AM. J. INT'L L. 536 (1960).

25. Nottebohm Case, [1955] I.C.J. 4, 63-64.

26. L. SoHn \& R. BAXTER, supra note 5, at 199 (draft art. 23, para. 3).

To apply the Nottebohm doctrine to situations in which there exists only a "blood 
precise policy reference, which deny individuals a hearing upon the merits of their claims, can scarcely augment human rights.

While the Nottebohm decision denied the competence of Liechtenstein to protect a naturalized citizen, the Flegenheimer ${ }^{27}$ case involved the denial of protection to a national by birth. Paradoxically, Professor Sauser-Hall, defeated counsel for Liechtenstein in Nottebohm who presided over the Italian-United States Conciliation Commission in the Flegenheimer case, distinguished and rejected the Nottebohm decision in such a way as to augment, rather than mitigate, the inequities perpetrated in Nottebohm.

In the Flegenheimer case, Albert Flegenheimer sought invalidation of the 1941 sale of his stock in an Italian company, at a nominal sum, to which he assented because of his alleged fear of prevailing Italian anti-Semitic legislation and persecution. The Commission declared the petition filed on his behalf inadmissible on the ground that he was not a "United Nations national" within the scope of Article 78 of the Peace Treaty with Italy.

Albert's father, Samuel Flegenheimer, born in Baden, Germany, had moved to the United States in the 1860's and become a naturalized American citizen in 1873. In 1874, he returned to Germany to live in the then Kingdom of Wurttemberg, where Albert was born in 1890. On August 23, 1894, Samuel Flegenheimer was naturalized in Wurttemberg; and Albert, age 4, together with his brothers, was naturalized with his father. Not until 1933, when the Nazis attained power in Germany, was Albert Flegenheimer aware of his father's former American citizenship-and hence of the possibility of his own claim to such citizenship. Thereupon he approached American consulates and embassies in Europe to obtain a determination of his citizenship status, but his inquiries were answered either ambiguously or negatively.

In 1937, because of his fear of Nazi persecution, Albert Flegenheimer left Germany for Italy, Switzerland, and eventually Canada. On November 3, 1939, he formally submitted his claim to American citizenship at the United States Consulate in Winnipeg, Canada. In response later that month, the Board of Special Inquiry of the Immigration and Naturalization Service of the United States decided (erroneously, as later appeared) that he was not an American citizen. In

link" between a national and his state would deny hundreds of thousands of "overseas" nationals of China. France, and the United Kingdom the protection of their home government. Goldschmidt, Recent Applications of Domestic Nationality Laws by In. iernational Tribunals, 28 FoRDHAM L. REv. 689, 695 (1960).

27. Flegenheimer Claim, 25 I.L.R. 9I (Italian-United States Conciliation Commission 1963). See 53 AM. J. INT'L L. 944 (1959). 
April 1940, he was divested of German nationality by German decree. Subsequently, he took up residence in the United States in 1941-42 on a temporary visa. In February 1942, the Immigration and Naturalization Service acknowledged that Flegenheimer was an American citizen by birth. In October 1946, the Department of State, after an earlier refusal, granted him a United States passport. Subsequent to the commencement of proceedings before the Conciliation Commission, Flegenheimer was issued, on July 10, 1952, a certificate of United States nationality by the Acting Assistant Commissioner, Inspection and Examinations Division, Immigration and Naturalization Service of the United States.

By a unanimous decision the Conciliation Commission rejected the petition on behalf of Albert Flegenheimer, stating that though he "acquired by filiation the nationality of the United States, at birth, in Wurttemberg," he "acquired German and Wurttemberg nationality as the result of his naturalization in Wurttemberg on August 23, 1894, and thereby lost, after five years' residence in his new home country, his American nationality, under the Bancroft Treaty concluded on July 2, 1868, between the United States of America and Wurttemberg." 28 The Commission further found that Flegenheimer "never reacquired his American nationality after reaching majority" 20 and concluded that it was not bound by the certificate of American nationality of July $10,1952$.

In rejecting the validity of the certificate of United States nationality of July 10,1952, the Commission substituted its own evaluation of "nationality" for that of the United States. Clearly, in order to determine its jurisdiction, an international commission may investigate the nationality of parties on whose behalf claims are presented. However, the authorized scope of investigation is confined to establishing the facts pertinent to nationality and to appraisal of whether or not a state has exceeded accepted limits in its conferment of nationality. In the absence of claims by another state to the same individual or allegations that a state accords protection on the basis of spurious, fraudulent or impermissible grounds, the Commission is not authorized to substitute its own determination of nationality for that of a claimant state. This would appear the clear import of the Hague Convention on Nationality, which only makes customary international law explicit, when it stipulates that "[i]t is for each state to determine under its

28. 53 AM. J. INT'L L. 944, 945 (1959).

29. Id. 
own law who are its nationals" 30 and adds that "[a]ny question as to whether a person possesses the nationality of a particular state shall be determined by the laws of that state." 31 The one constraint established upon the discretion of states in conferring nationality is that such conferment is required to be recognized by other states only insofar as it is in accord with the traditional criteria of international law. ${ }^{32}$

By these commonly accepted criteria of international law the Commission might have been expected to honor the United States' authoritative determination that Flegenheimer was its national. The Commission adverted to no facts and to no policies which could give it authority to override the determination by the United States. There was no other state asserting a competing claim to Albert Flegenheimer as its national or offering to protect him. There was no suggestion, nor could one have been made, that any rule of international law would preclude the United States from recognizing Flegenheimer as its national. Even as against Wurttemberg the United States was an authoritative interpreter of any implied commitment it was alleged to have made about relinquishment of nationality. There was no suggestion that the United States' espousal of Flegenheimer's claim was in any way fraudulent or spurious. On the contrary, the United States obviously accepted Albert Flegenheimer in the fullest degree, and imposed obligation on him in the fullest degree, as citizen and national. Indeed, it did not appear that Flegenheimer's nationality could elsewhere be denied in any forum for any purpose.

It has thus been observed that it is "an unwarranted excess of power" 33 for the Commission to pry into the authoritative decisions of a claimant state so as to appraise the facts upon which the state has based its decision, and further to substitute its own evaluation for, and in negation of, the authoritative determination of the competent state officials. The net effect, as in Nottebohm, is denial of protection-of the minimum right to a hearing upon the merits-to the individual concerned.

The strangling technicalities of the "nationality" myth as applied to transnational business enterprises may also be employed to deprive individuals and groups of individuals of a protector which can secure appropriate hearings upon the merits of controversies. As the role of

30. The Convention on Certain Questions Relating to the Conflict of Nationality Laws of 1930, art. 1, 179 L.N.T.S. $89,99$.

31. Id. art. 2.

32. Id. art. 1 .

33. Goldschmidt, supra note 26 , at 714 . 
transnational enterprises becomes increasingly important, severe strains are placed upon the traditional doctrine affirming the nationality of claims. Based more or less on the doctrine of nationality applicable to individuals, the traditional doctrine attributes the competence to protect a corporate entity to the state under the laws of which it is incorporated and in whose territory it has its registered office. ${ }^{34}$ As with respect to individual human beings, however, the concept of the nationality of business entities is susceptible to manipulation in arbitrary ways. The Barcelona Traction case $^{35}$ is a dramatic recent illustration.

The Barcelona Traction, Light, and Power Company was incorporated in Toronto, Canada, in 1911, as a holding company for various wholly or substantially owned Spanish and Canadian subsidiaries, to develop and operate an electric power system in Spain. In 1948, a Spanish court declared it bankrupt and its assets were seized. As part of the company's unsuccessful efforts to resist the bankruptcy proceedings, the Belgian, British, Canadian, and United States govern. ments made representations to Spain on behalf of the company. For reasons not of record, the Canadian government ceased its diplomatic efforts on behalf of Barcelona Traction after 1955. Since Belgian nationals owned a large majority of the stock in the company, the Belgian government, after an earlier application to the court in 1958 and its subsequent withdrawal in 1961,36 brought this case before the International Court of Justice in 1962. The Spanish government raised four preliminary objections, two of which were rejected by the court in 1964; the other two were joined by the court on the merits. The court's final judgment, rendered in February 1970, upheld Spain's third preliminary objection, declaring that Belgium lacked standing (jus standi) to espouse a claim for its nationals, shareholders in a Canadian company, for damages allegedly resulting from illegal acts of various organs of the Spanish government against the company. Bel-

34. Case Concerning the Barcelona Traction, Light and Power Company, Limited, Second Phase, [1970] I.C.J. 4, 42.

35. Id. For comments on this decision, see Briggs, Barcelona Traction: The Jus Standi of Belgium, 65 AM. J. INT'L L. 327 (1971); Higgins, Aspects of the Case Concerning the Barcelona Traction, Light and Power Company, Ltd., 11 VA. J. INT'L $\mathrm{L}$. 327 (1971); Lillich, The Rigidity of Barcelona, 65 AM. J. INT'L L. 522 (1971); Metzger, Nationality of Corporate Investment under Investment Guaranty Schemes-The Relevance of Barcelona Traction, 65 AM. J. INT'L L. 532 (1971); Note, Protection of Shareholder Interests in Foreign Corporations-Barcelona Traction Reoisited, 41 FoRDHAM $L$. REv. 394 (1972); 5 J. INT'L L. \& EcoN. Develolment 239 (1971); Note, Economic Internationalism us. National Parochialism: Barcelona Traction, $3 \mathrm{~L}$. \& PolicY in INT'L Bus. 542 (1971); 3 N.Y.U.J. INT'L L. \& POL. 391 (1970).

36. [1961] I.C.J. 9. 
gium's application was thus dismissed and the merits of the case were not considered by the court.

The central issue was the competence of Belgium to extend protection to Belgian shareholders in a company which is a juridical entity incorporated in Canada. The actual and ultimate deprivations as caused by the illegal treatment of the "company" were, of course, sustained by the shareholders. The court, however, building upon the traditional myth of state responsibility (state rights independent of the injured individual), phrased the issue this way:

Has a right of Belgium been violated on account of its nationals' [sic] having suffered infringement of their rights as shareholders in a company not of Belgian nationality? ${ }^{37}$

While the court conceded that individual shareholders do ultimately suffer for damage done to the company, it emphasized that the company, as a corporate entity, retains its own separate legal personality, independent of its shareholders. Though the company is "in a precarious financial situation," that condition does not constitute "the demise of the corporate entity." 38 Unless and until there is "the legal demise of the company," according to the court, there is no "independent right of action" for the shareholders and thus for their governments to espouse their claims. ${ }^{39}$

The court further observed that the company, endowed with the "nationality" of Canada because of its incorporation in Canada, would look only to Canada for protection. Although Canada ceased to espouse the company's claim after 1955, "[ $[\mathrm{t}]$ he Canadian Government has nonetheless retained its capacity to exercise diplomatic protection" for Barcelona Traction. ${ }^{40}$ The Canadian government had absolute discretion to decide whether or not to exercise its right of protection:

The state must be viewed as the sole judge to decide whether its protection will be granted, to what extent it is granted, and when it will cease. It retains in this respect a discretionary power the exercise of which may be determined by considerations of a political or other nature, unrelated to the particular case. Since the claim of the state is not identical with that of the individual or corporate person whose cause is espoused, the state enjoys complete freedom of action. ${ }^{41}$

37. [1970] I.C.J. 4, 34.

38. Id. at 41 .

39. Id.

40. Id. at 44

41. Id. at 45 . 
The court finally cautioned that a Pandora's box would be opened if shareholders' governments were allowed to espouse their claims:

The Court considers that the adoption of the theory of diplomatic protection of shareholders as such, by opening the door to competing diplomatic claims, could create an atmosphere of confusion and insecurity in international economic relations. The danger would be all the greater inasmuch as the shares of companies whose activity is international are widely scattered and frequently change hands. ... As the right of protection vested in the national State of the company cannot be regarded as extinguished because it is not exercised, it is not possible to accept the proposition that in case of its non-exercise the national States of the shareholders have a right of protection secondary to that of the national State of the company. 42

In contemporary law it is thus apparent that the individual human being is almost completely dependent upon a state of nationality for securing a hearing upon the merits upon injuries done to him by other states.

\section{B. Claims Relating to the Conferment of Nationality}

International law accords states a high degree of discretion in the conferment of nationality. It is far from clear what limitations are imposed on the competence of states. The Hague Convention on Nationality of $1930^{ \pm 3}$ provides, somewhat ambivalently, both a grant of competence and a limitation. The grant of competence in articles 1 and 2 stipulates that "[i]t is for each State to determine under its own law who are its nationals" and that "[a]ny question as to whether a person possesses the nationality of a particular State shall be determined in accordance with the laws of that State." The stated limitation is that the nationality law of each state "shall be recognised by other States in so far as it is consistent with international conventions, international custom, and the principles of law generally recognised with regard to nationality." 14 Unfortunately, the Convention nowhere specifies the conferment criteria that are recognized or required by international law.

Any criteria that limit states' competence to confer nationality must

42. Id. at 49 .

43. The Convention on Certain Questions Relating to the Conflict of Nationality Laws, signed at the Hague, April 12, 1930, 179 L.N.T.S. 89 . See 5 M. Hudson, INTERNATIONAL LEGISLATION 359 (1936).

44. The Convention on Certain Questions Relating to the Conflict of Nationality Laws, supra note 43 , art. 1 . 
be inferred from customary practice. Thus, states have commonly utilized either or both of two major principles: jus sanguinis and jus soli. ${ }^{4 \bar{s}}$ The older of the two principles, jus sanguinis-conferment of nationality by blood relation (descent)-is at least as old as Roman law and is preferred by the civil law countries. The principle of jus soli-conferment of nationality based on place of birth-is an outgrowth of the feudal system favored by the common law countries. The overwhelming trend is toward a mixed system that employs both principles in varying combinations. ${ }^{46}$. The uniformity in exclusive reliance upon these two principles has been such as to suggest to some commentators the emergence of a customary rule that no other grounds are permissible. ${ }^{47}$

The important point from the perspective of human rights is that these two principles for conferment of nationality at birth disregard human volition. The individual selects neither his parents nor his place of birth. The great bulk of mankind have their nationality thrust upon them, with little effective prospect of change.4s

With reference to grounds subsequent to birth, states have sought to confer nationality upon a finding of express consent or a variety of factors, in which consent may or may not be included. ${ }^{49}$ Among these latter factors are marriage, recognition by affiliation, legitimation, adoption, residence (domicile), immigration animo manendi, ${ }^{50}$ land ownership, paternity, appointment as a university professor, ${ }^{51}$ and holding a public post.

45. See Sandifer. A Comparative Study of Laws Relating to Nationality at Birth and to Loss of Nationality, 29 AM. J. INT'L L. 248, 249.6I (1935); cf. Winter, Nationality or Domicile? The Present State of Affairs, 128 Hague Recueil 347 (1969).

"Countries of emigration," observed the Harvard Research, "are inclined to emphasize the jus sanguinis for the purpose of retaining the allegiance of descendants of their nationals who have settled in various parts of the world, while countries of immigration, including some countries of Asia and Africa, as well as those in the western hemisphere, are inclined to emphasize the $j u s$ soli, in order to have the allegiance of persons born within their territories of alien parents." Harvard Research, supra note I, at 39 .

46. "From an examination of the nationality laws of the various states," according to the often-quoted Harvard Research, "it appears that seventeen are based solely on jus sanguinis, two equally upon jus soli and jus sanguinis, twenty-five principally upon jus sanguinis but partly upon jus soli and twenty-six principally upon $j u s$ soli and partly upon jus sanguinis. The nationality law of no country is based solely upon jus soli. A combination of the two systems is found in the laws of most countries." Harvard Research, supra note 1 , at 29.

47. See, e.g., Article 3 of the Harvard Draft Convention on the Law of Nationality: "A state may not confer its nationality at birth upon a person except upon the basis of (a) the birth of such person within its territory or a place assimilated thereto (jus soli), or (b) the descent of such person from one of its nationals (jus sanguinis)." Id. at 13, 27; Hudson, supra note 1, at 7 .

48. See pp. 925-28 infra.

49. See Harvard Research, supra note 1, at 83-98; Hudson, supra note 1, at 8.

50. See Brownlie, supra note 1 , at 308 .

51. See Hudson, supra note 1 , at 8 . 
Conferment upon the basis of consent is, of course, in conformity with our recommended policy of human dignity. The "general principle" underlying naturalization in its most comprehensive sense is "the voluntary choice by an individual of a particular nationality." 52

To impose naturalization upon individual persons against their will, individually or collectively, on the other hand, is incompatible with the commonly accepted principles of international law. Thus, compulsory conferment upon such bases as land ownership or residence is impermissible. ${ }^{53}$ For instance, in the nineteenth century, when certain Latin-American states (e.g., Peru and Mexico) imposed nationality upon aliens who had acquired real property in the country, that practice was protested by other states and was held incompatible with international law by international tribunals. In the Anderson and Thompson case, ${ }^{54}$ Mexico had objected to the jurisdiction of the United States-Mexico Mixed Claims Commission in connection with a claim of the United States on behalf of two of its nationals. Mexico argued that both Anderson and Thompson had become, under the Mexican Constitution of 1857, Mexican nationals by purchasing land in Mexico in 1863. Dismissing the Mexican demurrer, Umpire Lieber declared that, although the Mexican Constitution "clearly means to confer a benefit upon the foreign purchaser of land, ... equity would assuredly forbid us to force this benefit upon claimants . . . merely on account of omitting a declaration of a negative." 55 Because the Mexican Nationality Law of 1886 contained the same feature, a similar issue arose subsequently in the Rau case before the GermanMexican Claims Commission in $1930 .{ }^{56}$ Again, Mexico objected to the Commission's jurisdiction over the German claim on behalf of its alleged national who had acquired land in Mexico. Dismissing the Mexican objection, the Commission emphatically stated that "international law ... does not permit compulsory change of nationality." ${ }^{7}$ Mexico subsequently withdrew its counterclaim and the objectionable provisions were abandoned in later Mexican Nationality Laws. ${ }^{58}$

Imposition of nationality on the mere ground of residence is similarly impermissible. For instance, in 1889, the Provisional Govern-

52. J. Jones, British Nationality Law and Practice 15 (1947).

53. See P. WeIs, supra note 1, at 104-16; Hudson, supra note 1 , at 8 .

54. $3 \mathrm{~J}$. MOORE, INTERNATIONAL ARBITRATIONS 2479 (1898).

55. Id. at 2479-81.

56. In re Rau, [1931-32] Ann. Dig. 251 (No. 124) (German-Mexican Claims Commission 1930).

57. Id.

58. See, e.g., art. 30, The Mexican Constitution of 1917, as amended by Decree of 18 January 1934, LAws CoNCERNING NATIONALITY, supra note 1, at 307. 
ment of Brazil issued a decree that all aliens residing in Brazil on November 15, 1889, would automatically be regarded as Brazilian nationals unless they should declare, within six months, a contrary intention before appropriate Brazilian officials. ${ }^{59}$ This proclamation provoked severe condemnation and protests of nonrecognition by other states, notably Italy, Great Britain, France, Spain, Portugal, Austria-Hungary, and the United States. ${ }^{60}$

A more recent example relates to Argentina. A bill purporting to confer automatic Argentine nationality on aliens after two years' residence led to such an outburst of protests by other governments that it was finally withdrawn..$^{01}$

Perhaps the most notorious example is the mass imposition of German nationality on nationals of territories occupied by Germany during World War II. In 1943 Hitler also purported to confer German nationality on all foreign nationals of "German origin" then serving in the German armed forces. In 1951, this matter was raised in the Compulsory Grant of German Nationality Case ${ }^{62}$ before a court of the German Federal Republic. The applicant, in German custody, was sought by Austria for extradition; he was a person of "German origin" serving in the German army at the time of Hitler's decree. He thus claimed nonextradition on the basis of his being a German national. The Court of Appeal of Neustadt declared Hitler's decree invalid on the ground that only the Reichstag, not the Chancellor, was empowered to prescribe naturalization matters at that point in time. The applicant was not a German national and was thus extradited to Austria. Subsequently, in 1955, the German Federal Republic undertook to enable all persons purporting to have been made German nationals under the compulsory Nazi measures to "disclaim German nationality by an explicit declaration to that effect." $" 3$

59. See P. WeIs, supra note 1 , at 105-06.

60. See $i d$. at $106-08$.

61. See Hudson, supra note 1, at 8. Note, however, article 31 of the Constitution of the Argentine Republic:

Foreigners who enter the country without violating the laws shall enjoy all the civil rights of Argentinians, as well as political rights, five years after having obtained Argentinian nationality. Upon their petition they may be naturalized if they have resided two consecutive years in the territory of the Nation, and they shall acquire Argentinian nationality automatically at the end of five years of continuous residence in the absence of express declaration to the contrary.

1 A. Peaslee, Constitutions of Nations 51 (2d ed. 1956).

Dean John $H$. Wigmore proposed that nationality be based on domicile and that two years' residence in a state automatically results in acquisition of the nationality of that state. See Wigmore, Domicile, Double Allegiance, and World Citizenship, 21 ILL. L. REV. 761 (1927).

62. Compulsory Grant of German Nationality Case, [1951] I.L.R. 247 (Court of Appeal of Neustadt, German Federal Republic 1951).

63. Art. 1, Settlement of Nationality Questions Act of 1955, Supplement to Laws CoNCERNing NATIONALITY, supra note 1 , at 116. 
In the case of conferment upon such grounds as marriage, legitimation, adoption, and recognition by affiliation, inquiry may be made to ascertain the degree of volition actually present. Since, however, the activities described by these grounds are widely known to carry the consequence of nationality and often entail basic community policies about collateral problems which make nationality a desirable consequence, it is a common practice of decisionmakers to infer or assume a voluntary act on the part of the individual or those representing him. Thus, an act which has "a direct relation to nationality" may be considered to show "unquestionably the desire and intention of a person to take the nationality of a state." 04

The classic summary is that of Hall:

Consent no doubt may be a matter of inference: and if the individual does acts of a political, or even, possibly, of a municipal nature, without inquiry whether the law regards the performance of such acts as an expression of desire on his part to identify himself with the state, he has no ground for complaint if his consent is inferred, and if he finds himself burdened upon the state territory with obligations correlative to the privileges which he has assumed. But apart from acts which can reasonably be supposed to indicate intention, his national character may with propriety be considered to remain unaltered. It is unquestionably not within the competence of a state to impose its nationality in virtue of mere residence, of marriage with a native, of the acquisition of landed property, and other such acts, which lie wholly within the range of the personal life, or which may be necessities of commercial or industrial business. ${ }^{65}$

However, the element of voluntarism or consent may, as in the case of married women and minors, often be minimal or a mere fiction.

With regard to the effect of marriage on nationality, national laws differ widely. ${ }^{66}$ Basically speaking, there are two opposing principles governing the law on the nationality of married women. The traditional principle is the unity of the family, according to which the nationality of all members of the family-mother, father, and children under age-should be the same, in order to avoid split loyalty within the family. The second principle honors the freedom of a married woman to choose her own nationality. Under the interplay of these

64. Harvard Research, supra note 1 , at 54 .

65. W. Hall, InTERnational LAW 267-68 (8th ed. 1924).

66. See United Nattons, Nationality of Married Women (1963); United Nations, Convention on the Nationality of Married Women (1962); W. Waltz, The NaTIONALITY OF MARRIED WOMEN (1937). 
two basic principles, municipal laws about the nationality of married women can be divided into three categories: (1) the nationality of the wife follows automatically that of the husband; (2) though marriage to a man of a different nationality affects the nationality of the wife, provisions are made to avoid the wife's statelessness or double nationality; and (3) the woman has the right to choose her own nationality and marriage will not affect the nationality of the wife. According to a recent United Nations study, an alien woman automatically acquires the nationality of her husband upon marriage under the law of 28 states; under the law of 68 states, the alien wife may on certain conditions acquire the nationality of the husband; and under the law of 12 states marriage of an alien woman to a national has no effect whatever on her nationality. ${ }^{67}$

The United States Supreme Court once suggested that the marriage of a woman to an alien caused her to lose her nationality because it amounted to "voluntary expatriation"; the woman freely contracted the marriage with notice of the consequences. ${ }^{68}$ Because marriage is generally stipulated to affect only the wife's-not husband's-nationality, such rationalization is difficult to reconcile with the principle of the equality of the sexes.

Indeed, from the perspective of individual human rights, marriage should have no automatic effect on the nationality of either the wife or the husband. An alien woman, in marrying a national, does not necessarily signify her intention to identify with the state of which her husband is a national or to sever her ties with the state of her nationality. With the growing emphasis on the equality of the sexes, particularly in the wake of the current movement for the liberation of women, the trend is away from the principle that a married woman's nationality is automatically that of her husband. ${ }^{69}$ Article 1 of the Convention on the Nationality of Married Women emphatically affirms this trend:

Each Contracting State agrees that neither the celebration nor the dissolution of marriage between one of its nationals and an alien, nor the change of nationality by the husband during marriage, shall automatically affect the nationality of the wife. ${ }^{70}$

67. Nationality of MARried Women, supra note 66, at 122-25 (Annex).

68. Mackenzie v. Hare, 239 U.S. 299 (1915).

69. See Nationality of MAkRIED WoMEN, supra note 66 , at 7 .

70. The Convention was opened for signature and ratification by General Assembly Resolution 1040 (XI) of 29 January 1957; it became effective on August 11, 1958. UNITED Nations, Human Rights: A CoMpilation of INTERNATIONAL INSTRUMENTS OF the UNITED NATIONS 52 (1967) [hereinafter cited as U.N. HUMAN RIGHTS INSTRUMENTS]. For the history and commentary of this Convention, see Convention ON The Nationality of Markied WoMEN, supra note 66. For its text see 309 U.N.T.S. 65. 
With respect to minor children, the maintenance of family unity would seem to compel the rule that the child follows the father's nationality in the case of legitimation and adoption and that minor children are naturalized through the naturalization of their parents. ${ }^{71}$ However, because the element of volition is absent on the part of minors, it has increasingly been urged that minors be given the option to resume their original nationality when they attain adulthood. ${ }^{72}$

Compulsory naturalization has often been associated with territorial change. ${ }^{73}$ For instance, when one state cedes a territory to another, the ceding state is considered competent to transfer the allegiance of the inhabitants and the transfer is deemed an automatic consequence of the cession. The acquiring state has been traditionally required, at the same time, to confer its nationality, though not the political rights of citizens, upon those persons. ${ }^{74}$ Upon occasion, however, these harsh doctrines are modified in deference to human rights and self-determination. Sometimes a plebiscite is employed to determine whether a transfer of territory is in accord with the wishes of the majority of the inhabitants concerned. ${ }^{75}$ More frequently, state practice-as embodied in many treaties of cession or of peace-seeks to allow individual inhabitants of the ceded territory an option on nationality, including the retention of the original nationality. ${ }^{78}$ Thus, the Inter-

71. See $\mathrm{P}$. WEIs, supra note $\mathrm{I}$, at 114 .

72. See, e.g., the nationality laws of Australia, Belgium, Bulgaria, Canada, Ceylon, Ecuador, Great Britain, Ghana, Greece, India, Luxembourg, Malaya, Monaco, Netherlands, New Zealand, Pakistan, Syria, Sudan, Thailand, Venezuela, and Union of South Africa, in Laws Concerning Nationality, supra note 1.

73. See P. WEIS, supra note 1, at 139-64; Hudson, supra note 1, at 8-10; Mann, The Effects of Changes of Sovereignty upon Nationality, 5 MODERN L. REv. 218 (1942).

74. See P. Jessur, A Modern Law of Nations 76 (1952); cf. H. Briggs, supra note 10 , at $501-05$.

75. On plebiscites, see generally H. JOHNSON, SELF-DererMINATION WITHIN THE COMmunity of Nations (1967); J. Mattern, The Employment of the Plebiscite in the Determination of Sovereignty (1920); 1 \& 2 S. Wambaugh, Plebiscites Since the World War (1933); S. Wambaugh, A Monograph of Plebiscites (1920); Chen \& Reisman, Who Owns Taiwan: A Search for International Title, 81 YALE L.T. 599, 660-69 (1972).

76. See 1 L. Oppenheim, International Law 551 (8th ed. H. Lauterpacht 1955) [hereinafter cited as Oppenhein-Lauterpacht]; Gettys, The Effect of Changes of Sovereignty on Nationality, 21 AM. J. INT'L L. 268, 271 (1927); Hudson, supra note 1, at 9.10; Kunz, Nationality and the Option Clauses in the Italian Peace Treaty, 41 AM. J. INr'L L. 622 (1947).

Lord McNair observed:

The hardship of an involuntary change of nationality has led with increasing frequency in recent years to the adoption of one of the following forms of mitigation: (a) Plebiscite. The treaty may stipulate for the cession of particular pieces of territory to depend upon the result of a plebiscite by the nationals of the ceding State inhabiting the territory; such a provision occurs in several articles of the Peace Treaties of 1919-1920, but it was not generalized;

(b) Option of nationality. The treaty may give the nationals of the ceding State inhabiting the territory ceded an option to retain the nationality of the ceding State; if they exercise that option, the acquiring State may, in default of contrary stipulation, expel them as any aliens may be expelled; 
American Convention on Nationality concluded at Montevideo in 1933 contains the following provision in article 4:

In case of the transfer of a portion of the territory on the part of one of the States signatory hereof to another of such States, the inhabitants of such transferred territory must not consider themselves as nationals of the State to which they are transferred, unless they expressly opt to change their original nationality. ${ }^{77}$

One harsh qualification is that "failing a stipulation expressly forbidding it, the acquiring State may expel those inhabitants who have made use of the option and retained their old citizenship, since otherwise the whole population of the ceded territory might actually consist of aliens and endanger the safety of the acquiring State." 78 It would appear vital from a human rights perspective, nevertheless, that those individual inhabitants who have chosen not to acquire the new nationality be free to reside on the ceded territory.

One important concession in favor of human rights is that states are not regarded as competent to impose nationality upon individuals who are not physically present within a territory at the time of its transfer. ${ }^{70}$ It is said that the nationality of the successor state can be conferred upon nationals of the predecessor state only if they submit voluntarily to its jurisdiction, by virtue of an explicit declaration or voluntary return to their land of origin. This position was spotlighted in United States ex rel. Schwarzkopf v. Uhl, District Director of Immigration, ${ }^{80}$ where the court held that an Austrian national who had been resident in the United States when Germany annexed Austria had not acquired German nationality.

With respect to the converse dimension of the naturalization problem, we must note that some of the most significant deprivations of human rights are a consequence of the denial of naturalization to people who actively seek it. Doctrine holds that naturalization is a privilege within the discretion of the state, not a right of the applicant. As the United States Supreme Court put it,

(c) Option to emigrate. The treaty may give the inhabitants an option to emigrate within a certain time and also retain their nationality.

The growth of the principle of self-determination tends to favour the adoption of one or more of these palliatives. It must, however, be emphasized that the law does not enjoin them and they do not apply unless the high contracting parties choose to adopt them.

A. MCNair, Legal EfFects of WAR 388-90 (3d ed. 1948).

77. 6 M. Hudson, International Legislation 593 (1937); Laws Concerning NaTIONALITY, supra note 1 , at 585 .

78. 1 Oppenheim-Lauterpacht, supra note 76, at 552 .

79. See Hudson, supra note 1 , at 9 .

80. 137 F.2d 898 (2d Cir. 1943). 
Naturalization is a privilege, to be given, qualified, or withheld as Congress may determine, and which the alien may claim as of right only upon compliance with the terms which Congress imposes. ${ }^{81}$

States differ widely in the scope and severity of limitations imposed on voluntary naturalization. These limitations may include residence, age, moral character, race, political character, health, skill, and wealth of the applicant. ${ }^{82}$ These preconditions for naturalization, including as well administrative hurdles, are so onerous, unfortunately, that people who seek naturalization are often denied it.

For example, residence, regarded as the most significant indicator of a person's factual attachment to a territorial community, is a common precondition for naturalization. The overriding importance of the residence requirement as an inhibition upon naturalization derives from the fact that access to territory, with appropriate immigrant status, is a precondition to fulfilling the residence requirement; such access is itself subject to many difficult and arbitrary conditions. ${ }^{\text {s3 }}$ States differ, moreover, in the requirements they impose with respect to length of residence and the necessity of physical presence. The length of residence requirements range from two to ten years. While there has been a trend toward greater uniformity (typically three or five years), some states still demand a longer period of residence. ${ }^{84}$

Some states require that an applicant for naturalization be of good character at the time his petition is filed..$^{85}$ The United States, however, insists further that the applicant demonstrate "good moral character" throughout the required "probationary period" of residence. ${ }^{80}$ The requirement of good moral character, elusive and susceptible of arbitrary application, has proved to be the principal source of litigation concerning naturalization in the United States. ${ }^{87}$ Though good

81. United States v. Macintosh, 283 U.S. 605, 615 (1931). See also Fong Yue Ting v. United States, 149 U.S. $698,707.08$ (1893).

82. Cf. Harvard Research, supra note 1 , at 83-100.

83. We will explore this problem in connection with the claims to freedom of movement, including claims of access to territory.

84. Harvard Research, supra note 1, at 89-91.

85. See, e.g., Norway, art. 6(3), Nationality Act No. 3 of 8 December 1950, LAws CONCERning Nationality, supra note 1, at 352, 353; Japan, art. 4(3), Nationality Law of 4 May 1950, id. at 271, 272; British Nationality Act of 30 July 1948, Second Schedule, Sec. 1 (c), id. at 468,482 .

86. 8 U.S.C. $\$ 1427(a)(3)(1970)$ provides:

No person, except as otherwise provided in this subchapter, shall be naturalized unless such petitioner ....(3) during all the period referred to in this subsection [usually five years] has been and still is a person of good moral character, attached to the principles of the Constitution of the United States, and well disposed to the good order and happiness of the United States.

87. See Developments in the Law-Immigration and Nationality, 66 HaRv. L. Rev. $643,710(1953)$. 
moral character was made a requirement for naturalization as early as $1790,{ }^{88}$ the term was undefined by statute until 1952 . In 1952, Congress sought to mitigate the confusing and controversial state of the law by enumerating specific grounds, such as drunkenness, adultery, polygamy, prostitution, and gambling, that would preclude a finding of good moral character. ${ }^{89}$ Nevertheless, the good moral character test has remained a source of uncertainty for persons seeking naturalization and the Immigration and Naturalization Service and the courts continue to enjoy wide discretion in applying it. Even if an applicant for naturalization has committed none of the proscribed acts, a court is not barred from "finding that for other reasons such person is or was not of good moral character." 90 The arbitrary and inconsistent application of this requirement is amply illustrated by the controversies concerning the sexual behavior of unmarried aliens and the suitability of homosexuals for citizenship. ${ }^{91} \mathrm{~A}$ commentator has thus critically observed that

intelligibility is one of the finest attributes of law, if not its essence; and that on these grounds alone a statutory requirement [good moral character] destined to be empty of legal meaning for its entire legal existence should not properly be part of law. ${ }^{92}$

The net effect, as before 1952, is significant deprivations of human rights. The requirement of good moral character has become the foremost obstacle to naturalization.

Equally susceptible of abuse are requirements relating to political activities. It has been a common practice of states to require aliens seeking naturalization to take an oath of allegiance. Some states have gone further to stipulate that the commission of certain political acts by an applicant would operate to bar his naturalization. While some states couch this requirement generally in terms of conduct detrimental to the interests of the state, ${ }^{93}$ some have undertaken specific formulations. The United States, in particular, is most explicit in this regard. Thus, in addition to requiring adherence to the principles of

88. See Note, Good Moral Character in Naturalization Proceedings, 48 CoLum. L. REv. 622 (1948).

89. 8 U.S.C. $\$ 1101(f)(1970)$.

90. Id.

91. See Newton, On Coherence in the Law: A Study of the "Good Moral Character" Requirement in the Naturalization Statute, 46 TEMP. L.Q. 40, 43-59 (1972); Note, Naturalization and the Adjudication of Good Moral Character: An Exercise in Judicial Uncertainty, 47 N.Y.U. L. REv. 545, 560-82 (1972).

92. Newton, supra note 91 , at 70 .

93. See, e.g., Albania, art. 7(5), Nationality Act No. 377 of 1946, Laws ConCERNING NAtionality, supra note 1 , at 4, 5; France, art. 70, Nationality Code of 1945, id. at 152, 161; Hungary, art. 4(b), Nationality Act LX of 1948, id. at 219, 220 . 
the Constitution and a favorable disposition to the United States, ${ }^{94}$ the Immigration and Nationality Act of 1952 specifically prohibits the naturalization of persons opposed to government or law, persons who favor totalitarian forms of government, ${ }^{95}$ and persons who have deserted from the United States Armed Forces. ${ }^{98}$

In sum, it is apparent that conferment of nationality at birth is not a volitional act of the individual concerned. Though states give consent greater emphasis in connection with conferment of nationality after birth, involuntary naturalization is far from a rare occurrence and efforts toward voluntary acquisition of nationality often fail. Given the differential distribution of resources and opportunities for value shaping and sharing about the globe, the instability and fragility of the inherited organizations of territorial communities, and the ever increasing mobility of people and frequency of transnational interactions, every individual person should be free to effect a voluntary change in his nationality and thus to identify with the political community of his own choice. The fact that a person possesses a particular nationality at birth, or after birth, should not condemn him in perpetuity to membership in a body politic which may be perceived by him to be more oppressive than protective. As a matter of human rights every person should be free to change his nationality. Thus, the Universal Declaration of Human Rights proclaims that "[n]o one shall be arbitrarily . . . denied the right to change his nationality." 07 Similarly, the American Convention on Human Rights provides that "[n]o one shall be arbitrarily deprived ... of the right to change [nationality]." ${ }^{8}$ Unfortunately, however, the International Covenant on Civil and Political Rights and the European Convention on Human Rights lack comparable provisions.

\section{Claims Relating to Withdrawal of Nationality}

The nationality of an individual may be withdrawn or lost upon the initiative of the individual or of the state conferring nationality and with or without the individual's consent. When an individual takes the initiative to terminate a nationality, he is said to engage in voluntary expatriation. ${ }^{99}$ When a state conditions its withdrawal of

\footnotetext{
94. 8 U.S.C. $\$ 1427$ (1970).

95. Id. $\$ 1424$.

96. Id. \$ 1425 .

97. U.N. Human Rights INSTRUMents, supra note 70, at 2 (art. 15(2)).

98. Basic Documents on International Protection of Human Rights (L. Sohn \& T. Buergenthal eds. 1973) (art. 20(3)) [hereinafter cited as BAsIC Documents].

99. As Maxey has pointed out, "the word "expatriation' tends to be used indis. criminately, in both judicial discussion and popular speech, as comprehending all losses
} 
nationality upon the genuine consent of the individual, no problem concerning human rights arises. The difficulty is that the line between genuine consent and involuntary withdrawal is often difficult to perceive. For purposes of economy, we follow the traditional categorizations of (1) voluntary expatriation, (2) withdrawal upon consent (genuine or constructive), and (3) involuntary withdrawal, noting the difficulties as we progress.

\section{Voluntary Expatriation}

It has already been observed that the right to change a nationality is increasingly regarded as a fundamental human right. ${ }^{100}$ It is only by guaranteeing this right that the world community affords individuals opportunity to escape the bondage of the effective elites of any particular community. The right to renounce nationality-"voluntary expatriation"-is of course an indispensable component of the right to change it. Similarly, just as open access to territory is a precondition to any realistic right to acquire nationality, so here a right of egress is a necessary condition to any effective right of voluntary expatriation. ${ }^{101}$ Unless an individual can escape the bounds of a country, he may find it impossible to free himself from the shackles of its nationality. There would appear to be a slow trend toward protecting a right of voluntary expatriation.

The demand for a right of voluntary expatriation has, despite the long insistence by states upon indissoluble allegiance, a very ancient history. Its roots are deep in Greek and Roman thought. Thus, a United States Senator, citing Plato as authority, stated that

[a]t Athens it was permitted to each person upon examining the laws and customs of the republic, if there was nothing found to his charge, to retire with all of his goods, wherever else it pleased him. ${ }^{102}$

of national status, however brought about. Failure to observe sharply demarcated terminological boundaries has frequently been a source of confusion in this area of inquiry; this is especially true in the United States, where the concept of voluntary expatriation, through constant distortion, bears little, or no resemblance to the original notion, as expressed in the statutory declaration of 1868." Maxey, Loss of Nationality: Individual Choice or Government Fiat?, 26 Albany L. Rev. 151, 151-52 (1962). See also 5 J. Verzijl, International Law in Historical Perspective 4244 (1972). For our purposes, expatriation refers strictly to "voluntary expatriation" (in which a person takes initiative to terminate a nationality) and is to be distinguished from loss of nationality resulting from imputed consent and from involuntary withdrawal of nationality. 100. See p. 928 supra.

101. See H. Lauterpacht, An International Bill of the Rights of MaN 129-33 (1945); H. LAUterpacht, International Law and Human Rights 346-50 (1950).

102. Cong. Globe, 40th Cong., 2d Sess. 4232 (1868) (remarks of Senator Patterson). 
Similarly, Hersch Lauterpacht, in making a strong case for the right of expatriation, builds upon the thought of Socrates and Cicero. ${ }^{103}$ In the words of Socrates,

if any one does not like the city and its constitution, there is no law to hinder or prevent him from going away whenever he likes, either to the colonies or to some foreign country and taking his property with him. ${ }^{104}$

Notwithstanding his deference to state sovereignty, Vattel was eloquent in defense of the right of expatriation. He stated that

every man is born free, and therefore the son of a citizen, when arrived at the age of reason, may consider whether it is well for him to join the society in which he happens to be by birth. If he does not find that it is to his advantage to remain in it, he has the right to leave it. ... A citizen may therefore leave the State of which he is a member, provided it be not at a critical moment when his withdrawal might be greatly prejudicial to the State. ${ }^{105}$

The right of the individual to expatriation was incorporated in the French Constitution of September 3, 1791. ${ }^{106}$ It is, however, the United States that has been the foremost champion of the right of voluntary expatriation. In 1868, with a view to freeing recently naturalized Americans from the allegiance demanded by the states from which they had emigrated, the United States Congress proclaimed that

the right of expatriation is a natural and inherent right of all people, indispensable to the enjoyment of the rights of life, liberty, and the pursuit of happiness;...

[a]ny declaration, instruction, opinion, order, or decision of any officers of this government which denies, restricts, impairs, or questions the right of expatriation, is hereby declared inconsistent with the fundamental principles of this government. ${ }^{107}$

The purpose of the Act of 1868, in the words of Hyde, was

to make clear the doctrine, first, that the freedom of an alien to change his nationality through naturalization, in so far as he had any part in the matter, was not dependent upon the consent of his

103. H. Lauterpacht, AN International Bill of the Rights of MAN 130-31 (1945).

104. Quoted in id. at 131.

105. 3 E. DE VATTEL, supra note 7 , at 89.

106. See C. De Visscher, Theory and Reality in Public International Law 185 (P. Corbett transl. rev. ed. 1968).

107. Act of July 27, 1868, ch. 249, 15 Stat. 223 (1868). The Fourteenth Amendment was passed in the same year. 
sovereign beyond whose control he had placed himself; secondly, that naturalization within the United States served to dissolve the tie of allegiance with respect to that sovereign; and thirdly, that by such process the individual acquired a new national character entitled to recognition upon his return to the country of origin. ${ }^{10 s}$

Similarly, departing from the doctrine of "indissoluble allegiance," Great Britain acknowledged a limited right of voluntary expatriation in its Naturalisation Act of 1870, declaring:

Any British subject who has at any time ... when in a foreign state and not under any disability voluntarily become naturalized in such state, shall ... be deemed to have ceased to be a British subject. 109

At the 1930 Hague Conference for the Codification of International Law, the United States Delegation made a strong plea for the incorporation of the principle of voluntary expatriation in these words:

For a century past, it has been the policy of my country that the right of expatriation is an inherent and natural right of all persons. It is true that allegiance is a duty, but it is not a chain that holds a person in bondage and that he carries with him to a new life in a new land. It is a duty and an obligation that a free man casts off when he voluntarily assumes allegiance to the country of his new home, and takes over the duties and the rights of a national there. When he accepts the new tie, the old one is loosed and gone. This principle is not a small matter. It is not a question of language, or of formulae, or of phrases. It is a principle of the rights of man and of the liberty of the human race. ${ }^{110}$

Though exhibiting some ambivalence, the delegates to the Conference did not fully accept this policy. Thus, the Final Act of the Conference noted that it was desirable

that States should apply the principle that the acquisition of a foreign nationality through naturalization involves the loss of the previous nationality,

108. 2 C. Hyde. International Law: Chiefly as Interpreted and Applied by the UNITED STATES 1147.48 (2d rev. ed. 1945) (footnote omitted). The policy embodied in the 1868 Act found further expression in a series of treaties, known as Bancroft Treaties, the United States had concluded respectively with Badden (1868), Bavaria (1868), Hesse (1868), Belgium (1868), Sweden and Norway (1869), Austro-Hungary (1870), Great Britain (1872), Ecuador (1872), and Denmark (1872).

109. Sec. 6, British Naturalisation Act of 1870 , reprinted in J. JoNEs, British NAtionality Law and Practice 88 (1947). See C. Parry, Nationality and Citizenship Laws of the Commonwealth and of the Republic of Ireland 78-80 (1957).

110. 2 League of Nations, Acts of the Conference for the Codification of INternational Law, Meetings of the Committees: Nationality 80 (1930). 
and that,

pending the complete realization of the above principle, States before conferring their nationality by naturalization should endeavor to ascertain that the person concerned has fulfilled, or is in a position to fulfil, the conditions required by the law of his country for the loss of its nationality. ${ }^{111}$

This same ambivalence is apparent in state practice. Many states still do not recognize that an individual has the right, without condition, voluntarily to withdraw his nationality and to sever his ties with the country which claims him. ${ }^{112}$ So many conditions are commonly imposed that "conditional," rather than "voluntary," expatriation would appear to be the appropriate descriptive label. In a world in which people are still important bases of power, states are understandably reluctant to yield their controls.

Even where voluntary expatriation is nominally recognized, difficult barriers are erected. Notable among such barriers are the following:

(1) Exacting and carefully prescribed procedures must be followed to renounce nationality. For instance, a United States national, in voluntarily renouncing his nationality "when in a foreign state," is required to make a statement before a United States diplomatic or consular officer in the form prescribed by the Secretary of State. ${ }^{113}$ On the other hand, when the renunciation is made in the United States during a state of war, the individual must make a formal written renunciation pursuant to the form stipulated by, and before such officer as may be designated by, the Attorney General, who must determine that such renunciation is not contrary to the interests of national defense..$^{114}$

(2) An individual may not expatriate himself while he is in the territory of the state of expatriation. It is a practice for many countries, such as Germany and Switzerland, not to honor the individual's voluntary expatriation if the renunciation is made within the expatriating state.115 That expatriation is expected to occur abroad is also suggested by the frequent discussion of the right of voluntary expatriation in terms of automatic loss of nationality upon foreign naturalization. ${ }^{110}$

111. Final Act of the Conference for the Codification of International Law, LEAGue of Nations Publication Series 1930.V.7 (C.228.M.115.1990.V.), at 14 [hereinafter cited as Final Act of the Hague Conference].

112. Cf. Harvard Research, supra note 1 , at 45-48, $100-06$.

113. 8 U.S.C. $\$ 1481$ (a)(6) (1970).

114. Id. $\$ 1481(\mathrm{a})(7)$.

115. Sec. 25, (West German) Nationality Act of 22 July 1913, LAws Concerning NaTIONALITY, supra note 1, at 178, 183; art. 42, Swiss Nationality Act of 29 September $1952, i d$. at $443,449$.

116. Cf. 2 C. HYDE, supra note 108, at 1143-70; P. WEIs, supra note 1, at 131-38. 
The fact that expatriation often must occur abroad also reinforces the point that the right of voluntary expatriation and the right of emigration are closely linked.

(3) An individual may not expatriate himself while the expatriating state is at war. For example, Great Britain and many other Commonwealth countries specifically prohibit expatriation in a "foreign" (nonCommonwealth) state in time of war so as to prevent their nationals from evading military service. ${ }^{117}$ Naturalization when in an enemy state may be regarded as an act of treason. ${ }^{118}$

(4) Expatriation is conditional on release by the expatriating state. Increasingly, the achievement of expatriation is made contingent upon the grant of official permission by the expatriating state. And most states will not grant such permission unless and until the individual has fulfilled certain obligations, especially military service and payment of taxes. The "conditional expatriation" under the Soviet Union and its fraternal states is especially harsh, for the conditions to be met in order to obtain the required official permission are not publicly disclosed. ${ }^{119}$ In Jordan, conditions of release are related to ethnic origin. Though Jordanians not of Arab origin may renounce voluntarily their Jordanian nationality without state permission, those of Arab origin are required to secure release from the Council of Ministers unless they possess the nationality of another Arab state..$^{120}$

(5) The effect of voluntary expatriation is made contingent upon acquisition of another nationality. This widespread practice is justified on the basis of protecting the individual from becoming stateless. Thus, article 7 of the Hague Convention on Nationality provides in part:

In so far as the law of a State provides for the issue of an expatriation permit, such a permit shall not entail the loss of the nationality of the State which issues it, unless the person to whom it is issued possesses another nationality or unless and until he acquires another nationality. An expatriation permit shall lapse if

117. See, e.g., Australia, Nationality and Citizenship Act No. 83 of 1948, art. 18(5), Laws Concerning Nationality, supra note 1 , at 13, 19; Canada, Citizenship Act of 1916, sec. 15(2), id. at 69, 75; Ceylon, Citizenship Act No. 18 of 1948, sec. 18, id. at 83, 86; New Zealand, British Nationality and New Zealand Citizenship Act No. 15 of 1948, art. 21(2), id. at 337, 345; United Kingdom, Nationality Act of 1948, sec. 32(1), id. at 468, 480; Ghana, Nationality and Citizenship Act of 1957, sec. 15(1), SuppleMENT to LAws Concerning NATIONALITY, supra note 1 , at 126, 129; India, Citizenship Act No. 57 of 1955, art. 8(1), id. at 133, 136; Malaya, Constitution of 1957, Art. 23(2), id. at 36,39 .

118. See Rex v. Lynch, [1903] 1 K.B. 414.

119. See, e.g., art. 12, Decree No. 202 of October 29, 1924 of the U.S.S.R., in R. Flournoy \& $\mathrm{M}$. Hudson, supra note $\mathrm{I}$, at 514.

120. Jordan, Nationality Law No. 6 of 4 February 1954, arts. 15-17, LAws ConCERNING NATIONALITY, supra note I, at 277, 279. 
the holder does not acquire a new nationality within the period fixed by the State which has issued the permit. ${ }^{121}$

Similarly, Article $7(1)(a)$ of the Convention on the Reduction of Statelessness provides:

If the law of a Contracting State permits renunciation of nationality, such renunciation shall not result in loss of nationality unless the person concerned possesses or acquires another nationality..$^{122}$

The professed objective underlying these provisions seems commendable. However, given the difficulties involved in securing naturalization, as noted above, the requirement of acquiring another nationality has sometimes become more deprivatory than protective of the individual. Hence the significance of Article $7(1)(b)$ of the Convention on the Reduction of Statelessness:

The provisions of sub-paragraph (a) of this paragraph shall not apply where their application would be inconsistent with the principles stated in Articles 13 and 14 of the Universal Declaration of Human Rights approved on 10 December 1948 by the General Assembly of the United Nations. ${ }^{123}$

Articles 13 and 14 of the Universal Declaration of Human Rights, which we will explore elsewhere, deal with the freedom of movement, transnational as well as internal, and the right of asylum. ${ }^{124}$

Despite the various conditions mentioned above, it appears that in increasing degree strong community expectations support the

121. 179 L.N.T.S. 89,101 .

122. The Convention on the Reduction of Statelessness was adopted on August 30, 1961 , by a Conference of Plenipotentiaries which convened in 1959 and reconvened in 1961 pursuant to General Assembly Resolution 896 (IX) of 4 December 1954. As of June 30,1973 , it had not yet entered into force. For its historical background and commentary, see Weis, The United Nations Convention on the Reduction of Statelessness, 1961, 11 INT'L \& Comp. L.Q. 1073 (1962). For its text, see U.N. HuMAN RIGHTS INSTRUMENTs, supra note 70 , at 55 .

123. U.N. HuMAN Rights INSTRUMENTs, supra note 70, at 55.

124. Article 13 reads:

1. Everyone has the right to freedom of movement and residence within the borders of each State.

2. Everyone has the right to leave any country, including his own, and to return to his country.

And Article 14 reads as follows:

1. Everyone has the right to seek and to enjoy in other countries asylum from persecution.

2. This right may not be invoked in the case of prosecutions genuinely arising from non-political crimes or from acts contrary to the purposes and principles of the United Nations.

Id. at 2. 
individual's right of voluntary expatriation. As may be recalled, both the Universal Declaration of Human Rights and the American Convention on Human Rights provide that no one shall be "arbitrarily" denied the right to change his nationality.125 Unhappily both the International Covenant on Civil and Political Rights and the European Convention on Human Rights fail to protect this right. In formulating prescriptions in the future, proponents of human rights might well keep in mind Hersch Lauterpacht's admonition that the prohibition of arbitrary denial of change alone is not enough: ${ }^{126}$ The right that is "inherent in the human person" 127 and gradually taking its place among " 'the general principles of law recognized by civilized nations" "is more simply and comprehensively that the "right of emigration and expatriation shall not be denied."128

\section{Withdrawal with Consent (Genuine or Constructive) for Promoting Harmonious Relations Between States}

When withdrawal of nationality is with the genuine consent of the individual, such withdrawal may approximate voluntary expatriation and involve no problems of human rights. In the interest of promoting harmonious relations among themselves and avoiding situations of potential conflict, states may, however, disregard the question of genuine consent and impose loss of nationality upon an individual because of the "voluntary" performance of a variety of acts. The basic policy question with respect to expatriation in such contexts is whether the common interest of states in the avoidance of conflict is sufficiently substantial to justify the severe deprivations imposed upon nonconsenting individuals.

In historic practice states have, in pursuit of various policies, imposed loss of nationality upon individuals because of a wide variety of acts, ranging from the most explicit renunciation of nationality to instances in which consent is entirely fictitious. A brief itemization of this range includes: execution of formal instruments of renunciation, deliberate acquisition of the nationality of another state, taking an oath of allegiance to another state, protracted residence abroad, military service in the forces of foreign governments, voting in foreign political elections, employment by foreign governments, marriage to an alien man, and the naturalization of parents by another government.

125. See p. 928 supra.

126. H. Lauterpacht, International Law and Human Rights 348-49, 423 (1950).

127. C. DE VISSCHER, supra note 106, at 185.

128. H. LAUTERPACHT, supra note 126 , at $34 \%$; H. LAUTERPACHT, supra note 103 , at 129. 
With respect to some of these acts, the withdrawal of nationality occurs under conditions which clearly approximate genuine consent and recognition of withdrawal in such circumstances may indeed be necessary for making effective the human rights policies intimately connected with honoring voluntary expatriation. This is certainly true with respect to the execution of formal instruments of renunciation, the deliberate acquisition of the nationality of another state, and the taking of an oath of allegiance to another state. Execution of a formal instrument of renunciation, as indicated above, is the most explicit form of accomplishing voluntary expatriation..$^{129}$ In the case of naturalization in another state, the emphasis is on deliberate choice: Imposed naturalization, as mentioned above, obviously lacks voluntariness. ${ }^{130}$ Taking an oath or other formal declaration of allegiance to a foreign state, it is said, means less than total allegiance to an individual's own state, and places him in a peculiar position where his services might be claimed by more than one state, thereby making it practically impossible for his state of nationality to provide him protection vis-à-vis that foreign state. ${ }^{131}$ The policy consideration favoring presumption of voluntariness in regard to taking an oath of allegiance to a foreign state is understandable; the difficulty lies in ascertaining what constitutes an oath of allegiance, for the types of oath may vary from "ironbound pledges of allegiance to vague and ambiguous affirmations of fealty or obedience." 132 Criteria for ascertainment have been suggested by Secretary of State Hughes in these words:

It is the spirit and meaning of the oath, not merely the letter, which is to determine whether it results in expatriation. It is not a mere matter of words. The test seems to be the question whether the oath taken places the person taking it in complete subjection to the state to which it is taken ... so that it is impossible for him to perform the obligations of citizenship to [the country of nationality].133

Taking an oath of allegiance does not necessarily lead to naturalization. Hence, some states, such as Canada and Sudan, make taking an oath or other formal declaration of allegiance to a foreign state a

129. See pp. 929-35 supra.

130. See pp. 920-28 supra.

131. H.R. Doc. No. 326, 59th Cong., 2d Sess. 23 (1906).

132. Roche, The Loss of American Nationality-The Development of Statutory Expatriation, 99 U. PA. L. Rev. 25, 32 (1950).

133. 3 G. HACKWORTH, DigesT OF INTERNATIONAx. LAw 219 (1942) (Secretary Hughes to Frank L. Polk, March 17, 1924). 
ground for withdrawal of nationality only when such an oath would result in the acquisition of the foreign nationality. ${ }^{134}$

Many states view military service in a foreign state as a ground for withdrawal of nationality in certain cases. Since an individual's entry into military service in a foreign state may be either voluntary or involuntary, and since the foreign state in which he serves may or may not be hostile to his state of nationality, great care should be taken in inferring voluntariness on his part. In Nishikawa v. Dulles the United States Supreme Court held that voluntariness should be proved by "clear, convincing and unequivocal evidence."135 While voluntary service in the armed forces of a state hostile to the individual's state of nationality may be clearly inimical to his duty of loyalty, military service in a state friendly to his own is quite a different matter. Similar considerations would also apply to the case of public employment by a foreign government. ${ }^{136}$

Voting in a foreign political election as a ground for loss of nationality is perhaps unique to the practice of the United States. ${ }^{137}$ Justification is sought on the ground that participation in the public affairs of another state involves a political attachment to the foreign state in a manner incompatible with continued allegiance to the United States. The constitutionality of this particular imposition, first sustained by the Supreme Court in Perez v. Brownell, ${ }^{138}$ was rejected in Afroyim v. Rusk.130

In Perez the petitioner, Perez, was a native-born United States national who had resided in Mexico for a number of years and had voted in political elections in Mexico. ${ }^{140}$ Upon his return to the United States, he was ordered excluded by immigration officials on the ground that he had expatriated himself. Perez sought a declaratory judgment that he was a United States national, challenging the gen-

134. Canada, The Citizenship Act of 1952, art. 15(1), Supplement to Laws ConCERning Nationality, supra note 1, at 15, 21; Sudan, The Nationality Act No. 22 of 1957 , art. 12(c), id. at 71,73 .

135. 356 U.S. 129,135 (1958).

136. See S. Greenleigh \& R. Margenau, supra note 1, at 245-49; Harvard Research, supra note 1 , at 104 .

137. Section 349(a)(5) of the Immigration and Nationality Act of 1952 (as amended) provides:

From and after the effective date of this Act a person who is a national of the

United States whether by birth or naturalization, shall lose his nationality by-

....

(5) voting in a political election in a foreign state or participating in an election or plebiscite to determine the sovereignty over foreign territory, ...

8 U.S.C. $\$ 1481(1970)$.

138. 356 U.S. 44 (1958).

139. 387 U.S. 253 (1967).

140. Perez was a dual national of both the United States and Mexico and had resided in Mexico apparently to avoid military service in the United States. 
eral proposition that the United States could apply a doctrine of "constructive volition" in depriving him of his nationality. The Supreme Court, by a five-to-four vote, upheld the Congress in withdrawing nationality from a native-born national for having voted in the political elections of a foreign country. Speaking for the majority, Mr. Justice Frankfurter stated that the congressional power to control and regulate foreign affairs includes the necessary competence to expatriate any United States national for voting in foreign political elections. Because the power over foreign affairs involves more than "the maintenance of diplomatic relations . . . and the protection of American citizens," the government "must also be able to reduce to a minimum the frictions that are unavoidable in a world of sovereigns sensitive in matters touching their dignity and interests."141 Harmonious relations with other states would be jeopardized

when a citizen of one country chooses to participate in the political or governmental affairs of another country. The citizen may by his action unwittingly promote or encourage a course of conduct contrary to the interests of his own government; moreover, the people or government of the foreign country may regard his action to be the action of his government, or at least as a reflection if not an expression of its policy. ${ }^{142}$

Afroyim v. Rusk ${ }^{143}$ involved a naturalized American citizen who was denied a United States passport on the ground that he had expatriated himself by voting in an Israeli legislative election. The central issue was the same as in Perez. In reaffirming the view that United States citizenship could be lost only "by the voluntary renunciation or abandonment by the citizen himself,"144 Mr. Justice Black, speaking for a majority of five, rejected the notion that Congress has any general power, explicit or implicit, to denationalize, as was suggested by Perez. He emphasized that "the people are sovereign and the Government cannot sever its relationship to the people by taking

141. 356 U.S. 44,57 (1958).

142. Id. at 59. Mr. Justice Frankfurter further stated:

The critical connection between this conduct and loss of citizenship is the fact that it is the possession of American citizenship by a person committing the act that makes the act potentially embarrassing to the American Government and pregnant with the possibility of embroiling this country in disputes with other nations. The termination of citizenship terminates the problem. Moreover, the fact is not without significance that Congress has interpreted this conduct, not irrationally, as importing not only something less than complete and unswerving allegiance to the United States but also elements of allegiance to another country in some measure, at least, inconsistent with American citizenship.

Id. at 60-61.

143. 387 U.S. 253 (1967).

144. Id. at 266. 
away their citizenship." 145 Citizenship, he continued, "is no light trifle to be jeopardized any moment Congress decides to do so under the name of one of its general or implied grants of power." ${ }^{146} \mathrm{He}$ concluded by pointing out that the decision of the Court

does no more than to give to this citizen that which is his own, a constitutional right to remain a citizen in a free country unless he voluntarily relinquishes that citizenship. ${ }^{147}$

Nationality is sometimes withdrawn, in an expression of policies converse to those involved in the "genuine link" requirement for naturalization, if a national has continuously resided abroad over an extended period, normally ranging from two to 10 years. ${ }^{148}$ Though it is most often made applicable to naturalized nationals, in some countries this policy applies to all nationals, by birth or naturalization. ${ }^{\mathbf{4 9}}$ As was observed decades ago:

It is difficult to see why a person who becomes permanently established in a foreign country and identified with the life of the community in which he lives, should be allowed to continue to carry the badge of allegiance of a country with which he has little or no effective contact. ${ }^{150}$

Nevertheless, special care is again required in inferring consent to expatriation by the mere fact of protracted residence abroad, especially in view of the diversity in the requirements of length of stay and the growing frequency of transnational interactions.

With reference to the effect of marriage on the wife's nationality, national laws vary widely. ${ }^{151}$ Just as a woman may automatically or by certain action acquire the nationality of her alien husband upon marriage, she may automatically or by certain action lose her original nationality as a consequence of marriage to a foreign national. ${ }^{152}$ For the sake of family unity and undivided allegiance, in most states a woman automatically lost her original nationality and acquired instead her husband's upon marriage to a foreign national. The loss of nationality was also justified on a theory of implied consent-i.e., a woman, in marrying an alien, "consents" to abandon her original

145. Id. at 257.

146. Id. at $267-68$.

147. Id. at 268 .

148. See Harvard Research, supra note 1, at 104-05.

149. See United Nations, A Study of Statelessness 139 (1949); P. Weis, supra note

1 , at 123; Hudson, supra note 1 , at 18.

150. Sandifer, supra note 45 , at 278.

151. See pp. $922-23$ supra.

152. See Nationality of Markied Women, supra note 66, at 8-18, 29-125. 
nationality. This theory of implied consent was formulated in the famous case, Mackenzie $\dot{v}$. Hare, ${ }^{153}$ where the United States Supreme Court held that the marriage of an American woman to a British subject resulted in the loss of her United States nationality because she "voluntarily entered into [the marriage], with notice of the consequences."154

More recently, however, many states have ceased imposing automatic loss of a woman's original nationality upon marriage to an alien. ${ }^{155}$ This trend reflects in part dissatisfaction with the fiction of implied consent and in part contemporary concern about discrimination. It is in keeping with contemporary demands for the protection of the human person, as previously noted, that a woman national retain her nationality upon marriage to an alien unless she explicitly and voluntarily expatriates herself.

The nationality laws of states with respect to minor children have not been uniform. Conversely to the acquisition of nationality, a minor's nationality may be withdrawn upon the foreign naturalization of his father or widowed mother. ${ }^{156}$ Though the primary rationale is again the unity of family allegiance, genuine consent on the minor's part, if he is capable of such consent, may be missing. This was observed in Perkins v. Elg, ${ }^{157}$ in which the United States Supreme Court held that the American-born child of naturalized parents, who later resumed their former nationality and took her with them to Sweden, had not lost her nationality. In the words of Chief Justice Hughes,

Expatriation is the voluntary renunciation or abandonment of nationality and allegiance. It has no application to the removal from this country of a native citizen during minority. In such a case the voluntary action which is of the essence of the right of expatriation is lacking. ${ }^{15 s}$

Hence, it appears that the trend in practice is toward the retention of the minor's nationality after the foreign naturalization of his parents, even if he may find himself in possession of multiple nationality. If, however, the minor must automatically lose his nationality upon the foreign naturalization of his parents, many commentators increas-

I53. 239 U.S. 299 (1916).

154. Id. at 312.

155. Nationality of Married Women, supra note 66, at 122-25.

156. See S. Greenleigh \& R. Margenau, supra note 1, at 265-71; Sandifer, supra note 45, at 269-71; Harvard Research, supra note 1, at 105-06.

157. 307 U.S. 325 (1939).

158. Id. at 334 . 
ingly urge that the minor be accorded a right of option regarding his nationality upon attaining majority. ${ }^{150}$

\section{Withdrawal Without Consent as Punishment}

It is sometimes asserted that the state has the unlimited competence to withdraw nationality. In the words of Manley Hudson,

In principle, the power of States to cancel or withdraw nationality is, in the absence of treaty obligations, not limited by international law .....$^{160}$

In practice states have acted only on certain relatively restricted grounds. Question has been raised about the permissibility of withdrawal even upon these grounds. Within the United States it is increasingly urged that the withdrawal of nationality as a sanction for inimical conduct having no particular relation to the common interests of states in the management of people may be "cruel and unusual punishment" and, hence, unconstitutional. ${ }^{161}$ Enquiry is equally relevant whether international law does, or should, tolerate so extreme a sanction which serves no purpose in securing the common interests of states.

The grounds upon which states seek in contemporary times to impose loss of nationality as an internal sanction may be summarized under three headings:

(a) crimes against the state, including evasion of military service or desertion from the armed forces in time of war;

(b) hostile political affiliations and activities; and

(c) possession of certain racial, ethnic, or religious characteristics.

We briefly examine each of these grounds:

It is not uncommon for states to impose loss of nationality for conviction of crimes regarded as serious attacks upon the state. Some conduct is regarded as so inimical to the security of the basic values of the community that it is incompatible with continued enjoyment of the benefits and discharge of the responsibilities of community membership. ${ }^{162}$ The range of conduct sometimes so characterized includes

159. Cf., e.g., S. Greenleigh \& R. Margenaur, supra note 1, at 269-71; Sandifer, supra note 45 , at $269 \cdot 71$; Harvard Research, supra note 1 , at 105-06.

160. Hudson, supra note 1 , at 10.

161. The Eighth Amendment of the Constitution provides:

Excessive bail shall not be required, nor excessive fines imposed, nor cruel and unusual punishments inflicted.

162. See S. Greenleigh \& R. Margenau, supra note 1, at 218-23. 
treason, desertion from the armed forces, and evasion of the military draft. The Soviet Union at an early date imposed denationalization and expulsion upon individuals convicted of being "enemies of the toiling masses."103

Within the United States it has recently been questioned whether denationalization is an appropriate sanction for desertion or evasion of military service. In Trop $v$. Dulles, ${ }^{164}$ the Supreme Court declared that depriving a citizen of nationality on the basis of a court-martial conviction for his desertion in time of war, when he had been absent from his duty less than a day and had willingly surrendered, was "cruel and unusual punishment" in violation of the Eighth Amendment. Speaking for a majority of five, Chief Justice Warren observed at the outset that "[d]esertion in wartime, though it may merit the ultimate penalty, does not necessarily signify allegiance to a foreign state."165 "Citizenship," he continued,

is not a license that expires upon misbehavior. The duties of citizenship are numerous, and the discharge of many of these obligations is essential to the security and well-being of the nation. . . . But citizenship is not lost every time a duty of citizenship is shirked. And the deprivation of citizenship is not a weapon that the Government may use to express its displeasure at a citizen's conduct, however reprehensible that conduct may be. ${ }^{100}$

Emphasizing that denationalization is entirely different in character and quality from the traditional modes of criminal punishment, including even the death penalty, ${ }^{167}$ the Chief Justice declared that denationalization as a punishment is forbidden by the Eighth Amendment and, hence, unconstitutional. He stated:

There may be involved no physical mistreatment, no primitive torture. There is instead the total destruction of the individual's status in organized society. It is a form of punishment more primitive than torture, for it destroys for the individual the political existence that was centuries in the development. ${ }^{108}$

Similarly, in Kennedy v. Mendoza-Martinez, ${ }^{160}$ the Supreme Court declared unconstitutional a statute purporting to denationalize persons

163. U.S S.R., Decree of April 22, 1931, reprinted in T. TARAcouzio, The SovieT UNION AND INTERNATIONAL LAW 121 (1935).

164. 356 U.S. 86 (1958).

165. Id. at 92 .

166. Id. at $92-93$.

167. Id. at $93-100$.

168. Id. at 101-02.

169. 372 U.S. 144 (1963). 
who left or remained outside the United States to evade military service, ${ }^{170}$ finding such measures to be cruel and unusual punishment.

A paradoxical case is Kawakita $v$. United States, ${ }^{171}$ in which the petitioner would have benefited if he could have been regarded as denationalized. He was a native-born national of the United States and a national of Japan by virtue of Japanese parentage and had been convicted of treason, with a death sentence, for having mistreated American prisoners-of-war in Japan. He contended that he could not be tried, much less convicted of treason, by the United States because he had expatriated himself from the United States, as evidenced by his use of a Japanese passport during the war, his employment by the Japanese government, his acceptance of labor papers from the Japanese. government, and the entry of his name in the Japanese Koseki (a family census register). The Supreme Court found the implications of his alleged acts of expatriation ambiguous and insufficient. ${ }^{172}$ The petitioner placed special emphasis on the entry of his name in the Koseki, but the Court held that, since he was born a dual national, this entry did not constitute a foreign naturalization signifying renunciation of his American citizenship, but "a reaffirmation of an allegiance to Japan which already exists." 173 The conviction of treason was thus sustained.

A no less paradoxical case, but with a converse twist, is Kuhn $v$. Custodian of Enemy Property, ${ }^{174}$ involving a German national who had moved to Norway in 1911 and had lived there since that time. Because of his refusal to return to Germany upon the outbreak of World War I, his German nationality was withdrawn under German law. At the end of World War II he was treated as a German national and his assets were sequestered as enemy property by the Norwegian government. The Supreme Court of Norway held that, although the appellant was unable to prove conclusively his loss of German nationality, the court would certainly take judicial notice of the German

170. Nationality Act of 1940. $\S 401(j)$, ch. 418, 58 Stat. 746 (1944), provided:

(a) From and after the effective date of this chapter a person who is a national

of the United States whether by birth or naturalization, shall lose his nationality by-

(i0) departing from or remaining outside of the jurisdiction of the United States in time of war or during a period declared by the President to be a period of national emergency for the purpose of evading or avoiding training and service in the military, air, or naval forces of the United States. For the purposes of this paragraph failure to comply with any provision of any compulsory service laws of the United States shall raise the presumption that the departure from or absence from the United States was for the purpose of evading or avoiding training and service in the military, air, or naval forces of the United States.

171. 343 U.S. 717 (1952).

172. Id. at $722-23$.

173. Id. at 724 .

174. [1951] I.L.R. 262 (Supreme Court, Norway 1951). 
draft evasion law. Accordingly, he was found to be a stateless person, rather than a German national, and the sequestration of his property was declared illegal.

Deprivation of nationality for hostile political affiliations and activities has been characterized as "a twentieth century phenomenon."175 The affiliations and activities to which reference is here made differ from those discussed immediately above in that, though they may sometimes border on the criminal, they are not always categorized as crimes and punished by criminal sanctions. Though the ancient world knew banishment for political activities, ${ }^{176}$ this particular form of punishment was relatively rare before World War I. After that war nationality was frequently deprived on such grounds as "disloyalty or disaffection, acts prejudicial to the State or its interests, collaboration with the enemy, [and] advocacy of subversive activities."17t

The most far-reaching denationalization measures were those undertaken in Russia, in the wake of the Bolshevik Revolution, first by the All-Russian Soviet Socialist Republic and then by the Union of Soviet Socialist Republics. ${ }^{178}$ On December 15, 1921, the All-Russian Government issued the following decree:

1. Persons of the under-mentioned categories who remain outside the confines of Russia after the publication of the present decree are deprived of the rights of Russian citizenship:

(a) Persons having resided abroad uninterruptedly for more than five years, and not having received before June 1, 1922, foreign passports or corresponding certificates from representatives of the Soviet Government.... .

(b) Persons who left Russia after November 7, 1917, without the authorization of the Soviet authorities.

(c) Persons who have voluntarily served in armies fighting against the Soviet authority, or who have in any way participated in counter-revolutionary organizations.

(d) Persons having had the right to opt for Russian citizenship and not having exercised that right within the period prescribed for option.

175. S. Greenleigh \& R. Margenau, supra note 1, at 286.

176. See P. Wers, supra note 1 , at 122 .

177. Id. at 124 .

178. For a critical comment, see Williams, Denationalization, 8 BRIT. Y.B. INT'L L. 45 (1927). 
(e) Persons not included under paragraph (a) of this section, who are residing abroad and who shall not have registered themselves at foreign representations of the R.S.F.S.R. within the period prescribed .... ${ }^{178}$

In 1924, the Soviet government adopted a new law, confirming the forfeitures of nationality under prior legislation and denationalizing all Russians abroad who failed to return upon request by competent Soviet officials. ${ }^{180}$ These denationalization measures were obviously aimed at Russian nationals who had opposed the Bolshevik regime or were suspected to be so opposed. The net effect was an unprecedented mass denationalization of some two million people, ushering in a tragic era of refugees. ${ }^{181}$

Following the Russian example, other states (e.g., Italy, Turkey, and Germany) resorted to denationalization on political and other grounds on a wide scale. ${ }^{182}$ After World War II several Eastern European states prescribed denationalization for any person, if abroad, committing "any act prejudicial to the national and state interests."183 Confused by continuing expectations of violence and cold war ideological conflict, even the United States is not immune from this syndrome, as symbolized by the enactment of the Expatriation Act of $1954,{ }^{184}$ purporting to denationalize individuals who advocate the overthrow of the government in a manner proscribed by the Smith Act. ${ }^{185}$ Since membership in the Communist Party per se had been

179. R. Flournoy \& M. Hudson, supra note 1 , at 511 .

180. Decree No. 202 of October 29, 1924, reprinted in id. at 511-14.

181. See E. Kulischer, Europe on the Move: War and Population Changes 19171947 (1948); 2 F. Norwood, supra note 15, at 270-75; J. Simpson, The Refugee Problem: REPORT OF A SURVEY (1939).

182. See Preuss, International Law and Deprivation of Nationality, 23 Gro. L.J. 250, 265.67 (1935).

183. Albania, Nationality Act No. 377 of 16 December 1946, art. 14, LAws CoNCERnING Nationality, supra note 1 , at 4, 6. See also Poland, Nationality Act of 8 January 1951, art. 12(b), id. at 386, 388; Yugoslavia, Nationality Act No. 370/331 of 1 July 1946, art. 16, id. at 554,557 .

184. 8 U.S.C. $\$ 1481(a)(9)(1970)$, provides:

(a) From and after the effective date of this chapter a person who is a national of the United States whether by birth or naturalization, shall lose his nationality by-

(9) committing any act of treason against, or attempting by force to overthrow, or bearing arms against, the United States, violating or conspiring to violate any of the provisions of section 2383 of Title 18, or willfully performing any act in violation of section 2385 of Title 18, or violating section 2384 of Title 18 by engaging in a conspiracy to overthrow, put down, or to destroy by force the Government of the United States, or to levy war against them, if and when he is convicted thereof by a court martial or by a court of competent jurisdiction.

185. The Smith Act, named after its sponsor, Congressman Howard W. Smith of Virginia, was enacted by Congress in 1940, as Title I of the Alien Registration Act, ch. 439,54 Stat. 670 . Its principal substantive provisions, now incorporated in 18 U.S.C. $§ 2385$ (1970), read as follows: 
held to be a violation of the Smith Act, ${ }^{186}$ the potential threat of denationalization to all American Communists was apparent. Although the constitutionality of this enactment has not yet been tested, the response to it was prompt and critical. Shortly after its passage, two students wrote a powerful Note entitled "The Expatriation Act of 1954,"187 later acclaimed as "pioneering and remarkably prophetic" and having "an unmistakable impact on subsequent Supreme Court expressions," 188 cogently observing that the Act's sanctions would be cruel and unusual punishments in violation of the Eighth Amendment and thus unconstitutional. ${ }^{189}$ They further observed that the Expatriation Act "would almost undoubtedly be held void under international law,"190 since "the use of denationalization as a punishment is diametrically opposed to the trend of international law towards a greater protection of human rights." ${ }^{191}$ The authors concluded that

the Act was not a sober response to the demands of national policy, but rather was enacted primarily to vent the nation's hatred of citizens who have forsaken their native country by adopting

Whoever knowingly or willfully advocates, abets, advises, or teaches the duty, necessity, desirability, or propriety of overthrowing or destroying the government of the United States or the government of any State, Territory, District or Possession, thereof, or the government of any political subdivision therein, by forcc or violence, or by the assassination of any officer of any such government; or

Whoever, with intent to cause the overthrow or destruction of any such government, prints, publishes, edits, issues, circulates, sells, distributes, or publicly displays any written or printed matter advocating, advising, or teaching the duty, necessity, desirability, or propriety of overthrowing or destroying any government in the United States by force or violence, or attempts to do so; or

Whoever organizes or helps or attempts to organize any society, group, or as. sembly of persons who teach, advocate, or encourage the overthrow or destruction of any such government by force or violence; or becomes or is a member of, or affiliates with, any such society, group, or assembly of persons, knowing the purposes thereof-

Shall be fined not more than $\$ 20,000$ or imprisoned not more than twenty years, or both, and shall be ineligible for employment by the United States or any department or agency thereof, for the five years next following his conviction.

If two or more persons conspire to commit any offense named in this section, each shall be fined not more than $\$ 20,000$ or imprisoned not more than twenty years, or both, and shall be ineligible for employment by the United States or any department or agency thereof, for the five years next following his conviction.

As used in this section, the terms "organizes" and "organize," with respect to any society, group, or assembly of persons, include the recruiting of new members, the forming of new units, and the regrouping or expansion of existing clubs, classes, and other units of such society, group, or assembly of persons.

186. Cf. 1 T. Emerson, D. Haber \& N. Dorsen, Political and Civil Rights in thl UNITED States 98-147 (student ed. 1967). See, e.g., Scales v. United States, 367 U.S. 203 (1961).

187. Note, The Expatriation Act of 1954, 64 YALE L.J. 1164 (1955). The two students were Norbert A. Schlei and Stephen J. Pollak, each of whom was to become an assistant attorney general of the United States.

188. Gordon, The Citizen and the State: Power of Congress to Expatriate American Citizens, 53 GEO. L.J. 315, 344 (1965).

189. Note, supra note 187 , at $1187-94$.

190. Id. at 1196 .

191. Id. at 1197. 
communism. Actually, democracy and anti-communism would be better strengthened by repeal of the Expatriation Act and reliance upon conventional sanctions to deter and punish subversion. ${ }^{102}$

Denationalization on racial, ethnic, religious, or other related grounds is particularly notorious because of its close association with Nazi and fascist atrocities. ${ }^{103}$ In pursuit of its racial policy, the Hitler government first, in 1933, denaturalized a large number of naturalized citizens, primarily Jews, and then, in 1941, denationalized all German Jews residing abroad. Confiscation of property accompanied forfeiture of nationality. The measures of denationalization were undertaken as part of the National Socialist Program outlined in 1920, pursuant to which "[o]nly those who are members of the nation can be citizens of the State. Only those of German blood, irrespective of religion, can be members of the German nation. No Jews, therefore, can be a member [sic] of the nation. . . . All further immigration of non-Germans is to be prevented. We demand that all non-Germans who have migrated to Germany since August 2, 1914, be compelled to leave the Reich at once." ${ }^{104}$ The underlying racist theory was that Aryans alone were capable of "heroic" deeds and hence epitomized the German nation, while non-Aryans, regarded as an alien and unassimilable race, were to be excluded from German society. ${ }^{105}$

On July 14, 1933, the Nazi government proclaimed that "[n]aturalizations which have taken place between November 9, 1918 and January 30,1933 may be revoked, if the naturalization is considered undesirable." 106 Who was to be considered undesirable was made clear by a supplementary ordinance, stating that "there came especially under consideration for the revocation of naturalization: (a) Eastern Jews, unless they have fought at the front on the side of Germany during the World War, or have rendered important services to German interests . . . " 197 Because of this and other anti-Semitic measures a mass exodus of Jews ensued and by the fall of 1941 few Jews remained in Germany. ${ }^{19 s}$ A new decree, issued on November 15, 1941, denationalized all Jews residing abroad or leaving Germany after that date

192. Id. at 1200 .

193. See H. Santa Cruz, Racial Discrimination 244-96, U.N. Doc. E/CN.4/Sub.2/ $307 /$ Rev.1 (1971); Preuss, supra note 182 .

194. Preuss, supra note 182, at 251.

195. See H. SANTA CRUZ, supra note 193, at 247-52.

196. Preuss, supra note 182, at 250.

197. Id. at 252 .

198. See M. Vishnik, The Legal Status of Stateless Persons 24-33 (1945). 
and confiscated all of their assets. ${ }^{199}$ Denationalization was extended not only to those who had emigrated from Germany during the Third Reich but also to Jews of German nationality who had never set foot in Germany. Included also were the Jewish wives and children of all such nonresident Germans. ${ }^{200}$ The satellite countries of the Axis and those under its domination, Hungary and Rumania, for example, ${ }^{201}$ undertook similar measures against Jews. In Italy, the fascist government revoked all naturalization certificates issued to Jews after January 1, 1919, by the decree of December 17, 1938.202

Following World War II, in the wake of the Nazi holocaust, Czechoslovakia imposed loss of nationality en masse upon persons of the German and Hungarian "races"; Poland and Yugoslavia imposed similar sanctions upon persons of the German "race." Pursuant to the Potsdam Agreement persons of the German "race" were expelled to Germany. ${ }^{203}$

Some states assert additional grounds or wider powers in imposing loss of nationality upon naturalized nationals, as distinguished from born nationals. ${ }^{204}$ It is a common practice to cancel a naturalization certificate upon discovery of fraud or misrepresentation in the procurement of such certificate. ${ }^{205}$ Extended residence abroad, where it is asserted as a ground for deprivation of nationality, is directed mostly toward naturalized nationals. ${ }^{206}$ In the context of denationalization, states often require naturalized nationals to comply with a higher standard of loyalty. ${ }^{207}$ Within the United States, the prohibition of involuntary withdrawal of nationality applies to naturalized citizens

199. See Abel, Denationalization, 6 MOdern L. Rev. 57, 59-61 (1942).

200. Id. at 60 .

201. See P. Meyer, et al., The Jews in the Soviet Satellites 384, 500 (1953).

202. See C. Roth, The History of the Jews of ITALy 524-27 (1946).

203. The relevant provision in the Protocol of Proceedings approved at Berlin (Potsdam) August 2, 1945, reads as follows:

The three governments [U.S., U.K., and U.S.S.R.], having considered the question in all its aspects, recognize that the transfer to Germany of German populations, or elements thereof, remaining in Poland, Czechoslovakia and Hungary, will have to be undertaken. They agree that any transfers that take place should be effected in an orderly and humane manner.

3 Treaties and Other International Agreements of the United States of America, 1776-1949, at 1207, 1220 (C. Bevans comp. 1969).

204. See National Legislation Concerning Grounds for Deprivation of Nationality,

U.N. Doc. A/CN.4/66 (1953) (memorandum prepared by Ivan S. Kerno).

205. See United States v. Genovese, 133 F. Supp. 820 (D.N.J. 1955); Maylotl \& Crystal, The Scheiderman Case: Two Views, 12 Geo. Wash. L, Rev. 215 (1944); Note, Aliens: Denaturalization for Fraud, 35 CAlif. L. REv. 449 (1947).

206. See National Legislation Concerning Grounds for Deprivation of Nationality, supra note 204, at 3. As Justice Douglas stated in Schneider v. Rusk, 377 U.S. 163, 169 (1964),

living abroad, whether the citizen be naturalized or native born, is no badge of lack of allegiance and in no way evidences a voluntary renunciation of nationality and allegiance. It may indeed be compelled by family business, or other legitimate reasons.

207. See National Legislation Concerning Grounds for Deprivation of Nationality, supra note 204. 
as well as natural-born citizens. In Schneider $v . R u s k,{ }^{208}$ the Supreme Court declared invalid the congressional enactment that authorized denaturalization of naturalized citizens who returned for more than three years to the country of their birth or former nationality. In the words of Justice Douglas,

This statute proceeds on the impermissible assumption that naturalized citizens as a class are less reliable and bear less allegiance to this country than do the native born. This is an assumption that is impossible for us to make. . . . A native-born citizen is free to reside abroad indefinitely without suffering loss of citizenship. The discrimination aimed at naturalized citizens drastically limits their rights to live and work abroad in a way that other citizens may. It creates indeed a second-class citizenship. ${ }^{209}$

Despite insistence by some distinguished authors, such as Manley Hudson ${ }^{210}$ and Paul Weis, ${ }^{211}$ that international law imposes no limitation upon the competence of states to deprive individuals of nationality, general community expectations would today appear to be moving toward restricting such allegedly "unlimited" competence. Though the views of Hudson and Weis may accurately reflect the expectations of the past, they certainly do not represent community expectations of the present and probable future. Even historically, international law would appear to have established some restraints and, as the contemporary concern for human rights becomes more intense, additional restraints on such competence will evolve. It has long been agreed that a state could not deprive individuals of nationality and then expel them to other states. The fundamental community policy of minimizing statelessness has had general and intensifying support. The emerging peremptory norm (jus cogens) of nondiscrimination will, as previously noted, make unlawful many types of denationalization. In sum, the whole complex of more fundamental policies for

208. 377 U.S. 163 (1964). See generally Note, Constitutional Limitations on the Naturalization Power, 80 YALE L.J. 769 (1971).

209. 377 U.S. at 168-69. By way of contrast, in Rogers v. Bellei, 401 U.S. 815 (1971), the Supreme Court held that Congress can provide for denationalization of a United States national who is born abroad to an American parent, who is not naturalized in the United States, and who fails to reside in the United States for five years between the ages of 14 and 28. In the opinion of the Court, the Fourteenth Amendment is not applicable to this type of national. The Court indicated its readiness to sustain conditions that are "not unreasonable, arbitrary, or unlawful." Id. at 831. Four dissenting Justices found no basis for distinguishing nationals who acquire their nationality by birth abroad to an American parent from those who acquire it by being born or naturalized in the United States. For comments on this decision, see Gordon, The Power of Congress to Terminate United States Citizenship-A Continuing Constitutional Debate, 4 CoNN. L. REv. 611 (1972); Ulman, Nationality, Expatriation and Statelessness, 25 AD. L. REv. 113 (1973).

210. Hudson, supra note 1 , at 10.

211. P. WEIs, supra note 1 , at 126-29. 
the protection of human rights, as embodied, for instance, in the United Nations Charter, the Universal Declaration of Human Rights, the International Covenants on Human Rights and other related instruments and programs, global as well as regional, may eventually be interpreted to forbid use of denationalization as a form of "cruel, inhuman and degrading treatment or punishment."212 Decisions about nationality are as much within the reference of human rights prescriptions as any other decisions.

The principle that one state could not by denationalization force individuals upon another state was established before any serious concern for human rights figured significantly in the international law about nationality. Writing nearly half a century ago, Sir John Fischer Williams stated that

while positive international law does not forbid a state unilaterally to sever the relationship of nationality so far as the individual is concerned, even if the person affected possesses or acquires no other nationality, still a state cannot sever the tie of nationality in such a way as to release itself from the international duty, owed to other states, of receiving back a person denationalized who has acquired no other nationality, should he be expelled as an alien by the state where he happens to be. ${ }^{213}$

Similarly, as urged by an advocate in a famous case,

it was a universally recognized principle of international law that a State could not simply deprive of their nationality citizens who are out of sympathy with the regime and so force them on other States. 214

212. See The Universal Declaration of Human Rights, art. 5:

No one shall be subjected to torture or to cruel, inhuman or degrading treatment or punishment.

U.N. Human Rights Instruments, supra note 70, at 1.

The International Covenant on Civil and Political Rights, art. 7 , reads:

No one shall be subjected to torture or to cruel, inhuman or degrading treatment or punishment. In particular, no one shall be subjected without his free consent to medical or scientific experimentation.

Id. at 9 .

The European Convention on Human Rights, art. 3, states:

No one shall be subjected to torture or to inhuman or degrading treatment or punishment.

BAsIc Documents, supra note 98, at 126.

The American Convention on Human Rights, art. $5(2)$, provides:

No one shall be subjected to torture or to cruel, inhuman, or degrading punishment or treatment. All persons deprived of their liberty shall be treated with respect for the inherent dignity of the human person.

Id. at 211 .

213. Williams, supra note 178 , at 61 .

214. Lempert v. Bonfol, [1933-1934] Ann. Dig. 290, 292 (No. 115) (Federal Tribunal, Switzerland). See p. 954 infra. 
The perverse reasoning underlying this humane law was that a state has the sovereign competence to control and regiment people within its territory, of which "the power of expulsion" is an essential component. ${ }^{215}$ If one state should be at liberty to render stateless its nationals residing in another state, so it was reasoned, it would encroach upon the right of the state of sojourn and interfere with the exercise of the latter's right to expel aliens. Should the parent state and other states refuse to accept denationalized persons, the state of sojourn would end up bearing the burden of accommodating them. ${ }^{216}$ One of the participants in the International Law Commissions debate has said that "deprivation of nationality involved deprivation of protection; with the implication that the individual affected might become a charge on other states." 217 Indeed, one commentator asked bluntly, "By what right [does one treat] a foreign state as a sort of sewer into which one is entitled to discharge his social detritus?" 218 The paramount policy of this modest restraint on the state's competence was clearly more state-centered than humanistic; it was, nevertheless, a widely accepted and useful restraint.

The policy of minimizing statelessness began to gain recognition after World War I, as the transnational impact of this unfortunate status became pronounced. Before that war stateless persons were relatively few and national frontiers were usually open. The collective denationalizations executed after that war by Russia, Turkey, Germany, Austria, and Italy, however, aroused widespread community concern about the plight of stateless persons. ${ }^{219}$ The policy for the minimization of statelessness manifested itself in the common state practice of making loss of a woman's nationality upon marriage to a foreigner contingent upon acquisition of the husband's nationality. ${ }^{220}$ In almost every international conference on nationality there have been condemnations of denationalization measures causing statelessness. 221

215. Preuss, supra note 182 , at 272.

216. Id. at 269-76.

217. [1953] 1 Y.B. INT'L L. CoMm'N 196, U.N. Doc. A/CN.4/SER.A (1959).

218. Philonenko, Expulsion des Heimatlos, LX JourNal DE DROIT INTERNATIONAL I16I, 1177 (1933), quoted in Preuss, supra note 182, at 273.

219. See A StudY of Statelessness, supra note 149 , at $5-7,34-38,75-122,142-45$; Holborn, The Legal Stalus of Political Refugees, 1920-1938, 32 AM. J. IN r'1. L. 680 (1938).

220. See pp. 922-23, 939-40 supra.

221. Commentators are no less emphatic and unanimous in denouncing denationalization measures without regard for the potential consequences of statelessness. Williams stated emphatically that it was a violation of international law for a state to denationalize any person who had not already acquired a second nationality. Williams, supra note 178, at 52. See also E. Borchard, supra note 5, at 591-92; C. FENwICK, InteRnationat LAw 263 (3d ed. 1948); Abel, supra note 199, at 63; Preuss, supra note 182 , at 274. 
In 1896, the Institute of International Law resolved that

No one can lose his nationality or renounce it unless he shows that he has fulfilled the conditions required to obtain his admission into another state. Denationalization can never be imposed as a penalty. ${ }^{222}$

In the wake of the mass denationalization by the Soviet Union, the International Law Association in 1924 made a broader recommendation, seeking to prohibit denationalization by executive order and thus to protect individuals from being denationalized and expelled. ${ }^{223}$ In 1928, the Institute of International Law strengthened its earlier recommendation by urging states to refrain from actions leading to statelessness. ${ }^{24}$ Reacting to the denationalization measures of the Nazis, the Grotius Society proposed in 1942 that no loss of nationality should be imposed by a state unless and until the individual concerned acquired another nationality. ${ }^{225}$ At the Hague Conference for the Codification of International Law in 1930, reduction and elimination of statelessness was a major concern. Aside from efforts to eliminate provisions imposing statelessness at birth, ${ }^{226}$ the conference adopted provisions seeking to prevent loss of nationality in cases where the individual had not acquired another nationality. The Conference considered in this connection expatriation permits, ${ }^{227}$ the effect of marriage upon nationality, ${ }^{228}$ the effect of naturalization of the parents on the nationality of minor children, ${ }^{22 \theta}$ the effect of legitimation, recognition, and adoption on nationality, ${ }^{230}$ and readmission of former nationals. ${ }^{231}$ The Final Act of the Conference proclaimed:

The Conference is unanimously of the opinion that it is very desirable that States should, in the exercise of their power of regulating questions of nationality, make every effort to reduce as far as possible cases of statelessness, and that the League of

222. J. SCOTt, Resolutions of THE INSTITUTE OF INTERNATIONAL LAw 135 (1916).

223. International Law Association, Report of the Thirty-Third Conference 32 (1925).

224. [1928] ANnuaire de L'INstitut DE Drolt International Public 760

225. 28 Transactions, Grotius Soc'y 157 (1943).

226. See Protocol Relating to a Certain Case of Statelessness, signed April 12, 1930, 179 L.N.T.S. 115.

227. See Convention on Certain Questions Relating to the Conflict of Nationality

Laws, signed April 12, 1930, 179 L.N.T.S. 89, 101 (Art. 7).

228. Id. at 101-03 (Arts. 8-11).

229. Id. at 103 (Arts. 13-15).

230. Id. at 105 (Arts. 16-17).

231. Special Protocol Concerning Statelessness, League of Nations Publications Series 1930.V.6. (C.227.M.114.1930.V.). 
Nations should continue the work which it has already undertaken for the purpose of arriving at an international settlement of this important matter. ${ }^{232}$

This profound concern for the minimization of statelessness has found further concrete expression in the human rights programs in general, in the work of refugee organizations (especially the United Nations High Commissioner for Refugees) in particular, ${ }^{233}$ and, above all, in the adoption of the Convention on the Reduction of Statelessness, ${ }^{234}$ the Convention Relating to the Status of Stateless Persons, ${ }^{235}$ the Convention Relating to the Status of Refugees, ${ }^{236}$ and the Protocol Relating to the Status of Refugees. ${ }^{237}$ The detailed impact of these various conventions will be appraised in our more general discussion of statelessness. ${ }^{238}$

232. Final Act of the Hague Conference, supra note 111, at 14 .

233. See the literature concerning international protection of refugees cited in note 15 stupra. See also Report of the United Nations High Commissioner for Refugees, 27 U.N. GAOR Supp. 12, U.N. Doc. A/8712 (1972).

234. The Convention was adopted and opened for signature on August 30, 1961, by the United Nations Conference on the Elimination or Reduction of Future Statelessness, convened by the Secretary-General of the United Nations under General Assembly resolution 896 (IX) of 4 December 1954. U.N. HuMaN Rights INSTRUMENTs, supra note 70, at 53. As of December 31, 1972, it had not yet come into force. UNITED Nations, Multilateral Treaties in respect of Which the Secretary-General PerFORMS DEFOSITORY Functions: List OF Signatures, Ratifications, ACcessions, etc. as of 31 DECEMBER 1972, at 112, U.N. Doc. ST/LEG/SER.D/6 (1973) [hereinafter cited as Multilateral Treaties 1972].

235. The Convention was adopted by the United Nations Conference on the Status of Stateless Persons, held in New York in September 1954, pursuant to ECOSOC resolution 526A (XVII) of 26 April 1954. It has been in effect since June 6, 1960. U.N. Human Rights Instruments, supra note 70, at 57. As of December 31, 1972, 27 states had ratified or acceded to it; Multilateral Treaties 1972, supra note 234, at 105. For its text, see 360 U.N.T.S. 117; U.N. Human RIghts INSTRUments, supra at 57-63.

236. The Convention was adopted by the United Nations Conference of Plenipotentiaries on the Status of Refugees and Stateless Persons, convened under General Assembly resolution 429 (V) of 14 December 1950 at Geneva in July 1951. It came into force on April 22, 1954. U.N. HumAn Rights INSTRUMENTs, supra note 70, at 63. As of December 31, 1972, 63 states (including the Holy See) had ratified or acceded to the Convention. Multilateral Treaties 1972, supra note 234, at 93-94. For its text, see 189 U.N.T.S. 137; U.N. HUMAN RIGHTS INSTRUMENTs, supra note 70, at 63-70.

237. The draft Protocol was submitted by the United Nations High Commissioner for Refugees to the General Assembly, through the Economic and Social Council, upon the recommendation of the Executive Committee of the Programme of the United Nations High Commissioner for Refugees. The Economic and Social Council noted with approval the draft Protocol in its resolution 1186 (XLI) of 18 November 1966. Later, the General Assembly, noting the draft Protocol in its resolution 2198 (XXI) of 16 December 1966, requested the Secretary-General "to transmit the text of the Protocol to the States mentioned in article $V$ thereof, with a view to enabling them to accede to the Protocol." It became operative" on October 4, 1967. U.N. Human Rights INSTRUMENTS, supra note 70, at 70. For its text, see 606 U.N.T.S. 267; U.N. HUMAN RIGHTS INSTRUMENTs, supra note 70, at 70-72. As of December 31, 1972, 52 states (including the Holy See) had ratified or acceded to the Protocol. Multilateral Treaties 1972, supra note 234, at I14-15. For its legislative history, see Weis, The 1967 Protocol Relating to the Status of Refugees and Some Questions of the Law of Treaties, 42 BRIT. Y.B. INT'L L. 39 (1969).

238. See pp. 960-81 infra. 
It is, however, one thing to condemn a state for acts of denationalization causing statelessness, and quite another to assuage the actual and potential consequences upon the individuals affected. Indeed, "the presumption against statelessness" may in certain circumstances work against the protection of purportedly stateless persons. ${ }^{230}$ "It will not help the individual," Ian Brownlie has observed, "to attribute a nationality which will be nominal and leave him de facto stateless."2-4n Thus, in ascertaining the effect of a particular denationalization measure, decisionmakers have not infrequently sought to interpret and apply the measure and relevant international law in such a manner as to afford individuals "genuine" protection. For example, in Lempert v. Bonfol, ${ }^{241}$ decided by the Swiss Federal Court, the issue was whether the child of a Swiss mother and of a father who had lost his Russian nationality under the Soviet Decree of 1921 was to be deemed a Swiss national. Swiss law provided that the child of a stateless father and a Swiss mother is a Swiss national. The court decided that the child was a Swiss national. In the words of the court,

It is not necessary to express any opinion as to whether the fundamental sovereign right of an individual State to prescribe, according to its own discretion, the conditions of acquisition and of loss of its nationality is in any way limited by considerations of international intercourse; nor as to how far there are to be gathered from international law precise and relevant principles which would permit of the designation of a provision of this nature as inadmissible. For even if this were the case here, this would, in view of the essential nature of international law, as an ordering between States, at the most constitute a breach of duties towards other States prejudiced by the decision in question. The idea of such a breach of duties is practically meaningless if the foreign State has no legal means of compelling the former home State to revoke the deprivation of citizenship and receive back the person affected. It will not alter the fact that he is stateless according to the law which is thus criticised, that is, that his former home State does not regard him as a citizen. ${ }^{242}$

Similarly, in United States ex rel. Schwarzkopf v. Uhl, ${ }^{243}$ the United States Court of Appeals for the Second Circuit decided that an Austrian national residing in the United States when Germany annexed Austria in 1938 was not to be regarded as a German national

239. See Brownlie, supra note 1 , at 337-38.

240. Id. at 338 .

241. [1933-1934] Ann. Dig. 290 (No. 115) (Federal Tribunal, Switzerland).

242. Id. at 293-94.

243. 137 F.2d 898 (2d Cir. 1943). 
and hence sustained his application for a writ of habeas corpus against his detention as an enemy alien. The court found good reason for allowing "former nationals, who have fled from the invader and established a residence abroad, the right of voluntarily electing a new nationality and remaining 'stateless' unt1l they can acquire it." ${ }^{244}$ It added that "an invader cannot under international law impose its nationality upon non-residents of the subjugated country without their consent, express or tacit." 245

In this connection, the observation made by the Supreme Court of Israel in Casperius v. Casperius ${ }^{246}$ is particularly telling. The issue was whether the testator was a German national or a stateless person. The will would be governed by German law in the former case and by Israeli law in the latter. The answer was closely linked to the German denationalization law of $1941 . .^{247}$ In response to the contention that the court could not recognize that law because of its inherent evil, the court said that

this idea, in itself, is sound; however, it is not competent to enable our testator to acquire the nationality of the Nazi State. This is not like any other legal question. Otherwise, we would reach the ridiculous conclusion that, precisely because of the barbarism of the Nazi laws, a man in Israel will have to be regarded as a citizen of that barbarian State. It goes without saying that all the Nazi racial laws stand condemned in our eyes, but we are not prepared to rely on that invalidity in order to recognize, so far as concerns a Jew, the legal nexus with that base régime. Our opinion, therefore, is that despite the unconcealed anti-semitic motives of that law, it was capable of snapping the legal tie between the State and the citizen. ${ }^{248}$

The mass denationalizations upon racial, ethnic, religious, and related grounds under the Nazi and fascist regimes were so shocking that they were widely condemned. While conceding that the state had the competence to denationalize individually, commentators had no difficulty in denouncing such a wholesale discriminatory denationalization as "an abuse of rights"249 and "a violation of international law constituting international liability." 250 In the same vein, Hannah Arendt has observed,

244. Id. at 902 .

245. Id.

246. [1954] I.L.R. 197.

247. See pp. 947-48 supra.

248. [1954] I.L.R. 197, 197-98.

249. See, e.g., H. Lauterpacht, The Function of Law in the International ComMUNITY 300 (1933); 1 L. OPPENHEIM, INTERNATIONAL LAW 280 (6th ed. 1940).

250. Abel, supra note 199 , at 65 . 
One is almost tempted to measure the degree of totalitarian infection by the extent to which the concerned governments use their sovereign right of denationalization $\ldots . .^{251}$

Recently, the German Federal Supreme Court in a number of cases has held the Nazi denationalization decree of 1941 "null and void $a b$ initio" on the theory that because of its arbitrariness and abusiveness it was a "non-law" lacking "the quality of law." 252 "It may have been lex, but it was not jus." ${ }^{253}$ In 1968, the Federal Constitutional Court of Germany emphatically declared that the 1941 decree "violated fundamental principles. It is to so intolerable a degree irreconcilable with justice that it must be considered to have been null and void ex tunc."254

It was in large measure in revulsion against the Nazi and fascist atrocities that the contemporary concern for human rights found concrete expression in the Charter of the United Nations. ${ }^{255}$ Building upon the Charter provisions regarding human rights, the world community has in recent decades moved toward greater protection of human rights, including protection against deprivations of nationality. Foremost among the developing human rights prescriptions is the cardinal principle of nondiscrimination. As Judge Tanaka observed in his dissenting opinion in South West African Cases (Second Phase), 1966, "the norm of nondiscrimination ... on the basis of race has become a rule of customary international law." 256

It will suffice to spotlight some of the more pertinent provisions of international documents. The Charter of the United Nations declares that promotion and encouragement of "respect for human rights and for fundamental freedoms for all without distinction as to race, sex, language, or religion" is one of the major purposes of that organization, ${ }^{257}$ a policy in evidence elsewhere in the Charter. ${ }^{258}$ The first paragraph of Article 2 of the Universal Declaration of Human Rights declares:

251. H. Arend, The Origins of Totalitarianism 278 (1958).

252. Mann, The Present Validity of Nazi Nationality Laws, 89 L.Q. Rev. 194, 199 (1973).

253. Id.

254. Id. at 199-200.

255. See L. Goodrich, E. Hambro \& A. Simons, Charter of the United Nations: Commentary and Documents 34-35, $370-447$ (3d rev. ed. 1969); R. Russell, A History of The United Nations Charter $309-29$ (1958); E. Schwele, HuMan Rights and the Inteknational Community 24-29 (1964); Sohn, A Short History of United Nations Documents on Human Rights, in Commission to Study THE Organization OF PEACE, the United Nations and Human Rights: 18Th Report of the Commission 39, 43-59 (1968).

256. [1966] I.C.J. 284.

257. U.N. CharTer art. I, para. 3.

258. Id. arts. $13(\mathrm{I})(\mathrm{b}), 55,56$. 
Everyone is entitled to all the rights and freedoms set forth in this Declaration, without distinction of any kind, such as race, colour, sex, language, religion, political or other opinion, national or social origin, property, birth or other status. ${ }^{2 \overline{59}}$

Comparable provisions can be found in the International Covenant on Civil and Political Rights, ${ }^{200}$ the International Covenant on Economic, Social, and Cultural Rights, ${ }^{261}$ the European Convention on Human Rights, ${ }^{262}$ and the American Convention on Human Rights. ${ }^{263}$ Of special relevance in the present context are the International Convention on the Elimination of All Forms of Racial Discrimination, ${ }^{264}$ the United Nations Declaration on the Elimination of All Forms of Racial Discrimination, ${ }^{265}$ and the Genocide Convention. ${ }^{266}$

According to the Convention against Racial Discrimination, "States Parties undertake to prohibit and to eliminate racial discrimination in all its forms and to guarantee the right of everyone, without distinction as to race, colour, or national or ethnic origin, to equality before the law, notably in the enjoyment of, [inter alia], the right to nationality." 207 "Particular efforts shall be made," pursuant to the Declaration against Racial Discrimination, "to prevent discrimination based on race, colour or ethnic origin, especially in the fields of, [inter alia], access to citizenship." 268 The policies both against racial discrimination and for the protection of national affiliation deeply infuse the Genocide Convention, which provides:

In the present Convention, genocide means any of the following acts committed with intent to destroy, in whole or in part, a national, ethnical, racial or religious group, as such:

(b) Causing serious bodily or mental harm to members of the group;

259. U.N. Human Rights INStruments, supra note 70, at 1.

260. Id. at $8,9,12$ (Arts. 2(1), 4(1), 26).

261. Id. at 4 (Art. 2, para. 2).

262. Basic Documents, supra note 98 , at 130 (Art. 14).

263. Id. at 210, 218, 219 (Arts. 1(1), 24, 27(1)).

264. The Convention was adopted and opened for signature and ratification by the U.N. General Assembly in its resolution $2106(\mathrm{XX})$ of 21 December 1965. It has been in effect since January 4, 1969. U.N. Human RIGHTS INstrumeNTs, supra note 70 , at 23. For its text, see 660 U.N.T.S. 195; U.N. HuMAN Rights INSTRUMENTs, supra note 70, at 23. 265. The Declaration was adopted by the U.N. General Assembly in its resolution 1904 (XVIII) of 20 November 1963. U.N. HUMAN RIGHTs Instruments, supra note 70, at 21.

266. The Convention on the Prevention and Punishment of the Crime of Genocide was adopted by the U.N. General Assembly in its resolution 260 (III) of 9 December 1948. It has been in effect since January 12, 1951. U.N. HuMAN RIGHTS INSTRUMENTs, supra note 70, at 39. For its text, see 78 U.N.T.S. 277; U.N. HUMAN Rights Instruments, supra note 70 , at 39.

267. U.N. HUMAN Rights INSTRUMENTs, supra note 70, at 24 (Art. 5(d)(iii)).

268. Id. at 22 (Art. 3). 
(c) Deliberately inflicting on the group conditions of life calculated to bring about its physical destruction in whole or in part;

$\ldots .^{269}$

Article 9 of the Convention on the Reduction of Statelessness is particularly direct:

A Contracting State may not deprive any person or group of persons of their nationality on racial, ethnic, religious or political grounds. ${ }^{270}$

It thus appears incontrovertible that denationalization measures based on racial, ethnic, religious, or other related grounds are impermissible under contemporary international law.

Denationalization is equally impermissible as a form of punishment. It may be recalled that both the Universal Declaration of Human Rights and the American Convention on Human Rights contain specific proscription against "arbitrary" deprivation of nationality. ${ }^{271}$ In addition, article 5 of the Universal Declaration of Human Rights provides that "[n]o one shall be subjected to torture or to cruel, inhuman or degrading treatment or punishment."272 Similar provisions are embodied in the principal human rights conventions, including the International Covenant on Civil and Political Rights, ${ }^{273}$ the European Convention on Human Rights, ${ }^{274}$ and the American Convention on Human Rights. ${ }^{275}$ Deprivation of nationality as a measure of punishment may easily be seen as a form of "cruel, inhuman or degrading treatment or punishment."

The policy illuminated by Chief Justice Warren in Trop v. Dulles $s^{270}$ in the context of United States constitutional law is becoming equally authoritative in the international domain. Within their legal systems, states have at their disposal a whole arsenal of criminal sanctions, including fines, imprisonment, and even death, to combat criminal conduct; there is no need for their resorting to denationalization for

269. Id. at 39. On the Genocide Convention, see N. Robinson, Thr Genocide ConVENTION (1960); Reisman, Responses to Crimes of Discrimination and Genocide: An Appraisal of the Convention on the Elimination of Racial Discrimination, 1 DENVER J. INT'L L. \& POLICY 29 (1971).

270. U.N. HuMAN Rights INSTRUMENTS, supra note 70, at 55.

271. See p. 928 supra.

272. U.N. HuMAN Rights INSTRUMENTs, supra note 70, at 1 .

273. Id. at 9 (Art. 7).

274. Basic Documents, supra note 98, at 126 (Art. 3).

275. Id. at 211 (Art. 5(2)).

276. 356 U.S. 86 (1958). 
punishment as such. ${ }^{277}$ In the contemporary world of nation-states, the right to nationality remains in essence "the right to have rights."278 Denationalization as a form of punishment is neither necessary nor proportionate for the purpose of criminal sanction.

In his comprehensive commentary on the application of the European Convention on Human Rights, Fawcett defines "inhuman treatment" as

the deliberate infliction of physical or mental pain or suffering, against the will of the victim, and, when forming part of criminal punishment, out of proportion to the offence.279

Viewed in this light, the interpretation that denationalization as a punishment constitutes a cruel, inhuman treatment or punishment will in all likelihood gain increasing recognition and acceptance. Through such an interpretation and development the unfortunate omission of an explicit provision against deprivation of nationality in the International Covenant on Civil and Political Rights and European Convention on Human Rights may, fortunately, be remedied.280

277. See Note, supra note 187, at 1179-80.

278. The words of Chief Justice Warren eloquently describe what we refer to:

The punishment strips the citizen of his status in the national and international political community. His very existence is at the sufferance of the country in which he happens to find himself. While any one country may accord him some rights, and presumably as long as he remained in this country he would enjoy the limited rights of an alien, no country need do so because he is stateless. Furthermore, his enjoyment of even the limited rights of an alien might be subject to termination at any time by reason of deportation. In short, the expatriate has lost the right to have rights.

This punishment is offensive to cardinal principles for which the Constitution stands. It subjects the individual to a fate of ever-increasing fear and distress. He knows not what discriminations may be established against him, what proscrip. tions may be directed against him, and when and for what cause his existence in his native land may be terminated. He may be subject to banishment, a fate universally decried by civilized people. He is stateless, a condition deplored in the international community of democracies. It is no answer to suggest that all the disastrous consequences of this fate may not be brought to bear on a stateless person. The threat makes the punishment obnoxious.

Trop v. Dulles, 356 U.S. 86, 102 (1958).

279. J. Fawcett, The Application of the European Convention on Human Rights 35 (1969).

Contemporary theories about the sanctioning process raise the question whether there are any acceptable community policies in terms of which "denationalization" might be "proportionate" as a punishment; cf. Dession, Sanctions, Law, and Public Order, I VAND. L. REv. 8 (1947); Dession \& Lasswell, Public Order Under Law: The Role of the Advisor-Draftsman in the Formation of Code or Constitution, 65 YALE L.J. 174 (1955); Comment, Professor George H. Dession's Final Draft of the Code of Correction for Puerto Rico, 71 YALE L.J. 1050 (1962).

280. The denationalization and forcible exile on February 13, 1974, of Alexander I. Solzhenitsyn by the Soviet Union have focused world attention anew upon the enormous human deprivations inherent in denationalization and exile. This action by the Soviet Union was apparently precipitated by the publication in December 1973 in Paris of Solzhenitsyn's latest book, The Gulag Archipelago 1918.1956, a comprehensive, historical exposé of the secret police, prison camp, and terror system in the Soviet 


\section{Claims Relating to Statelessness}

The status of statelessness entails a most severe and dramatic deprivation of the power of an individual. Just as within the state nationality is the "right to have rights," so also on the transnational level nationality is the right to have protection in rights. The stateless person has no state to "protect" him and lacks even the freedom of movement to find a state that is willing to protect him. His participation in the value processes of any territorial community is highly restricted. As aptly stated in the preamble of one Draft Convention, statelessness

often results in suffering and hardship shocking to conscience and offensive to the dignity of man, ...

is frequently productive of friction between States, ...

is inconsistent with the existing principle which postulates nationality as a condition of the enjoyment by the individual of certain rights recognized by international law $\ldots . .^{281}$

Most importantly, nationality is commonly regarded as essential for a state to protect an individual vis-à-vis other entities in the transnational arena. In the words of Oppenheim-Lauterpacht,

Union. The official charge against Solzhenitsyn was that of "systematically performing actions incompatible with being a citizen," a charge apparently regarded as an equivalent of treason. See N.Y. Times, Feb. 14, 1974, at 1, col. 8 (city ed.); id., Feb. 15, 1974, at 1, col. 5 (city ed.); Wash. Post, Feb. 15, 1974, at A24, col. 5.

Some question has been raised about the conformity of the Soviet edict to Soviet law; cf. N.Y. Times, Feb. 14, 1974, at 16, col. I (city ed.); id., Feb. 16, 1974, at 3, col. 1 (city ed.); THE Economist, Feb. 16, 1974, at 18. It is clear nonetheless that the Soviet action is in direct contravention of the emerging general community expectations that denationalization and exile are impermissible as "cruel and unusual punish ment." Both the detailed circumstances attending the denationalization and forcible exile of Solzhenitsyn and their longer-term consequences indicate this conclusion. See TIME, Feb. 25, 1974, at 34-40; Christian Science Monitor, Feb. 14, 1974, at 1, col. 1, at 2, col. I; id., Feb. 15, 1974, at 1, col. 1. In confirmation of Solzhenitsyn's own subjectivities, one of his fictional characters describes exile as "spiritual castration." A. Solzhenitsyn, The First Circle 356 (T. Whitney transl. Bantam ed. 1969). The wave of protest about the world indicates that those subjectivities are not idiosyncratic, but widely shared. It can be added that the emerging human rights norm of nondiscrimination, described above, forbids discrimination not only on grounds of race, color, religion, and sex, but also on grounds of political opinion.

The principle that one state cannot by denationalization force an individual upon other states would, paradoxically, not appear to be available here to serve the cause of humanity. Too many other states have expressed willingness to accept so redoubtable an anti-communist into their own communities. It may be recalled that in 1929 Trotsky suffered the same fate that has now befallen Solzhenitsyn, and the press abounds with rumors of further deprivations. See, e.g., N.Y. Times, Nov. 18, 1973, $\$ 1$, at 12, col. 3; id., Dec. 12, 1973, at 4, col. 4 (city ed.); id., Feb. 14, 1974, at 16, col. 1 (city ed.); id., Feb. 19, 1974, at 3, col. 1 (city ed.); NEwSwEEk, Feb. 25, 1974, at 38.

281. Alternative Convention on the Elimination of Present Statelessness, in Cordova, Third Report on the Elimination or Reduction of Statelessness, [1954] 2 Y.B. INT'I L. CoMM'N 26, 36, U.N. Doc. A/CN.4/81 (1954). 
Since stateless individuals do not own a nationality, the principal link by which they could derive benefits from International Law is missing, and thus they lack protection as far as this Law is concerned. ${ }^{282}$

Thus, a stateless person has been compared to "a res nullius," 283 a "flotsam," 284 a vessel "on the open sea not sailing under the flag of a State,"285 "a caput lupinum,"286 "a bird that flies alone," "an international vagabond." 288 The hardship visited upon a stateless person is dramatically evident in the Dickson Car Wheel Company Case, $^{289}$ in which the Special Claims Commission between the United States and Mexico declared in 1931:

A State ... does not commit an international delinquency in inflicting an injury upon an individual lacking nationality, and consequently no State is empowered to intervene or complain on his behalf either before or after injury. ${ }^{200}$

In short, statelessness means "the loss of a community willing and able to guarantee any rights whatsoever." 291

The powerlessness of the stateless person is most apparent in the limitation upon his freedom of movement, both of egress and of return. Because of widespread, rigorous requirements for travel documents (e.g., a valid passport, an entry visa), a stateless person, lacking necessary documents, usually experiences great difficulty in locating a state willing to receive him. Unable to enter the territory of a state lawfully, he is often compelled to do so clandestinely. His illegal entry continues to haunt him. "He will then," as has been observed, "lead an illegal existence, avoiding all contact with the authorities and living under the constant threat of discovery and expulsion."292 In his presidential address in 1801, Thomas Jefferson said that "[e]very man has a right to live somewhere on the earth";293 a stateless person, however, has no such right.

282. 1 Oppenheim-Lauterpacht, supra note 76 , at 668 .

283. G. SCHWARZENBERGER, INTERNATIONAL LAW 171 (2d ed. 1949).

284. Weis, supra note 122 , at 1073 .

285. 1 Oppenheim-Lauterpacht, supra note 76 , at 668 .

286. H. LAUTERPACHT, supra note 103, at 126.

287. The description from Aristotle is quoted in C. Seckler-Hudson, Statelessness:

With SPECIAL Reference to the United STATEs 244 (1934).

288. The description is by De Lapradelle and Niboyet, quoted in id. at 15 .

289. [1931-1932] Ann. Dig. 228 (No. 115).

290. Id. at 230 n.l.

291. H. ARENDT, supra note 25I, at 297.

292. A Study of STATelessNess, supra note 149, at 20.

293. Quoted in C. SECKLER-Hudson, supra note 287, at 248. 
Other deprivations are visited upon the stateless individual. He is denied general participation, such as voting and office-holding, in the internal power process of any body politic. He often cannot obtain documents certifying his personal status (e.g., age, relationships) because no state is in a position to give that information. He may not be properly protected by the processes of authoritative decision and may be denied access to the courts of any state. He may be subject to taxation and military service in any state where he is found.

Stateless persons are also subjected to deprivations, sometimes in common with other aliens and sometimes more severely, in value processes other than power. The stateless individual may be discriminated against in every territorial community because of his alienage; he is not properly recognized as a person and is thus denied respect. His opportunities for education are more limited; so also are his opportunities to shape enlightenment through the mass media of communication. He is often denied the benefits of public health and other welfare programs. His right to property, to employment, and to engage in business enterprises may be curtailed; certain professions and occupations exclude nonnationals. In the exercise of professional skills a stateless person may be denied the opportunity for fullest expression. $\mathrm{He}$ may encounter a great deal of difficulty in marriage because he cannot obtain authentic documents certifying his status. ${ }^{204}$

The important causes of statelessness quite obviously derive from the formulation and application of the nationality laws of states in contravention of human rights. The traditional myth that the regulation of nationality is a matter within the domestic jurisdiction of states $^{295}$ and the resultant diversity of nationality laws has created many gaps in the conferment of nationality both at birth and subsequent to birth.

Statelessness at birth generally arises from the inadequacy and diversity of nationality laws, which usually employ both jus soli and $j u s$ sanguinis, but not always $j u s$ soli and different versions of $j u s$ sanguinis. The main features of this problem are apparent in a "synop-

294. For descriptions of the plight of stateless persons, see id. at 11-22, 244-53; A Study of Statelessness, supra note 149, at 17-31; A. Mutharika, International Regulation of Statelessness, 1970, at 12-17 (unpublished J.S.D. dissertation, Yale Law School). 295. For a general survey of such views, see $\mathbf{P}$. WEIs, supra note 1 , at 65.94 .

In the well-known Tunis-ilorocco Nationality Decrees case, a more enlightened view was intimated. The court held that nationality could be made a matter of "international concern" by agreement: "The question whether a certain matter is or is not solely within the jurisdiction of a State is an essentially relative question; it depends upon the development of international relations. Thus, in the present state of international law, questions of nationality were, in the opinion of the Court, in principle within this reserved domain." [1923] P.C.I.J., ser. B., No. 4, at 24. 
tic chart of possible sources of statelessness" offered by a United Nations study: ${ }^{296}$

\section{Statelessness at Birth}

A. Children born abroad.

B. Child born in a jus sanguinis country with one parent stateless.
1. In jus sanguinis country of parents of strict jus soli country.

2. In jus sanguinis country from a second or third generation of parents nationals of a jus sanguinis country.

1. Legitimate (Stateless if father stateless).

2. Illegitimate (Stateless if mother stateless).

C. Born in jus sanguinis country of stateless father and mother or without known nationality.

D. Born in jus sanguinis country of unknown parents.

E. Foundlings.

F. Born on ship or aircraft.

1. In high seas.

2. In territorial sea.

3. In foreign port.

4. In air above foreign territory.

G. Born from stateless parents with diplomatic immunity.

Statelessness subsequent to birth, simply put, arises from the fact that a person loses his nationality or nationalities without acquiring another. Loss of nationality may be caused by: (1) explicit, voluntary expatriation; ${ }^{207}$ (2) withdrawal of nationality by the state upon the "constructive" and often fictitious consent of the individual;298 (3) deprivation of nationality as punishment; ${ }^{299}$ and (4) territorial changes. ${ }^{300}$ The United Nations study, cited above, again offers a chart both comprehensive and economic, though using a somewhat different classification from our own, in its indication of potential causes of statelessness after birth:301

296. Cordova, Report on the Elimination or Reduction of Statelessness, [1953] 2 Y.B. INT'L L. CoMm'N 167, 195, U.N. Doc. A/CN.4/64 (1953).

297. See pp. 929-35 supra.

298. See pp. 935.41 supra.

299. See pp. 941-59 supra.

300. Cf. 1 D. O'Connell, State Succession in Municipal. Law and International

LAW 497-528 (1967); P. WEIS, supra note 1, at 139-64; Hudson, supra note 1, at II.

301. Cordova, supra note 296, at 195. 


\section{Statelessness Subsequent to Birth}

I. Inadequacy and Conflict of National Legislations.
A. Effect of marriage 1. Effect of marriage on the national- itself. ity of women.

2. Husband's change of nationality.

3. Dissolution of marriage:

(a) Widow of national;

(b) Invalid or fictitious marriage;

(c) Divorce.

B. Legitimation of illegitimate child.

C. Adoption.

D. Voluntary Renunciation.

E. Change of nationality of the spouse or of a parent.

F. Naturalization of the spouse or of a parent.

(a) As a penalty

(a) Residence abroad of nationalized citizens.

(b) Service in foreign government or armed forces.

(c) Departure abroad.

(d) Evasion of military duties by expatriation or otherwise.

(e) Disloyal attitude or activities.

(f) Aid to enemies.

(g) Naturalization by fraud.

(h) Penal offense of naturalized citizens.

II. Deprivation of nationality

(b) based on: racial, religious, Only if the State of origin deprives of its political nationality; otherwise there is not a $d e$ grounds jure statelessness, but only de facto.

III. Inadequacy of treaties on territorial settlements. 


\section{Minimization of Statelessness}

In a succession of efforts since World War $I$, the international community has sought both to eliminate or reduce statelessness and, by mitigating hardships, to improve the position and treatment of stateless persons. During the era of the League of Nations, the landmark action was the 1930 Hague Conference for the Codification of International Law, which adopted a Convention on Certain Questions Relating to the Conflict of Nationality Laws ${ }^{302}$ and a Protocol Relating to a Certain Case of Statelessness. ${ }^{303}$ Convention provisions relevant to statelessness dealt with a number of matters: expatriation permits, ${ }^{304}$ the nationality of married women, ${ }^{305}$ the nationality of children, ${ }^{306}$ and adoption. ${ }^{30 \tau}$ The Protocol is concerned with the avoidance of statelessness at birth under certain circumstances. ${ }^{308}$ The profound sense of urgency for further work in the minimization of statelessness, though expressed in the Final Act of the Conference, ${ }^{309}$ was not followed up by the League.

Efforts to minimize statelessness were renewed after the founding of the United Nations. In 1947, the Human Rights Commission of the United Nations urged consideration of nationality questions. ${ }^{310}$ This proposal received concrete expression in article 15 of the Universal Declaration of Human Rights of December 1948, which proclaims:

1. Everyone has the right to a nationality.

2. No one shall be arbitrarily deprived of his nationality nor denied the right to change his nationality. ${ }^{311}$

As a first step in clarifying this right, in 1949 the Secretary-General, at the request of the Economic and Social Council, prepared a study on statelessness. ${ }^{312}$ This study called for the universal acceptance of the

302. Signed on April 12, 1930,179 L.N.T.S. 89.

303. Signed on April 12, 1930, 179 L.N.T.S. 115.

304. 179 L.N.T.S. 101 (Art. 7).

305. Id. at 101-03 (Arts. 8-9).

306. Id. at 103-05 (Arts. 13, 16).

307. Id. (Art, 17).

308. Article 1 of the Protocol provides:

In a State whose nationality is not conferred by the mere fact of birth in its territory, a person born in its territory of a mother possessing the nationality of that State and of a father without nationality or of unknown nationality shall have the nationality of the said State.

179 L.N.T.S. 117.

309. Final Act of the Hague Conference, supra note 111 , at 14

310. 6 U N. ECOSOC, Supp. 1, at 13-14, U.N. Doc. E/600 (1947).

311. U.N. HUMAN RIGHTS INSTRUMENTS, supra note 70, at 2. For a brief commentary on this article, see N. Robinson, The Universal Declaration of Human Rights 123-24 (1958); cf. Griffin, The Right of a Single Nationality, 40 TEMP. L.Q. 57 (1966).

312. A Study of Statelessness, supra note 149. 
following two principles: ( 1 ) nationality is to be conferred on every child at birth; (2) no person should lose his nationality during his lifetime unless and until he has acquired a new one. ${ }^{313}$ In August 1950, the Economic and Social Council urged the International Law Commission to prepare at the earliest possible time the necessary draft international convention or conventions for the minimization of statelessness. ${ }^{314}$

From its inception in 1949, the International Law Commission included "nationality, including statelessness" in its list of topics to be considered for codification. ${ }^{315}$ It dealt with this problem from the fourth to the sixth sessions (1952-1954), appointing Professors Manley O. Hudson and Roberto Cordova, successively, as special rapporteurs on the subject. ${ }^{316}$ The Commission decided to focus its attention on the problem of statelessness. On the basis of Professor Cordova's draft Conventions on the Elimination of Future Statelessness and on the Reduction of Future Statelessness ${ }^{317}$ and his annual reports, the Commission adopted the texts of draft Conventions on the Elimination and Reduction of Future Statelessness. ${ }^{318}$ Both drafts were transmitted to governments for comments and, in the light of these, the Commission redrafted some of the articles in 1954..$^{319}$ These two draft conventions were designed to facilitate acquisition of the nationality of a state by virtue of birth within its territory and to avoid the loss of nationality prior to acquisition of another. When the question of statelessness came before the Sixth (Legal) Committee of the General Assembly, some delegates voiced strong objections to the draft Conventions on the ground that they encroached upon the domestic jurisdiction of states in matters of nationality. ${ }^{320}$ Nevertheless, at the recommendation of the Sixth Committee, the General Assembly decided in December 1954, to convene an international conference of plenipotentiaries to conclude a convention for the reduction or elimination of future

313. Id. at 170 .

314. ECOSOC Res, 319B III, 11 U.N. ECOSOC, Supp. 1, at 52, U.N. Doc. E/1849 (1950).

315. Report to the General Assembly, [1949] Y.B. INT'L L. ComM'N 277, 280-81.

316. For the Report submitted by Professor Hudson at the Fourth Session of the International Law Commission in 1952, see Hudson, supra note 1. For the Reports submitted by Professor Cordova, see Cordova, supra note 296; Cordova, Second Report on the Elimination or Reduction of Statelessness, [1953] 2 Y.B. INT'L L. CoMM'N 196, U.N. Doc. A/CN.4/75 (1953); Cordova, supra note 281; Cordova, Report on Multiple Nationality, [1954] 2 Y.B. INT'L L. Comm'N 42, U.N. Doc. A/CN.4/83 (1954).

317. Cordova, supra note 296; Cordova, Second Report, supra note 316.

318. See Report of the International Law Commission Covering the Work of Its

Fifth Session, [1953] 2 Y.B. INT'L L. CoMm'N 200, 220-30, U.N. Doc. A/2456 (1953).

319. See Rehort of the International Law Commission Covering the Work of Its

Sixth Session, [1954] 2 Y.B. INT'L L. CoMM'N 140, 141-48, U.N. Doc. A/2693 (1954).

320. [1954] YEARBoOK OF THE UNITED Nations 418 [hereinafter cited as Y.B.U.N.]. 
statelessness as soon as at least 20 states had communicated to the Secretary-General their willingness to join in such an undertaking. ${ }^{321}$

A sufficient number of states ultimately expressed such willingness and the Conference was finally convened in Geneva during 1959. The Conference, with 35 states participating, adopted provisions designed to reduce statelessness at birth but failed to reach agreement upon how to limit the competence of states to deprive an individual of nationality. ${ }^{322}$ The Conference was reconvened in 1961, with 30 states in attendance. A compromise was reached on the controversial provision regarding deprivation of nationality and the other provisions that had failed adoption in the previous conference were also accepted. The Conference adopted a Convention on the Reduction of Statelessness, which was open for signature in $1962 .^{323}$ As of this writing, the Convention has not yet come into effect. ${ }^{324}$

The Commission on the Status of Women has played a significant role in the minimization of statelessness for married women. A principal source of statelessness is marriage of women to foreign nationals. $^{325}$ As a consequence of the persistent efforts of the Commission, the General Assembly adopted the Convention on the Nationality of Married Women in January 1957. The Convention has been in operation since August 11, 1958. ${ }^{326}$ An earlier regional convention, the Montevideo Convention on the Nationality of Women signed on December 26, 1933, was, however, the first to prescribe the principle of equality of sexes regarding nationality. ${ }^{\mathbf{3 2 7}}$

The foregoing efforts, viewed in sum, are far from inconsequential. They have been directed at the various causes of statelessness and have helped to crystallize expectations for the minimization of statelessness. We briefly discuss the main features of these proposed remedies by reference to each of the causes of statelessness.

\section{(a) Statelessness at Birth}

The important policy for the elimination of statelessness at birth has been succinctly phrased by Manley Hudson in these words:

321. G.A. Res. 896, 9 GAOR Supp. 21, at 49-50, U.N. Doc. A/2890 (1954).

322. See [1959] Y.B.U.N. 413-14; Weis, supra note 122, at 1078-80.

323. See note 234 supra. For a commentary on the Convention, see Weis, supra note 122.

324. See note 234 supra.

325. See pp. $939-40$ supra.

326. See note 70 supra.

327. 6 M. Hudson, International Legislation 589 (1937); Laws Concerning NaTIONALITY, supra note 1 , at 584 . Article 1 of the Convention reads:

There shall be no distinction based on sex as regards nationality, in their legislation or in their practice. 
If no other nationality is acquired at birth, the individual should acquire the nationality of the State in whose territory he is born. ${ }^{328}$

This policy has found authoritative expression in both general and specific formulations of various conventions. The Universal Declaration of Human Rights provides, as we have seen, most generally that "everyone has the right to a nationality." ${ }^{22}$ The International Covenant on Civil and Political Rights, though lacking a nationality provision applicable to everyone, provides that "every child has the right to acquire a nationality." ${ }^{330}$ More specifically, the American Convention on Human Rights states that

[e]very person has the right to the nationality of the state in whose territory he was born if he does not have the right to any other nationality. ${ }^{331}$

These recent developments were of course preceded by certain historic efforts to eradicate statelessness, efforts which attempted to make jus soli and jus sanguinis supplement and reinforce each other. ${ }^{332}$ A provision of critical importance of the 1930 Hague Convention on Nationality, article 15, states:

Where the nationality of a State is not acquired automatically by reason of birth on its territory, a child born on the territory of that State of parents having no nationality, or of unknown nationality, may obtain the nationality of the said State. The law of that State shall determine the conditions governing the acquisition of its nationality in such cases. ${ }^{333}$

According to article 14, the nationality of the state of birth is to be conferred upon a child of unknown parents; once his parentage is established, his nationality will be governed by "the rules applicable in cases where the parentage is known." ${ }^{334} \mathrm{~A}$ foundling is "presumed to have been born on the territory of the State in which it was found." Furthermore, the Protocol Relating to a Certain Case of Statelessness (1930) provides:

In a State whose nationality is not conferred by the mere fact of birth in its territory, a person born in its territory of a mother

328. Hudson, supra note 1 , at 20.

329. U.N. HUMAN Rights INSTRUMENTs, supra note 70, at 2 (Art. 15 (1)).

330. Id. at 12 (Art. 24(3)).

331. Basic Documents, supra note 98, at 217 (Art. 20(2)).

332. See A Study on StAtelessNess, supra note 149, at $145-60$.

333. 179 L.N.T.S. 89, 103.

334. Id. 
possessing the nationality of that State and of a father without nationality or of unknown nationality shall have the nationality of the said State. ${ }^{335}$

Its main purpose was to ensure the conferment of nationality upon a legitimate child or a recognized illegitimate child whose father alone is stateless.

The 1961 Convention on the Reduction of Statelessness ${ }^{336}$ deals with the question of statelessness at birth in articles one to four, reflecting "a compromise between jus soli and jus sanguinis States, not a compromise between the jus soli and jus sanguinis principles." 337 A contracting state is required to "grant its nationality to a person born in its territory who would otherwise be stateless." ${ }^{338}$ However, a contracting state may attach conditions to the conferment of such nationality, including age, residence, and absence of criminal record. ${ }^{339}$ A "child born in wedlock in the territory of a Contracting State, whose mother has the nationality of that State, shall acquire at birth that nationality if it otherwise would be stateless." ${ }^{340}$ A foundling present in the territory of a contracting state is presumed to have been born within that territory and of parents possessing the nationality of that state. $^{341}$ This is a reaffirmation of the similar principle contained in the Hague Convention ${ }^{342}$ and the nationality laws of numerous states. Birth "on a ship or in an aircraft" will be regarded as having occurred "in the territory of the State whose flag the ship flies or in the territory of the State in which the aircraft is registered," irrespec-

335. 179 L.N.T.S. 117 (Art. 1).

336. U.N. Human Rights Instruments, supra note 70, at 53. See also note 234 supra.

337. U.N. Doc. A/CONF.9/C.1/SR.3, at 4 (1961) (remark of the Swiss Delegate)

338. U.N. HUMAN Rights INSTRUMENTs, supra note 70, at 54 (Art. 1(1)).

339. Id. (Art. 1(2)).

340. Id. (Art. 1(3)). A comparable provision is found in a Recommendation adopted by the Consultative Assembly of the Council of Europe:

The Assembly ...

Recommends that the Committee of Ministers:

1. Invite the Member Governments concerned to take the necessary measures so that legitimate children born in their territory of a marriage between a stateless father and a mother who is a national of their country automatically acquire by right the latter's nationality;

2. Suggest that these Governments draft the legal provisions which will be adopted on this matter in such a manner that the said children, if born in a territory other than that of the mother, do not acquire dual nationality nor become stateless; 3. Keep the Assembly informed of measures which may be taken to this end by the Governments concerned.

Consultative Assembly of the Council of Europe, Recommendation 194 of April 23, 1959.

341. U.N. Human Rights Instruments, supra note 70, at 54 (Art. 2).

342. The second paragraph of article 14 of the Hague Convention on Nationality reads:

A foundling is, until the contrary is proved, presumed to have been born on the territory of the State in which it was found.

179 L.N.T.S. 107. 
tive of the location, within territorial space or otherwise, of the ship or the aircraft at the time of birth. ${ }^{343}$ Subject to certain conditions, a contracting state must confer its nationality on a person, not born in its territory, who would otherwise be stateless, if at the time of his birth one of his parents possessed the nationality of that state. ${ }^{344}$

\section{(b). Statelessness Subsequent to Birth}

The parallel policy with respect to statelessness subsequent to birth has been stated, with equal brevity, by Hudson:

Loss of nationality subsequent to birth shall be conditional on the acquisition of another nationality. ${ }^{345}$

The movement toward this policy in general community perspectives is made explicit in prescriptions about the consequences of voluntary renunciation of nationality. Article 7 of the Hague Convention provides that an expatriation permit issued by a state "shall not entail loss of the nationality of the State which issues it, unless the person to whom it is issued possesses another nationality or unless and until he acquires another nationality." "An expatriation permit shall lapse if the holder does not acquire a new nationality" within the prescribed period, unless he "already possesses a nationality other than that of the State" issuing the permit. ${ }^{346}$ Similarly, the Convention on the Reduction of Statelessness provides:

If the law of a Contracting State entails loss of [sic] renunciation of nationality, such renunciation shall not result in loss of nationality unless the person concerned possesses or acquires another nationality. ${ }^{347}$

Of course, the otherwise commendable policy of minimizing statelessness, embodied in these provisions, might sometimes operate to tie an individual, against his will, to a political community with which he has lost all sense of identification and loyalty and from which he expects no genuine protection. For this reason the Convention on the Reduction of Statelessness provides that enforcement of the policy of preventing statelessness should not interfere with the freedom of move-

343. U.N. HUMAN Righrs INSTRUMENTS, supra note 70, at 54 (Art. 3).

344. Id. (Art. 4).

345. Hudson, supra note 1 , at 20 .

346. 179 L.N.T.S. 89, 101 .

347. U.N. HuMAN Rights Instruments, supra note 70, at 55 (Art. 7(l)(a)). 
ment, including ingress and egress, and with the right of asylum protected by the Universal Declaration of Human Rights. ${ }^{348}$

One intriguing question is whether an individual should be allowed to become stateless, if he so chooses, in defiance of the ordinarily benign policy of minimizing statelessness. In keeping with the overriding policy of honoring freedom of choice, there would appear no reason why an individual should not be allowed to render himself stateless, if the decision is freely made, with full appreciation of the resultant consequences.

Of more fundamental importance, however, for the realization of the policies of voluntary expatriation and minimization of statelessness, is the liberalization of states' requirements for conferring nationality subsequent to birth. This is an area for improvement, as neglected as it is important.

Although naturalization has long been perceived as the key to reduction of existing statelessness, ${ }^{349}$ states are notoriously reluctant to undertake the necessary humanitarian measures. At the 1930 Hague Conference for the Codification of International Law, the subject was barely considered, not because it was regarded as unimportant but because it raised serious problems arising from conflicts of nationality laws. ${ }^{350}$ Following the 1930 Hague Conference, international efforts were directed toward improving the status and treatment of refugees (de jure and de facto stateless persons) rather than toward enabling stateless persons to acquire some nationality. ${ }^{351}$

Community interest in improving naturalization laws was renewed in connection with the Universal Declaration of Human Rights of 1948. To give meaning to "the right to a nationality" proclaimed in the Universal Declaration, both the Secretary-General of the United Nations $^{352}$ and the Economic and Social Council ${ }^{353}$ urged governments to facilitate acquisition of nationality by stateless persons through their respective naturalization procedures. Some states have shown reluctance to discuss reforms which they regard as related to present, as contrasted with future, statelessness on the ground that naturalization

348. Id. (Art. 7(1)(b)).

349. See pp. 925-28 supra; A. Mutharika, supra note 294, at 92-100.

350 . This is evidenced by the official title of the Convention on Nationality adopted at the Conference, i.e., Convention on Certain Questions relating to the Conflict of Nationality Laws, 179 L.N.T.S. 89.

351. See pp. 976-78 infra.

352. A STUdY OF STATELESSNESS, supra note 149 , at 171 .

353. In its resolution 319B III of 16 August 1950, the Economic and Social Council invited "States to examine sympathetically applications for naturalization submitted by stateless persons habitually resident in their territory." 11 U.N. ECOSOC 3, Supp. 1, at 59, U.N. Doc. E/1849 (1950). 
is too "political" a matter. ${ }^{354}$ Thus, the International Law Commission had initially instructed its Special Rapporteur on "nationality, including statelessness," Roberto Cordova, to address himself only to future statelessness, not present statelessness. He soon discovered that it was impossible to focus on one to the exclusion of the other. ${ }^{355}$ Although he persuaded the International Law Commission to let him proceed by giving equal attention to both aspects of the problem, his proposals for reducing statelessness through naturalization were given little attention and support. ${ }^{356}$ As a consequence, the Convention on the Reduction of Statelessness, adopted in $1961,{ }^{357}$ is concerned primarily with the question of future statelessness. Its limited concern for the reduction of statelessness through naturalization is expressed in article 4, according to which a contracting state may grant its nationality, upon application in compliance with certain prescribed conditions, to a person not born in its territory "who would otherwise be stateless, if the nationality of one of his parents at the time of the person's birth was that of that State."

In this connection, a significant step is taken by article 32 of the Convention Relating to the Status of Stateless Persons of 1954, which provides:

The Contracting State shall as far as possible facilitate the assimilation and naturalization of stateless persons. They shall in particular make every effort to expedite naturalization proceedings and to reduce as far as possible the charges and costs of such proceedings. ${ }^{358}$

A comparable provision is found in article 34 of the Convention Relating to the Status of Refugees. ${ }^{359}$ Since both Conventions are widely accepted and have been in operation for some time, it is possible that more states will undertake serious efforts in this direction.

The general policy of making loss of one nationality contingent upon acquisition of another applies to various situations in which withdrawal of nationality is based on the individual's real or construc-

354. See Cordova, supra note 281 , at 27-28.

355. These words "future" and "present" obviously have no reference to modalities by which people become stateless. Measures such as liberalizing naturalization laws, which states refuse to consider because they could be related to existing stateless persons, may of course be of the utmost importance for alleviating future statelessness arising from the whole range of modalities by which people are made stateless.

356. Report of the International Law Commission Covering the Work of Its Sixth Session, supra note 319 , at 147.

357. U.N. Human Rights InSTRUMents, supra note 70, at 53.

358. 360 U.N.T.S. 117; U.N. HUMAN Rights INSTRUMENTs, supra note 70 , at 61 .

359. 189 U.N.T.S. 137; U.N. HUMAN Rights INSTRUMENTS, stipra note 70, at 63, 68. 
tive consent, that is, consent inferred from such acts as deliberate acquisition of the nationality of another state, taking of an oath of allegiance to another state, protracted residence abroad, marriage to an alien man, naturalization of parents by another government, legitimation, and adoption. ${ }^{360}$

Thus, the Convention on the Reduction of Statelessness provides that a national seeking "naturalization in a foreign country shall not lose his nationality unless he acquires or has been accorded assurance of acquiring the nationality of that foreign country." 361 With certain limited exceptions, a national shall not be made stateless because of "departure, residence abroad, failure to register or on any similar ground." ${ }^{62}$ The stated exceptions are meant to be exclusive. Thus, article $7(6)$ of the Convention states emphatically:

Except in the circumstances mentioned in this article, a person shall not lose the nationality of a Contracting State, if such loss would render him stateless, notwithstanding that such loss is not expressly prohibited by any other provision of this Convention..$^{363}$

The effect of marriage on the nationality of women, as noted, has been a matter of continuing interest. ${ }^{364}$ As a manifestation of the policy of minimizing statelessness, the trend has been away from the woman's automatic loss of her nationality upon marriage to an alien. ${ }^{365}$ Thus, the Hague Convention makes the loss of nationality of a woman married to a foreign national, by virtue either of the marriage or of her husband's change of nationality during marriage, conditional on "her acquiring the nationality of the husband." 368 Similarly, under the Convention on the Reduction of Statelessness, the loss of a woman's nationality because of marriage or her husband's loss of nationality is "conditional upon [her] possession or acquisition of another nationality." 367

These prescriptions, though protective, are less than adequate, especially from the perspective of equality of men and women. Thus, a critical focus in the ongoing world-wide movement for women's liberation has been equality of the sexes in the context of nationality; the principle of equality is perceived to be the fundamental, positive

360. See pp. 936.41 supra.

361. U.N. HUMAN Rights INSTRUMENTs, supra note 70, at 55 (Art. 7(2)).

362. Id. (Art. 7(3)).

363. Id. (Art. 7(6)).

364. See pp. $922-23,939-40$ supra.

365. See p. 940 supra.

366. 179 L.N.T.S. 89, 101 (Art. 8).

367. U.N. Human RIGhts INSTRUMENTs, supra note 70, at 55 (Art. 6). 
answer to the question of the statelessness of married women. ${ }^{368}$ This policy first found concrete expression in the international arena in 1933, when the Montevideo Convention on the Nationality of Women declared that "no distinction" shall be "based on sex as regards nationality" 369 and the Montevideo Convention on Nationality of the same date further provides that "neither matrimony nor its dissolution affects the nationality of the husband or wife."370

More recently, the policy has been crystallized by the adoption and application of the Convention on the Nationality of Married Women of $1957,{ }^{371}$ which proclaims that

neither the celebration nor the dissolution of a marriage between one of its nationals and an alien, nor the change of nationality by the husband during marriage, shall automatically affect the nationality of the wife $e^{372}$

and that

neither the voluntary acquisition of the nationality of another State nor the renunciation of its nationality by one of its nationals shall prevent the retention of its nationality by the wife of such national. ${ }^{373}$

The United Nations Declaration on Elimination of Discrimination Against Women of $1967^{374}$ reaffirms this policy in these words:

Women shall have the same rights as men to acquire, change or retain their nationality. Marriage to an alien shall not automatically affect the nationality of the wife either by rendering her stateless or by forcing upon her the nationality of her husband. ${ }^{375}$

The naturalization of parents, as mentioned above, ordinarily extends its effect to minor children. ${ }^{376}$ "In cases where minor children do not acquire the nationality of their parents as the result of the naturalization of the latter," the Hague Convention provides, "they shall retain their existing nationality." ${ }^{377}$ A similar protection is of-

368. See, e.g., Nationality of Married Women, supra note 66, at 6-7, 14-18.

369. 49 Stat. 2957, 2960; T.S. No. 875 (effective Aug. 29, 1934).

370. Nationality of Miarried Women, supra note 66, at 24 (Art. 6).

371. 309 U.N.T.S. 65; U.N. HUMAN Rights INSTRUMENTs, supra note 70, at 52.

372. U.N. Human Rights Instruments, supra note 70, at 52 (Art. 1).

373. Id. (Art. 2).

374. The Declaration, prepared by the Commission on Status of Women and the

Third Committee of the General Assembly, was adopted unanimously by the United

Nations General Assembly on November 7, 1967. G.A. Res. 2263, 22 GAOR Supp. 16, at

35, U.N. Doc. A/6716 (1967). For the text see Basic Documents on Human Righrs 183

(I. Brownlie ed. 1971).

375. Basic Documents on Human Rights, supra note 374, at 183, 185.

376. See pp. $924,940-41$ supra.

377. 179 L.N.T.S. 89, 103 (Art. 13). 
fered by the Hague Convention in connection with legitimation of an illegitimate child and with adoption. ${ }^{378}$ Moving beyond these provisions, the Convention on Reduction of Statelessness has formulated an all-inclusive protection clause, seeking to embrace all cases of change of personal status and to remove change of status as a cause of statelessness. Article 5(1) of the Convention states:

If the law of a Contracting State entails loss of nationality as a consequence of any change in the personal status of a person such as marriage, termination of marriage, legitimation, recognition or adoption, such loss shall be conditional upon possession or acquisition of another nationality. ${ }^{379}$

The growing general community condemnation of discriminatory and punitive denationalizations ${ }^{380}$ would appear to be establishing a comparable policy of minimizing statelessness in connection with such denationalizations. Article 8(1) of the Convention on the Reduction of Statelessness broadly pronounces that a "Contracting State shall not deprive a person of its nationality if such deprivation would render him stateless." 381 From this broad policy, unfortunately, some derogations-for acts "prejudicial to the vital interests of the State"are permitted. ${ }^{382}$ In light of the interpretations presently being given to the community prohibition of "cruel and inhuman punishment and treatment," ${ }^{383}$ these derogations could come to be regarded as impermissible.

Acquiring states have historically mitigated statelessness arising from territorial changes by conferring their nationality upon the inhabitants of the transferred territory or by giving such inhabitants the option of retaining their original nationality or accepting that of the acquiring state. ${ }^{384}$ Some protection from statelessness in this context is now specifically afforded by article 10 of the Convention on the Reduction of Statelessness:

1. Every treaty between Contracting States providing for the transfer of territory shall include provisions designed to secure that no person shall become stateless as a result of the transfer. A Contracting State shall use its best endeavours to secure that any such treaty made by it with a State which is not a party to this Convention includes such provisions.

378. Id. at 105 (Arts. 16-17).

379. U.N. HUMAN RIGHTS INSTRUMENTS, supra note 70, at 55.

380. See pp. $941-59$ supra.

381. U.N. HuMAN RIGHTS INSTRUMENTS, supra note 70, at 55.

382. Id. (Art. 8(3)).

383. See pp. 958-59 supra.

384. See A STUdY on STATEI.ESSNESs, supra note 149, at 150-53; Hudson, supra note 1 , at 19 . 
2. In the absence of such provisions the Contracting State to which territory is transferred or which otherwise acquires territory shall confer its nationality on such persons as would otherwise become stateless as a result of the transfer or acquisition. ${ }^{385}$

A policy of utmost voluntarism would of course afford the inhabitants the right of option as well. Unfortunately, such a proposal, though submitted by the International Law Commission, was not incorporated into the Convention. ${ }^{386}$

\section{Mitigations of Statelessness}

Turning from efforts to avoid or reduce statelessness to those designed to mitigate or improve the treatment of stateless persons, we call attention to the fact that this subject is commonly considered in conjunction with the treatment of refugees. ${ }^{387}$ Viewed strictly from the perspective of legal technicality, the concept of statelessness (having no nationality) and the concept of being a refugee (fleeing one's country in fear) are different. ${ }^{388}$ Just as stateless persons may or may not be refugees, so refugees may or may not be stateless persons. In terms of lack of governmental protection, refugees who nominally have a nationality may, however, be in no better position than stateless persons. Those refugees who legally have a nationality but in fact do not enjoy the protection of the government of their country of nationality are usually called de facto stateless refugees, to distinguish them from de jure stateless refugees. ${ }^{389}$ The majority of today's refugees are de facto rather than de jure stateless. Such refugees and stateless persons thus share one fate-they are "unprotected persons." 390 This close, though not entirely identical, relationship between stateless persons and refugees is vividly illustrated by the substantially identical provisions of two parallel conventions: the Convention Relating to the Status of Stateless Persons ${ }^{301}$ and the Convention Relating to the Status of Refugees. ${ }^{392}$

The first contemporary international effort to protect and assist

385. U.N. HuMAN Rights INSTRUMENTs, supra note 70, at 56 .

386. Weis, supra note 122 , at 1084 .

387. See, e.g., Weis, The Convention Relating to the Status of Stateless Persons, 10 INT'L \& COMP. L.Q. 255 (1961); A STUdY OF STATEL.ESSNESS, supra note 149; authoritics cited in note 15 supra.

388. See 1 A. Grahl-Madsen, The Status of Refugees in International Law 73-78 (1966); A Study of Statelessness, supra note 149, at 9-10; Van Heuven Goldhart, The Problem of Refugees, 82 Hacue RecueIL 265, 267-71 (1953).

389. A StUdy OF Statel.ESSNESS, supra note 149, at 8-9.

390. P. WeIs, supra note 1 , at 168 .

391. 360 U.N.T.S. 117; U.N. HuMAN Rights Instruments, supra note 70, at 57.

392. 189 U.N.T.S. 137; U.N. HUMAN RIGHTS INSTRUMENTs, supra note 70, at 63. 
stateless persons and refugees commenced in 1921 when the League of Nations created the Office of High Commissioner for Russian Refugees, responding to the critical needs of those refugees rendered stateless, as may be recalled, by the mass denationalization measures undertaken in Russia in the wake of the revolution. ${ }^{393}$ This was followed by the conclusion of the Convention Relating to the International Status of Refugees ${ }^{394}$ in 1933 and the establishment of the Office of the League of Nations High Commissioner for Refugees in 1938.395 Since World War II, the need to protect and assist stateless persons and refugees has grown. ${ }^{306}$ Under the auspices of the United Nations, the Office of the United Nations High Commissioner for Refugees (UNHCR) was created in $1950 .^{397}$ Shortly thereafter the Convention Relating to the Status of Refugees of July 28, 1951, and the Convention Relating to the Status of Stateless Persons of September 24, 1954, successively came into existence. The scope of the 1951 Refugees Convention was greatly expanded by the adoption of the Protocol Relating to the Status of Refugees in $1967 .^{398}$

The Convention Relating to the Status of Stateless Persons, together with the Convention Relating to the Status of Refugees (frequently called the Magna Carta of Refugees), appear to afford comprehensive protection for stateless persons and refugees. The need for a separate Convention Relating to the Status of Stateless Persons was dictated by the consideration, in the words of its preamble, that "only those stateless persons who are also refugees are covered by the Convention Re-

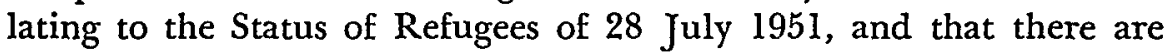
many stateless persons who are not covered by that Convention."'399 A major difference between the two conventions relates to the role of

393. See pp. 944-45 supra.

394. Signed at Geneva on October 28, 1933, the Convention defined the legal status of those refugees covered by the Convention, i.e., Russian, Armenian, and assimilated refugees. 159 L.N.T.S. 199, 201.

395. For this and subsequent developments, see Van Heuven Goldhart, supra note 388 , at $271-75$.

396. See generally L. Holborn, supra note 15; J. Veranant, supra note 15.

397. The Statute of the Office of the United Nations High Commissioner for Refugees was adopted by the U.N. General Assembly in its resolution 428 (V) of 14 December 1950. U.N. HUMAN RIGHTS INSTRUMENTs, supra note 70, at 72. For the work of the United Nations High Commissioner for Refugees, see A Mandate to Protect AND Assist Refugess, supra note 15; Report of the United Nations High Commissioner for Refugees, supra note 233; Weis, The Office of the United Nations High Commissioner for Refugees and Human Rights, l HuMAN RIGHTs J. 243 (1968).

398. 606 U.N.T.S. 267; U.N. HUMAN Rights Instruments, supra note 70, at 70 . See note 237 supra. The purpose of the Protocol is to expand international protection for refugees by removing the temporal and geographical restrictions inherent in article 1 of the 1951 Convention Relating to the Status of Refugees. The substantive provisions (articles 2 to 34 inclusive) of the 1951 Convention are made part of the Protocol in art. 1(1).

399. 360 U.N.T.S. 117, 130; U.N. HUMAN Rights INSTRUMENTs, supra note 70, at 57. 
UNHCR: While article 35 of the Refugees Convention explicitly entrusts to the Office of the High Commissioner the task of coordinating with the contracting states and supervising the application of the Convention, ${ }^{400}$ there is no comparable provision in the other Convention. Otherwise, in terms of substantive protection and actual wording, the Convention Relating to the Status of Stateless Persons is essentially patterned after the Convention Relating to the Status of Refugees. Hence, an examination of treatment of stateless persons also reveals the treatment being accorded to refugees.

Under the Convention Relating to the Status of Stateless Persons, the treatment afforded for stateless persons is divided in convention terms into five broad and overlapping categories:

(I) General protection: undelimited provisions for protection without specifying "national treatment," "alien treatment" and so on; ${ }^{401}$

(II) National treatment: "treatment at least as favorable as that accorded to their nationals"; 402

(III) Favorable alien treatment: "treatment as favorable as possible, and in any event, not less favorable than that accorded to aliens generally in the same circumstances"; 403

(IV) Treatment accorded to nationals of the country of habitual residence: "the treatment granted to a national of the country of his habitual residence," 404 "the same protection as is accorded to nationals" of the country of "habitual residence"; 405

(V) Alien treatment: "the same treatment as is accorded to aliens generally," 406 "subject to regulations applicable to aliens generally in the same circumstances." 407

The following chart may indicate the kind and scope of treatment specified in different value processes:

400. Article 35 of the Refugee Convention reads:

1. The Contracting States undertake to co-operate with the Office of the United Nations High Commissioner for Refugees, or any other agency of the United $\mathrm{Na}$ tions which may succeed it, in the exercise of its functions, and shall in particular facilitate its duty of supervising the application of the provisions of this Convention.

2. In order to enable the Office of the High Commissioner or any other agency of the United Nations which may succeed it, to make reports to the competent organs of the United Nations, the Contracting States undertake to provide them in the appropriate form with information and statistical data requested concerning:

(a) The condition of refugees,

(b) The implementation of this Convention, and

(c) Laws, regulations and decrees which are, or may hereafter be, in force re. lating to refugees.

U.N. HuMAN RIGHTS INSTRUMENTS, supra note 70, at 68 .

401. Id. at 58-61 (Arts. 3, 5, 12, 16(1), 25, 27, 28, 30, 31, and 32).

402. Id. at 58-60 (Arts. 4, 14, 16(2), 20, 22(1), 23, and 24).

403. Id. at 59.60 (Arts. 13, 15, 17, 18, 19,21, and 22(2))

404. Id. at 59 (Art. 16(3)).

405. Id. (Art. 14).

406. Id. at 58 (Art. 7(1)).

407. Id. at 61 (Art. 26). 
Nationality and Human Rights

CATEGORY OF TREATMENT

\begin{tabular}{|c|c|c|c|c|c|}
\hline $\begin{array}{c}\text { VALUE } \\
\text { CATEGORY }\end{array}$ & $\begin{array}{l}\text { I. General } \\
\text { Protection }\end{array}$ & $\begin{array}{l}\text { II. National } \\
\text { Treatment }\end{array}$ & $\begin{array}{c}\text { III. Favorable } \\
\text { Alien } \\
\text { Treatment }\end{array}$ & $\begin{array}{l}\text { IV. Treatment } \\
\text { Accorded to } \\
\text { Nationals of } \\
\text { the Country } \\
\text { of Habitual } \\
\text { Residence }\end{array}$ & $\begin{array}{l}\text { V. Alien } \\
\text { Treatment }\end{array}$ \\
\hline \multirow[t]{7}{*}{ Power } & $\begin{array}{l}\text { rights granted } \\
\text { apart from the } \\
\text { Convention } \\
\text { (art. 5) }\end{array}$ & & & & $\begin{array}{l}\text { general pro- } \\
\text { vision (art. } \\
7(1) \text { ) } \\
\text { freedom of } \\
\text { movement } \\
\text { (art. 26) }\end{array}$ \\
\hline & $\begin{array}{l}\text { access to } \\
\text { courts (art. } 16 \\
\text { (1)) }\end{array}$ & $\begin{array}{l}\text { access to } \\
\text { courts (art. } \\
16(2))\end{array}$ & & $\begin{array}{l}\text { access to } \\
\text { courts (art. } \\
16(3))\end{array}$ & \\
\hline & $\begin{array}{l}\text { administrative } \\
\text { assistance } \\
\text { (art. 25) }\end{array}$ & & & & \\
\hline & $\begin{array}{l}\text { identity } \\
\text { papers (art. 27) }\end{array}$ & & & & \\
\hline & $\begin{array}{l}\text { travel docu- } \\
\text { ments (art. 28) }\end{array}$ & & & & \\
\hline & $\begin{array}{l}\text { nonexpulsion } \\
\text { (art. 31) }\end{array}$ & & & & \\
\hline & $\begin{array}{l}\text { naturalization } \\
\text { (art. 32) }\end{array}$ & & & & \\
\hline Respect & $\begin{array}{l}\text { nondiscrimi- } \\
\text { nation (art. 3) }\end{array}$ & & $\begin{array}{l}\text { right of non- } \\
\text { political associ- } \\
\text { ation (art. 15) }\end{array}$ & & \\
\hline $\begin{array}{l}\text { Enlighten- } \\
\text { ment }\end{array}$ & & $\begin{array}{l}\text { elementary } \\
\text { education (art. } \\
22(1) \text { ) }\end{array}$ & $\begin{array}{l}\text { non-elemen- } \\
\text { tary education } \\
\text { (art. 22(2)) }\end{array}$ & & \\
\hline Well-Being & & $\begin{array}{l}\text { rationing (art. } \\
20)\end{array}$ & $\begin{array}{l}\text { housing (art. } \\
\text { 21) }\end{array}$ & & \\
\hline \multirow[t]{3}{*}{ Wealth } & $\begin{array}{l}\text { transfer of } \\
\text { assets (art. 30) }\end{array}$ & $\begin{array}{l}\text { artistic rights } \\
\text { and industrial } \\
\text { property (art. } \\
\text { 14) }\end{array}$ & $\begin{array}{l}\text { movable and } \\
\text { immovable } \\
\text { property (art. } \\
\text { 13) }\end{array}$ & $\begin{array}{l}\text { artistic rights } \\
\text { and industrial } \\
\text { property (art. } \\
\text { 14) }\end{array}$ & \\
\hline & & $\begin{array}{l}\text { public relief } \\
\text { (art. 23) }\end{array}$ & $\begin{array}{l}\text { wage-earning } \\
\text { employment } \\
\text { (art. 17) }\end{array}$ & & \\
\hline & & $\begin{array}{l}\text { labor legisla- } \\
\text { tion and so- } \\
\text { cial security } \\
\text { (art. 24) }\end{array}$ & $\begin{array}{l}\text { self-employ- } \\
\text { ment (art. 18) }\end{array}$ & & \\
\hline Skill & & & $\begin{array}{l}\text { liberal profes- } \\
\text { sions (art. 19) }\end{array}$ & & \\
\hline Affection & $\begin{array}{l}\text { personal status } \\
\text { (art. 12) }\end{array}$ & & & & \\
\hline Rectitude & & $\begin{array}{l}\text { religion (art. } \\
\text { 4) }\end{array}$ & & & \\
\hline
\end{tabular}


This chart demonstrates that stateless persons are accorded substantial protection even in power processes. ${ }^{408}$ Of special importance are provisions for access to courts, ${ }^{409}$ administrative assistance, ${ }^{410}$ identity papers, ${ }^{411}$ travel documents, ${ }^{412}$ and nonexpulsion. ${ }^{413}$ If, however,

408. But see A. Mutharika, supra note 294, at 159-61.

409. Article 16 of the Convention Relating to the Status of Stateless Persons reads:

1. A stateless person shall have free access to the Courts of Law on the territory of all Contracting States.

2. A stateless person shall enjoy in the Contracting State in which he has his habitual residence the same treatment as a national in matters pertaining to access to the Courts, including legal assistance and exemption from cautio judicatum solvi.

3. A stateless person shall be accorded in the matters referred to in paragraph 2 in countries other than that in which he has his habitual residence the treatment granted to a national of the country of his habitual residence.

U.N. HuMAN Rights INSTRUMENTS, supra note 70, at 59 .

410. Article 25 of the Convention states:

1. When the exercise of a right by a stateless person would normally require the assistance of authorities of a foreign country to whom he cannot have recourse, the Contracting State in whose territory he is residing shall arrange that such assistance be afforded to him by their own authorities.

2. The authority or authorities mentioned in paragraph 1 shall deliver or cause to be delivered under their supervision to stateless persons such documents or certifications as would normally be delivered to aliens by or through their national authorities.

3. Documents or certifications so delivered shall stand in the stead of the official instruments delivered to aliens by or through their national authorities and shall be given credence in the absence of proof to the contrary.

4. Subject to such exceptional treatments as may be granted to indigent persons, fees may be charged for the services mentioned herein, but such fees shall be moderate and commensurate with those charged to nationals for similar services.

5. The provisions of this article shall be without prejudice to articles 27 and 28 .

Id. at 60-61.

411. Article 27 of the Convention reads:

The Contracting States shall issue identity papers to any stateless person in their territory who does not possess a valid travel document.

Id. at 61 .

412. Article 28 of the Convention provides:

The Contracting States shall isste to stateless persons lawfully staying in their territory travel documents for the purpose of travel outside their territory, unless compelling reasons of national security or pubiic order otherwise require, and the provisions of the Schedule to this Convention shall apply with respect to such documents. The Contracting States may issue such a travel document to any other stateless person in their territory; they shall in particular give sympathetic con. sideration to the issue of such a travel document to stateless persons in their territory who are unable to obtain a travel document from the country of their lawful residence.

Id.

413. Article 31 of the Convention reads:

1. The Contracting States shall not expel a stateless person lawfully in their territory save on grounds of national security or public order.

2. The expulsion of such a stateless person shall be only in pursuance of a decision reached in accordance with due process of law. Except where compelling reasons of national security otherwise require, the stateless person shall be allowed to submit evidence to clear himself, and to appeal to and be represented for the purpose before competent authority or a person or persons specially designated by the competent authority.

3. The Contracting States shall allow such a stateless person a reasonable period within which to seek legal admission into another country. The Contracting States reserve the right to apply during that period such internal measures as they may deem necessary.

Id. In this regard, the Convention Relating to the Status of Refugees affords more 
they were given full participation in the power process-with all the attendant rights and responsibilities in voting and office-holdingthey would in effect be full-fledged nationals. Hence, naturalization would appear, as emphasized above and by this Convention, ${ }^{\mathbf{4 1 4}}$ to remain an important remedy for powerlessness.

All of these protections uniquely tailored for stateless persons do not preclude them from claiming the benefit of other prescriptions for protecting the rights of all human beings.15 What is most needed for the protection of stateless and other human beings is wider acceptance and application of all of the many prescriptions already designed for such protection. . $^{416}$

\section{E. Claims Relating to Multiple Nationality}

The principal thrust of inherited international law relating to multiple nationality has been toward the protection of state interests rather than the protection of individual human rights. Multiple nationality differs from statelessness in that it may confer some benefits upon individuals. Thus it may provide multiple protectors in the external arena ${ }^{417}$ or afford physical access to more than one country, with opportunities to participate in the internal value processes of all such countries.

Such benefits may, however, be accompanied, and even outweighed, by severe burdens and responsibilities. Thus, a person of multiple nationality may, like a stateless person, be deprived of all protectors in the external arena. Traditional doctrine holds that one state of nationality cannot protect an individual against another state of his nationality. ${ }^{418}$ If the party imposing deprivations happens to be a state

comprehensive protection in its article 31 (refugees unlawfully in the country of refuge), article 32 (expulsion), and article 33 (prohibition of expulsion or return ("refoulement")). Id. at 68 .

414. Article 32 of the Convention provides:

The Contracting States shall as far as possible facilitate the assimilation and naturalization of stateless persons. They shall in particular make every effort to expedite naturalization proceedings and to reduce as far as possible the charges and costs of such proceedings.

Id. at 61 .

415. For compilations of human rights prescriptions, see U.N. Human Rights INstruments, supra note 70; Basic Documents on Human Rights, supra note 374.

416. It is especially important that wider acceptance be accorded to the Convention on the Reduction of Statelessness so that it can soon go into effect and command wide application.

417. Vis-it-vis a third state, a person having multiple nationality enjoys multiple protectors:

But against third States each of them appears as his [dual national's] sovereign, and it is therefore possible that each of them can exercise its right of protection over him within third States.

1 Oppenheim-Lauterpacht, supra note 76, at 666.

118. See p. 987 infra. 
of his nationality, the individual having multiple nationality may never get a hearing on the merits of his claim.

A multiple national may in fact be exposed to deprivations inimical to human rights throughout all the different value processes. ${ }^{410}$ He may be subjected to the civil and criminal jurisdiction, which follows a national wherever he goes, of two or more states; he may be subject to the laws relating to treason, ${ }^{420}$ enemy status, military service and security clearance of more than one state. More than one state may have jurisdiction to tax him, to expropriate his property, to impose restrictions on his trading activities, and to restrict disposition of his property. More than one state may discriminate against him; he may be discriminated against on different grounds in different communities. He may be subjected to physical and psychological insecurity in more than one state. He may be subjected to compulsory education in more than one state. More than one state may seek to impose restrictions on his practice of certain professions. More than one state may assert jurisdiction with respect to his family life, including marriage, children's up-bringing, education and welfare. Finally, more than one state may seek to restrict his religious affiliations and activities.

The causes of multiple nationality, as of statelessness, are to be found in the wide diversity of state laws about the conferment and withdrawal of nationality. "The most frequent case of double nationality at birth," observed Hudson, "is caused by the application of jus soli and jus sanguinis to the same individual: a person born in a country which has the jus soli, of parents who have the nationality of a country which employs jus sanguinis, becomes a double national or sujet mixte." +21 The same result may follow when states employ varying combinations of $j u s$ soli and $j u s$ sanguinis. Multiple nationality

419. As declared in Inouye Kanao v. The King,

if a person possesses dual nationality ... it does not mean that he owes any the less allegiance to this country than a person who is only a British subject. Dual nationality is not half one nationality and half another but two complete nationalities so far as our law is concerned ....

[1947] Ann. Dig. 103, 106 (No. 39) (Appellate Jurisdiction, Hong Kong).

420. As Bar-Yaacov puts it, "The legal status of an individual who happens to possess the nationalities of two belligerent States carries with it serious disadvantages. If both States require of such an individual the fulfilment of the duties of allegiance, he is likely to commit the criminal offence of treason with regard to one of them." Hc "may be compelled to fight against one of the belligerents; or may voluntarily adopt the cause of one country and commit acts which are treasonable as regards the other country; or he may assist one of the parties without committing acts amounting to treason against the other party." N. BAR-YAacov, Dual NATIONALITY 54, 57 (1961). See also Orfield, The Legal Effects of Dual Nationality, 17 Gro. Wash. L. Rev. 427, 429 (1949); Vilkov, The Settlement of Problems of Dual Nationality under International Law, 1959 SOVIET Y.B. INT'L L. 371 (1960).

421. Hudson, supra note 1 , at 10 . 
will also occur when an individual acquires subsequent to birth another nationality-by virtue of application, certain events (e.g., marriage, naturalization of parents, legitimation, adoption), or territorial changes-without losing his original nationality. ${ }^{422}$

International efforts to regulate multiple nationality have, again as with statelessness, been twofold: to minimize the occurrence of multiple nationality and to ameliorate the deprivations imposed upon people of multiple nationality. The Inter-American Convention on the Status of Naturalized Citizens concluded at Rio de Janeiro in 1906 dealt with naturalized persons returning to the state of their original nationality. ${ }^{423}$ Under the terms of the Convention, a naturalized person taking up "residence in his native country without the intention of returning to the country in which he has been naturalized ... will be considered as having reassumed his original citizenship, and as having renounced the citizenship acquired by the said naturalization." 424 Unless proved to the contrary, further, "the intention not to return will be presumed to exist when the naturalized person shall have resided in his native country for more than two years." 425 In their respective peace treaties with the Allied Powers after World War I, Germany, Austria, and Hungary undertook to recognize any new nationality acquired by their nationals pursuant to the laws of the Allied and Associated Powers, regarding "such persons as having in consequence of the acquisition of such new nationality, in all respects severed their allegiance to their country of origin." $\mathbf{4 2 6}$

Responding to the urgent problems of multiple nationality (and also statelessness) in the aftermath of World War I, the Hague Conference for the Codification of International Law of 1930 still represents the most important effort to deal with the problem of multiple nationality. Theoretically, multiple nationality at birth could be eliminated by an outright, universal adoption of a single principle for conferment. Such a potentially promising approach, however, was obviously unacceptable to various governments, for, in the words of the Dutch delegation,

422. See Survey of the Problem of Multiple Nationality Prepared by the Secretariat, [1954] 2 Y.B. INT'L L. Comm'N 52, 64-85, U.N. Doc. A/CN.4/84 (1954); N. BaR-YaAcov, supra note 420 , at $437-42$.

423. See R. Flournoy \& M. Hudson, supra note 1 , at 645 .

424. Id. Art. 1 .

425. Id. Art. 2.

426. Treaty of Versailles, June 28, 1919, art. 278, 2 Major Peace. Treaties of Modern History 1648-1967, at 1265, 1433 (F. Israel ed. 1967); Treaty of St. Germain, September 10, 1919, art. 230, 3 id. at 1535, 1647; Treaty of Trianon, June 4, 1920, art. 213, 3 id. at 1863,1971 . 
it would be easier to obtain unanimity for a rule which admitted situations in which an individual had no nationality or two nationalities and regulated the resulting conflicts, than to establish a formula which would result in restricting to some extent the State's power of legislation. ${ }^{427}$

Attention was, hence, centered merely on minimizing the number of cases of multiple nationality.

Though the desire for the minimization of "dual" nationality was unanimously expressed in the Final Act of the Conference, ${ }^{428}$ solutions to the question of multiple nationality, as finally adopted, were limited in scope. Article 6 of the Hague Convention states:

Without prejudice to the liberty of a State to accord wider rights to renounce its nationality, a person possessing two nationalities acquired without any voluntary act on his part may renounce one of them with the authorisation of the State whose nationality he desires to surrender.

The authorisation may not be refused in the case of a person who has his habitual and principal residence abroad, if the conditions laid down in the law of the State whose nationality he desires to surrender are satisfied. ${ }^{429}$

A special provision was made with respect to children born to persons enjoying diplomatic immunities. ${ }^{430}$

The proposal that a person having multiple nationality at birth be afforded a right of option failed to gain support. ${ }^{431}$ Instead the Conference recommended in its Final Act that

427. League of Nations, Conference for the Codification of International Law: Bases of Drscussion, League of Nations Publication Series 1929.V.1 (C.73. M.38. 1929.V.), at 11 [hereinafter cited as BASES OF Discussion].

428. Final Act of the Hague Conference, supra note 111, at 14.

429. 179 L.N.T.S. 89 , 101 .

430. Article 12 reads:

Rules of law which confer nationality by reason of birth on the territory of a State shall not apply automatically to children born to persons enjoying diplomatic immunities in the country where the birth occurs.

The law of each State shall permit children of consuls de carriere, or of officials of foreign States charged with official missions by their Governments, to becomc divested, by repudiation or otherwise, of the nationality of the State in which they were born, in any case in which on birth they acquired dual nationality, provided that they retain the nationality of their parents.

Id. at 103 .

431. The delegation of Finland proposed to "make it the duty" of the possessor of double nationality "to opt for one or other of the nationalities." Bases of Discussion, supra note 427 , at 83 . 
States should adopt legislation designed to facilitate, in the case of persons possessing two or more nationalities at birth, the renunciation of the nationality of the countries in which they are not resident, without subjecting such renunciation to unnecessary conditions . . .

\section{and that}

States should apply the principle that the acquisition of a foreign nationality through naturalisation involves the loss of the previous nationality. ${ }^{432}$

Recently, the Council of Europe adopted the Convention of Reduction of Cases of Multiple Nationality and Military Obligations in Cases of Multiple Nationality. ${ }^{433}$ Article 1 of this Convention reads in part:

1. Nationals of the Contracting Parties who are of full age and who acquire of their own free will, by means of naturalisation, option or recovery, the nationality of another Party shall lose their former nationality. They shall not be authorised to retain their former nationality.

2. Nationals of the Contracting Parties who are minors and acquire by the same means the nationality of another Party shall also lose their former nationality if, where their national law provides for the loss of nationality in such cases, they have been duly empowered or represented. They shall not be authorised to retain their former nationality. ${ }^{\$ 34}$

432. Final Act of the Hague Conference, supra note 111, at 14 .

433. Europ. T.S. No. 43 (1963).

434. Id. at 2. The remainder of this article reads as follows:

3. Minor children, other than those who are or have been married, shall likewise lose their former nationality in the event of the acquisition ipso jure of the nationality of another Contracting Party upon and by reason of the naturalisation or the exercise of an option or the recovery of nationality by their father and mother. Where only one parent loses his former nationality, the law of that Contracting Party whose nationality the minor possessed shall determine from which of his parents he shall derive his nationality. In the latter case, the said law may make the loss of his nationality subject to the prior consent of the other parent or the guardian of his acquiring the new nationality.

However, without prejudice to the provisions of the law of each of the Contracting Parties concerning the recovery of nationality, the Party of which the minor referred to in the foregoing paragraph possessed the nationality may lay down special conditions on which they may recover that nationality of their own free will after attaining their majority.

4. In so far as concerns the loss of nationality as provided for in the present Article, the age of majority and minority and the conditions of capacity and representation shall be determined by the law of the Contracting Party whose nationality the person concerned possesses.

Id. at 2-3. 
A person having "the nationality of two or more Contracting Parties may renounce one or more of these nationalities, with the consent of the Contracting Party whose nationality he desires to renounce." 435 To restrain the contracting state from arbitrarily withholding such consent, the Convention further provides:

Such consent may not be withheld by the Contracting Party whose nationality a person of full age possesses ipso jure, provided that the said person has, for the past ten years, had his ordinary residence outside the territory of that Party and also provided that he has his ordinary residence in the territory of the Party whose nationality he intends to retain.

Consent may likewise not be withheld by the Contracting Party in the case of minors who fulfil the conditions stipulated in the preceding paragraph, provided that their national law allows them to give up their nationality by means of a simple declaration and provided also that they have been duly empowered or represented. ${ }^{436}$

In addition to such multilateral treaties, ${ }^{437}$ a number of bilateral treaties have been concluded to minimize double nationality. Of special importance are a series of treaties, generally known as Bancroft treaties, concluded in 1868 and shortly thereafter between the United States and some of the European countries. ${ }^{438}$ These treaties either stipulate which of the nationalities possessed is to prevail as between the contracting states or seek to facilitate revision of pertinent nationality laws to avoid instances of double nationality.

In the late 1950's the Soviet Union concluded a series of bilateral treaties with its fraternal states regarding the matter of double nationality. ${ }^{439}$ According to these treaties, persons possessing the nationality of both contracting states and residing in the territory of one of them may opt for the single nationality of the other by filing a declaration to that effect with the latter state's embassy within one year from the effective date of the respective treaty. The declaration of option is subject to scrutiny by the competent officials to whom it has been communicated. The contracting states pledge to inform each other of the applications accepted, and, in some instances, rejected. Persons

435. Id. at 3 (Art. 2(1)).

436. Id. (Art. 2(2)).

437. See Survey of the Problem of Multiple Nationality Prepared by the Secretariat, supra note 422 , at $90-94$.

438. Id. at 91-92. See note I08 supra.

439. See Sipkov, Settlement of Dual Nationality in European Communist Countries, 56 AM. J. INT'L L. 1010 (1962). 
failing to exercise their right of option are regarded solely as nationals of the state of residence. ${ }^{440}$

The demand for further effort, as expressed at the Hague Conference, to solve the problem of multiple nationality has thus elicited little effective response. In connection with its work on "nationality including statelessness," the International Law Commission paid only scant attention to the matter of multiple nationality. ${ }^{441}$ In 1954 , after a general debate in which divergent views were aired, the Commission decided to defer further consideration of the topic, due partly to the lack of a sense of urgency and partly to the reluctance of governments to undertake effective measures of solution. ${ }^{442}$

The need for amelioration of the plight of individuals having multiple nationality is well illustrated by the decisions that deny such individuals protection by one state of their nationality against the acts of another state of their nationality. This restrictive doctrine was formulated in article 4 of the 1930 Hague Convention on Nationality in these words:

A State may not afford diplomatic protection to one of its nationals against a State whose nationality such person also possesses.443

The International Court of Justice, in the Reparation for Injuries Case, refers to this article as embodying an "ordinary practice whereby a State does not exercise protection on behalf of one of its nationals against a State which regards him as its own national . . ."444

When an individual claimant is alleged to be a national of both the claimant state and the respondent state, an international tribunal would ordinarily decline jurisdiction pursuant to article 4 of the Hague Convention. ${ }^{445}$ Recently, however, this restrictive doctrine has to a considerable degree been qualified, for the benefit of individuals, by the principle of effective (i.e., active, dominant) nationality. That is

440. See treaties concluded by the Soviet Union with, respectively, Yugoslavia, May 22, 1956, 259 U.N.T.S. 155; Hungary, Aug. 24, 1957, 318 U.N.T.S. 35; Romania, Sept. 4, 1957, 318 U.N.T.S. 89; Albania, Sept. 18, 1957, 307 U.N.T.S. 251; Czechoslovakia, Oct. 5, 1957, 320 U.N.T.S. 111; Bulgaria, Dec. 12, 1957, 302 U.N.T.S. 3; the Democratic Republic of Korea, Dec. 16, 1957, 292 U.N.T.S. 107; Poland, Jan. 21, 1958, 319 U.N.T.S. 277; and Mongolia, Aug. 25, 1958, 322 U.N.T.S. 201.

441. The Commission's Special Rapporteur had submitted a report, Report on Mul. tiple Nationality, supra note 316, and the U.N. Secretariat a memorandum, Survey of the Problem of Multiple Nationality Prepared by the Secretariat, supra note 422.

442. Report of the International Law Commission Covering the Work of Its Sixth Session, supra note 319 , at $148-49$.

443. 179 L.N.T.S. 89, 101 (Art. 4).

444. Advisory Opinion on Reparation for Injuries Suffered in the Service of the

United Nations, [1949] I.C.J. 173, 186.

445. 179 L.N.T.S. 89,101 . 
to say, if the claimant state is found to be the state of the individual's effective nationality, the claim will not be dismissed for lack of jurisdiction. On the other hand, if the respondent state is found to be the state of his effective nationality, the claim will be dismissed and article 4 applied in its pristine severity.

The substantive content of "effective nationality" is intimated in article 5 of the Hague Convention on Nationality in its specification of the criterion to be applied by a third state in a case of dual nationality. The article reads:

Within a third State, a person having more than one nationality shall be treated as if he had only one. Without prejudice to the application of its law in matters of personal status and of any conventions in force, a third State shall, of the nationalities which any such person possesses, recognise exclusively in its territory either the nationality of the country in which he is habitually and principally resident, or the nationality of the country with which in the circumstances he appears to be in fact most closely connected. 440

Considerably more detail is offered in the unfortunate Nottebohm case, ${ }^{447}$ in which, though multiple nationality was not involved, the International Court of Justice attempted to build upon the analogy of dual nationality and formulated the concept of effective nationality in words which bear repetition:

International arbitrators have decided in the same way numerous cases of dual nationality, where the question arose with regard to the exercise of protection. They have given their preference to the real and effective nationality, that which accorded with the facts, that based on stronger factual ties between the person concerned and one of the States whose nationality is involved. Different factors are taken into consideration, and their importance will vary from one case to the next: the habitual residence of the individual concerned is an important factor, but there are other factors such as the centre of his interests, his family ties, his participation in public life, attachment shown by him for a given country and inculcated in his children :...448

446. Id.

447. Nottebohm Case, [1955] I.C.J. 4.

448. Id. at 22. In regard to territory and resources, the doctrine of historical use has been well established. It would appear that a comparable doctrine could be developed to serve the acquisition of nationality. Individuals should be able to acquire nationality by effective participation in the social process. When individuals have lived in a territory for a long period of time, they become effective members of that particular community. They may in effect be more active community members, in the sense of participation in value processes, than many nominal nationals of that community. 
The most beneficient employment, from the perspective of human rights, of the concept of "effective nationality" has been in according an individual of multiple nationality a protector against deprivations by a state of his nationality. When the claimant state is proved to be the state of the claimant's effective nationality, this concept has been successfully invoked against another state of the claimant's nationality, thereby overcoming the non-protective restriction inherent in article 4 of the Hague Convention on Nationality and facilitating a hearing on merits of claims asserted by a multiple national claimant.

In the well-known Apostolidis $v$. The Turkish Government, ${ }^{449}$ Turkey challenged the jurisdiction of the Franco-Turkish Mixed Arbitral Tribunal on the ground that all the claimants had retained Turkish nationality under Turkish law, which denied the validity of the foreign naturalization of Turkish nationals without Turkish authorization. The claimants had been naturalized as French nationals in 1912. The Tribunal rejected the Turkish contention, noting that

all other judicial authorities, including the Mixed Arbitral Tribunal,-which, as regards public international law, is not bound by the municipal legislation of one of the contracting States-are bound to recognize the validity of the change of nationality and to recognize the claimants as French nationals. 450

This judgment has been properly construed to mean that "the Tribunal simply disregarded the Turkish nationality for the purposes of the claim, thus attributing to the French nationality of the claimant a predominant character in order to establish jurisdiction." 451

In the case of Barthez de Monfort v. Treuhander Hauptverwaltung $^{452}$ before the Franco-German Mixed Tribunal, the claimant possessed both French and German nationality, the latter of which she acquired through the naturalization of her husband in Germany; she had never abandoned her domicile in France. It was held that

the principle of active nationality, i.e., the determination of nationality by a combination of elements of fact and of law, must be followed by an international tribunal, and that the claimant was accordingly a French national and was entitled to judgment accordingly. 453

449. Franco-Turkish Mixed Arbitral Tribunal, 1928, 8 RecueIL DES Decisions Des Tribunaux ARbirraux Mixres 373 (1929), translated and abbreviated in H. BRIGGs, supra note 10 , at 513 .

450. Id. at 514 .

451. N. BAR-YAACOV, supra note 420 , at 215 .

452. [1925-1926] Ann. Dig. 279 (No. 206).

453. Id. 
In the Georges Pinson case, ${ }^{454}$ decided by the French-Mexican Mixed Claims Commission in 1928, France asserted a claim on behalf of an individual alleged to be a French national jure sanguinis and a Mexican national jure soli. The individual had ties to both countries and the laws of both countries had been construed to confer nationality. In response to the Mexican contention, based on article 4 of the Hague Convention on Nationality, the Commission held that

even if the case were recognised as one of double nationality from the strictly legal point of view, it would be very doubtful if the claimant could not have invoked the Convention notwithstanding, owing to the fact that the Mexican government itself had always considered him, officially and exclusively, as a French subject. ${ }^{450}$

The concept of effective nationality is, unhappily, sometimes employed to deny the individual a protector on the merits when the defendant state is found to be the state of stronger ties. Thus, the Canevaro case, ${ }^{400}$ brought in 1912 by Italy against Peru before the Permanent Court of Arbitration and often cited as a leading case defining the concept of effective nationality, ${ }^{457}$ involved three brothers, two of whom were Italian nationals; the third, Rafael Canevaro, possessed Peruvian nationality jure soli and Italian nationality jure sanguinis. In response to the Peruvian contention that Rafael Canevaro could not be considered an Italian claimant, the tribunal noted that he had on several occasions acted as a Peruvian citizen: He ran as a candidate for the Senate (the membership of which was open only to Peruvian citizens) and, more importantly, he accepted the office of Consul General to the Netherlands, upon the authorization of both the Peruvian government and the Peruvian Congress. Hence, the tribunal concluded, "whatever Rafael Canevaro's status as a national may be in Italy, the Government of Peru has a right to consider him a Peruvian citizen and to deny his status as an Italian claimant." 458

In the Alexander Tellech claim before the Tripartite (United StatesAustro-Hungarian) Claims Commission in 1928,459 the claimant, a United States national jure soli and an Austrian national jure sanguinis, had resided in Austria for nearly 30 years since age five when his par-

\footnotetext{
454. 5 U.N.R.I.A.A. 327; [1927-1928] Ann. Dig. 299 (No. 195).

455. [1927-1928] Ann. Dig. 299, 300 (No. 195).

456. I Hague Court Reports (Scott) 284 (Perm. Ct. Arb. 1912); 11 U.N.R.I.A.A. 397;

H. Brigcs, supra note 10, at 512 .

457. See, e.g., P. WEIs, supra note 1 , at 173 .

458. H. Brigcs, supra note 10 , at 512 .

459. 6 U.N.R.I.A.A. 248.
} 
ents moved to live in Austria. After being interned "as an agitator engaged in propaganda in favor of Russia," he was drafted into military service by the Austrian government. ${ }^{460}$ The Commission dismissed the United States claim for compensation on Tellech's behalf on the ground that he was a national of Austria as well as of the United States and that he had voluntarily taken "the risk incident to residing in Austrian territory and subjecting himself to the duties and obligations of an Austrian citizen arising under the municipal laws of Austria." 461

In the Merge case, ${ }^{462}$ the claimant possessed the nationality both of the claimant state, the United States, and of the respondent state, Italy. In its opinion, the Italian-United States Conciliation Commission noted the possibility of finding effective nationality in the claimant state in unequivocal terms:

The principle, based on the sovereign equality of States, which excludes diplomatic protection in the case of dual nationality, must yield before the principle of effective nationality whenever such nationality is that of the claiming State. But it must not yield when such predominance is not proved, because the first of these two principles is generally recognized and may constitute a criterion of practical application for the elimination of any possible uncertainty. ${ }^{463}$

After detailed examination of the facts, however, the Commission found that the claimant's family "did not have its habitual residence in the United States and the interests and the permanent professional life of the head of the family were not established there." 464 Hence, it concluded that the claimant "can in no way be considered to be dominantly a United States national." 465

The most dramatic deprivation for a person of multiple nationality relates to the burdens of military service. Intense demands for military service have appeared to be the principal source of frictions between states in their competing claims to control individuals having multiple nationality. Hence, a paramount concern at the 1930 Hague Conference was to alleviate the burdens of "multiple" military service

460. Id. at 249 .

461. Id.

462. Merge Claim, [1955] I.L.R. 443 (Italian-United States Conciliation Commission 1955); 14 U.N.R.I.A.A. 236.

463. [1955] I.L.R. 443, 455 .

464. Id. at 456 .

465. Id. at 457 . 
for people of multiple nationality and thus to help lessen frictions among states. This profound concern found concrete expression in the Protocol Relating to Military Obligations in Certain Cases of Double Nationality adopted at the Conference. ${ }^{406}$ According to the Protocol, a person having multiple nationality "who habitually resides in one of the countries whose nationality he possesses, and who is in fact most closely connected with that country, shall be exempt from all military obligations in the other country or countries." 407 If such a person has the right, under the law of any of these states, "on attaining his majority, to renounce or decline the nationality of that State, he shall be exempt from military service in such State during his minority." 468 If he has lost one nationality and acquired another, he "shall be exempt from military obligations in the State of which he has lost the nationality." 469

Elaborate provisions regarding military obligations are found in the European Convention on Reduction of Cases of Multiple Nationality and Military Obligations in Cases of Multiple Nationality. ${ }^{470}$ "Persons possessing the nationality of two or more Contracting Parties shall be required to fulfill their military obligations in relation to one of those Parties only," under special arrangements to be made between any of the contracting states. ${ }^{471}$

466. The Protocol was signed at the Hague on April 12, 1930, 178 L.N.T.S. 227.

467. Id. at 229 (Art. 1).

468. Id. at 231 (Art. 2).

469. Id. (Art. 3).

470. Europ. T.S. No. 43 (1963).

471. Id. at 4. Pursuant to article 6 , in the absence of a special agreement, the following provisions are applicable to a person possessing the nationality of two or more Contracting Parties:

1. Any such person shall be subject to military obligations in relation to the Party in whose territory he is ordinarily resident. Nevertheless, he shall be free to choose, up to the age of 19 years, to submit himself to military obligations as a volunteer in relation to any other Party of which he is also a national for a total and effective period at least equal to that of the active military service required by the former Party.

2. A person who is ordinarily resident in the territory of a Contracting Party of which he is not a national or in that of a State which is not a Party may choose to perform his military service in the territory of any Contracting Party of which he is a national.

3. A person who, in accordance with the rules laid down in paragraphs 1 and 2 , shall fulfil his military obligations in relation to one Party, as prescribed by the law of that Party, shall be deemed to have fulfilled his military obligations in relation to any other Party or Parties of which he is also a national.

4. A person who, before the entry into force of this Convention between the Parties of which he is a national, has, in relation to one of those Parties, fulfilled his military obligations in accordance with the law of that Party, shall be deemed to have fulfilled the same obligations in relation to any other Party or Parties of which he is also a national.

5. A person who, in conformity with paragraph 1 , has performed his active military service in relation to one of the Contracting Parties of which he is a national, and subsequently transfers his ordinary residence to the territory of the 
With the exception of military obligations, there is little, in terms of amelioration of value deprivations for people of multiple nationality, comparable in scope to the treatment accorded to stateless persons. Treaties are sometimes concluded to eliminate or reduce double taxation. ${ }^{472}$ Mention may also be made of article 3 of the European Convention on Reduction of Cases of Multiple Nationality which states:

The Contracting Party whose nationality a person desires to renounce shall not require the payment of any special tax or charge in the event of such renunciation. ${ }^{473}$

From this brief survey it can be seen that the efforts of states both to minimize the occurrence of multiple nationality and to provide ameliorations for the burdens it imposes are far from adequate. The individual is still not given full opportunity to choose between retention of multiple nationality or renunciation of nationalities which may impose burdens upon him incompatible with human rights. Multilateral conventions might be devised which would afford individuals more freedom of choice in the retention of benefits and in the renunciation of burdens, when such renunciation is not inimical to an appropriate community responsibility. Certainly the traditional doctrine that one state cannot protect an individual against another state of his nationality should be abandoned. It can only serve to deny human rights and to exaggerate state interests at the expense of the individual. The appropriate amelioration of burdens with respect to other values must of course depend upon many variables in the context in which such values are pursued.

\section{Appraisal and Recommendations}

The fundamental problem with which we have been concerned is that of how the individual secures access to arenas of authoritative decision external to his own state for the vindication of his basic, substantive rights. Ancillary problems relate to the humanity with which the laws of nationality are shaped for affecting this access to protection

other Party of which he is a national, shall be liable to military service in the reserve only in relation to the latter Party.

6. The application of this Article shall not prejudice, in any respect, the nationality of the persons concerned.

7 . In the event of mobilisation by any Party, the obligations arising under this Id. Article shall not be binding upon that Party.

472. See S. Greenleigh \& R. Margenau, supra note 1, at 412-14.

473. Europ. T.S. No. 43, at 3 (1963). 
and for determining which state may subject the individual to the community burdens of military service, taxation, expropriation, and criminal and civil jurisdiction. The basic, substantive rights which the individual may seek to vindicate are now importantly clarified and articulated in all the emerging human rights prescriptions. The myth, however, is still far too prevalent that the individual is not an appropriate subject of international law for the protection of these rights ${ }^{474}$ and must have a special protector in the form of a state of nationality. It is through "nationality" only that the individual acquires much of what access he has to transnational processes of authoritative decision. Hence, it remains important to appraise trends in the degree to which the laws of nationality do afford the individual the necessary protection and other human rights and to consider alternatives for improvement in the protection of all rights.

Some modest movement toward human rights may be observed, as our summaries indicate, in the laws concerning conferment and withdrawal of nationality. In terms of conferment of nationality, there has been a widening use of both jus soli and jus sanguinis to ensure that an individual is born with at least one nationality. There has been some obvious loosening of rigorous requirements, at least for certain categories of people, for facilitating acquisition of nationality subsequent to birth. The imposition of nationality upon individuals without their consent is commonly regarded as contrary to international law. The right to change nationality, notably the right of voluntary expatriation, has been increasingly recognized in general community expectation as a fundamental human right. In regard to withdrawal of nationality based on imputed consent, decisionmakers appear in: creasingly to require a genuine consent or a close relation to important policies in the maintenance of harmonious relations between states. There is a growing expectation, further, that denationalization as a punishment, having no necessary relation to the maintenance of harmonious relations between states, is cruel and inhumane and, hence, unlawful. In particular, there appears to be an emerging peremptory norm of nondiscrimination which would outlaw denationalization upon

474. For a general survey of views about the role of the individual in international law, see P. JEssup, supra note 74, at 15-26; H. LAUTERPACHT, supra note 126, at 3-72; C. NorgaArd, The Position of the Individual in INTERnational LaW (1966); L. Sohn \& T. Buergenthal, International Protection of Human Rights I-2l (1973); J. Jefferies, The Individual and International Law, 1954 (unpublished J.S.D. dissertation, Yale Law School); Amon, The Individual in International Law, 13 FAR EASTERN L. REv. 185 (1966); Manner, The Object Theory of the Individual in International Law, 46 AM. I. INT'L L. 428 (1952); Tucker, Has the Individual Become the Subject of International Law?, 34 U. CIN. L. Rev. 341 (1965). 
racial or ethnic grounds. Many prescriptions have been enunciated both to minimize the occurrence of statelessness and to ameliorate the treatment accorded to stateless persons. ${ }^{475}$ More limited progress has been made in measures to minimize the occurrence of multiple nationality and to lessen the burdens imposed upon people possessing multiple nationality.

The flow of state decisions about nationality and the regime of international regulation continue, however, to disregard important human rights criteria, particularly with respect to affording the individual real choice. Nationality is conferred on a person at birth by jus soli, $j u$ sanguinis, or both; nationality is, further, sometimes thrust upon him subsequent to birth without his consent. States are not required to confer nationality upon any set of specified grounds and the requirements and procedures even for accepted grounds are often arbitrary. All too often the individual is allowed to change nationality only with the consent of the state from which he seeks to escape. Conversely, the individual may still have his nationality arbitrarily taken from him. The withdrawal of nationality may be based on largely fictitious consent and may have little relation to maintaining harmonious relations between states. Deprivation of nationality is still used as a form of punishment for political or other reasons. Insufficient effort has been made to rectify the diversities in state laws that have the consequence of rendering many stateless; individuals may thus still find themselves without a nationality and unable to obtain one. Finally, the international law of multiple nationality remains largely designed to protect state, and not individual, interests; many individuals continue to find themselves subject to multiple burdens, but without protection against a most important category of deprivors, states of their nationality. ${ }^{478}$

475. We are aware that the mere enunciation of prescriptions may not serve to protect the human rights of people, but we do regard such enunciation as an indispensable first step toward protection. When policies are clarified and predispositions toward conformity mobilized, the potentialities for enforcement are increased. In evidence we would submit the general community experience with the Universal Declaration of Human Rights.

476. Our review of the doctrines and procedures connected with the traditional notion of nationality has spotlighted yet another sector of the vast corpus of international law that won acceptance in an historical setting where the dominant task was to find workable ways of resolving occasions for friction among members of the largely European world state system. The established myth was understood to impose no obligation on a state to act for the protection or assistance of nationals who advanced a claim on another state. By abstaining from intervention in these circumstances a state was in a position to avoid a potentially irritating confrontation with other states. At the same time, if the target state was politically weak and isolated, and especially if it sought to apply non-European prescriptions to its internal affairs, a 
The first and most fundamental recommendation we would make is that individuals be authorized to protect themselves. The substantive human rights prescriptions can never be made effective if the individual human being is not himself accorded competence to invoke them under appropriate conditions. The individual should be made a full subject of international law, with that access to all arenas, both international and national, which is necessary for him to protect himself.

Given continued state priority and domination, a second recommendation is that much greater effect be given, in the laws permitted by international law for the conferment or withdrawal of nationality, to the free choice of the individual in associating himself with a state. A most important move in this direction would be to accord the individual, contrary to the holding in the Nottebohm decision, a freedom of choice among potential state protectors. If the individual is able to find a state willing and able to protect him, with or without pecuniary inducement, that state should be authorized to protect him. ${ }^{477}$ This change could easily be effected by a presumption of the validity of a certification of nationality for purposes of suit.

A third recommendation is some centralization, or organized inter-

European state could champion the claims of its nationals with great vigor, and with minimum risk of loss.

The world situation has changed and will continue to change in ways that affect the flow of transactions among states. In many parts of the globe the number of individuals whose value indulgences and deprivations are affected by transnational activities has greatly multiplied. These new participants in world community process are sensitive to the failures of their own state, or of other states, to act on behalf of the integrity of the growing system of involvement. In recent years a body of demand and expectation has steadily intensified on behalf of doctrines and procedures that might fill the conspicuous gaps that were left in the prevailing order. These new perspectives identify much more extensively than before with the rights of individual human beings. This carries with it a series of changes that are at present in full course of evolution, and to which we seek to contribute both by redefining the conceptions and operations referred to by the rubric of nationality and by suggesting new institutional practices and procedures.

477. The Convention on the Prevention and Punishment of Crimes against Internationally Protected Persons, including Diplomatic Agents (U.N. Doc. A/RES/3166 (XXVIII) of 5 February 1974, reprinted in 13 I.L.M1. 41 (1974)), which was adopted by the United Nations General Assembly and open for signature on February 5, 1974, would appear to make an important advance in this direction. Article 6(2)(a) provides that an alleged offender, "if he is a stateless person," shall be entitled "to communicate without delay with the nearest appropriate representative of the State . . . which he requests and which is willing to protect his rights." 13 I.L.M. 46 (1974).

The recommendation we make for ameliorating the condition of stateless persons and persons possessing multiple nationality with respect to all values is simply that they be accorded basic human rights as formulated in contemporary prescriptions. Apart from nationality problems, their problems are the same as those of people having one nationality: They share all the same demands, identifications, and expectations and are subject to all the same finite limitations. For an excellent statement of this perspective, see Kellogg, Refugees and Human Rights: The Path Ahead, 69 Der'T STATE BuLL. 375 (1973). 
nationalization, of the protection function on the global level. A relatively unorganized internationalization of the function would be to permit states to volunteer to protect individuals, somewhat in the fashion provided for signatories of the European Convention on $\mathrm{Hu}$ man Rights. ${ }^{478}$ A more organized form would be a centralized international ombudsman within the framework of the United Nations.

The concept of "United Nations citizenship" might be given substance by a specialized United Nations agency for the protection of the disfranchised people of the world. The establishment "within the framework of the United Nations" of "a body" to which a stateless person "may apply for the examination of his claim and for assistance in presenting it to the appropriate authority," as envisaged in article 11 of the Convention on the Reduction of Statelessness, ${ }^{479}$ together with the experience of the Office of the United Nations High Commissioner for Refugees (UNHCR) in protecting and assisting refugees (especially in helping them obtain identity papers and travel documents from governments concerned ${ }^{480}$ ), may suggest the rudiments of a model that could be expanded and improved. Instead of merely using its good offices to secure the cooperation of national governments and leaving the ultimate decision in these governments, as is presently the case with the Office of UNHCR, ${ }^{481}$ the proposed U.N. agency could be empowered to confer, under its own authority, "world citizenship" (a "United Nations citizenship") upon individuals and thus itself perform the necessary protective function. Pending the achievement of a world commonwealth of free persons in open frontiers, United Nations citizenship could be made to coexist with the existing nationalities of states. All human beings should be eligible-

478. The reference is to the state-to-state complaint system developed under article 24 of the European Convention on Human Rights. Under this provision a contracting state may refer to the European Commission of Human Rights alleged violations of the Convention, regarding not only its own nationals, but also nonnationals. See CounCIL of Eurole, THE European Convention on HuMan Rights 12-13 (1968); European Commission of Human Rights, Stock-Taking on the European Convention on Human Rights (DH (72) 7) 4.11 (1972); A. RoBertson, HuMAN Rights IN EUROPE 58.62 (1963); L. SOHN \& T. BUERGENTHAL, supra note 474, at 1050-90; Fawcett, supra note 279, at 275-77. Also relevant are the state-to-state complaint systems embodied under article 11 of the International Convention on the Elimination of All Forms of Racial Discrimination and article 41 of the International Covenant on Civil and Political Rights. U.N. HUMAN RIGHTS INSTRUMENTS, supra note 70, at 25-26, and 14 respectively.

479. U.N. HUMAN Rights InstrumenTs, supra note 70, at 56.

480. See articles 27 and 28 of the Convention Relating to the Status of Refugees,

U.N. HuMAN Rights INSTRUMENTS, supra note 70, at 67-68.

481. Identity papers and travel documents are issued by the respective governments of the contracting parties to the Refugee Convention or to the Protocol to the Refugee Convention, not by the Office of the United Nations High Commissioner for Refugees. The Office of the UNHCR is not empowered to do so. 
whether out of necessity or out of choice-for such United Nations citizenship.

Nationality is a concept created in the past to promote a minimum organization of the world under past conditions. The reference and function of the concept cannot remain static: It must be as dynamic as the changing demands and identifications of peoples and the changing configuration of the world and national constitutive processes. In the words of the Harvard Research on the Law of Nationality,

Nationality has no positive, immutable meaning. On the contrary its meaning and import have changed with the changing character of states. Thus nationality in the feudal period differed essentially from nationality, or what corresponded to it, in earlier times before states had become established within definite territorial limits, and it differs now from what it was in the feudal period. It may acquire a new meaning in the future as the result of further changes in the character of human society and developments in international organization. ${ }^{482}$

As human beings seek greater fulfilment of all values, through ever increasing transnational interactions and ever more frequent mobility, in a world of intimate interdependences and the universalizing culture of science and technology, nationality must be made to serve the development and happiness of human beings, and not to perpetuate human bondage by anchoring people, against their will, in a particular territorial community or alternatively casting them adrift when it is withdrawn. The time has come to make the law of nationality defend and fulfill the human rights of the individual.

482. Harvard Research, supra note 1, at 21. 